\title{
EMPLOYABILITY van UM-afgestudeerden
}

Citation for published version (APA):

van Eldert, P., Künn, A., \& Mommers, A. (2017). EMPLOYABILITY van UM-afgestudeerden. ROA. ROA Reports No. 003 https://doi.org/10.26481/umarep.2017003

Document status and date:

Published: 01/01/2017

DOI:

10.26481/umarep.2017003

Document Version:

Publisher's PDF, also known as Version of record

\section{Please check the document version of this publication:}

- A submitted manuscript is the version of the article upon submission and before peer-review. There can be important differences between the submitted version and the official published version of record.

People interested in the research are advised to contact the author for the final version of the publication, or visit the DOI to the publisher's website.

- The final author version and the galley proof are versions of the publication after peer review.

- The final published version features the final layout of the paper including the volume, issue and page numbers.

Link to publication

\footnotetext{
General rights rights.

- You may freely distribute the URL identifying the publication in the public portal. please follow below link for the End User Agreement:

www.umlib.nl/taverne-license

Take down policy

If you believe that this document breaches copyright please contact us at:

repository@maastrichtuniversity.nl

providing details and we will investigate your claim.
}

Copyright and moral rights for the publications made accessible in the public portal are retained by the authors and/or other copyright owners and it is a condition of accessing publications that users recognise and abide by the legal requirements associated with these

- Users may download and print one copy of any publication from the public portal for the purpose of private study or research.

- You may not further distribute the material or use it for any profit-making activity or commercial gain

If the publication is distributed under the terms of Article $25 \mathrm{fa}$ of the Dutch Copyright Act, indicated by the "Taverne" license above, 
Research Centre for Education and the Labour Market | ROA

\section{EMPLOYABILITY van UM-afgestudeerden}

\section{ROA Rapport}

ROA-R-2017/3

Researchcentrum voor Onderwijs en Arbeidsmarkt | ROA Research Centre for Education and the Labour Market / ROA 


\section{EMPLOYABILITY VAN UM-AFGESTUDEERDEN}

ROA-R-2017/3

Peter van Eldert

Annemarie Künn-Nelen

Ardi Mommers 


\section{Colofon}

(C) Researchcentrum voor Onderwijs en Arbeidsmarkt (ROA). Niets uit deze uitgave mag op enige manier worden verveelvoudigd zonder voorafgaande schriftelijke toestemming van de directeur van het ROA.

\section{Researchcentrum voor Onderwijs en Arbeidsmarkt}

School of Business and Economics

Maastricht University

email: secretary-roa-sbe@maastrichtuniversity.nl

website: www.roa.nl

\section{Vormgeving}

ROA secretariaat, Maastricht

ISBN: 978-90-5321-555-5

april 2017 


\section{INHOUD}

$\begin{array}{lr}\text { Voorwoord } & \text { i } \\ \text { English summary } & \text { iii } \\ \text { Samenvatting } & \text { ix }\end{array}$

01 Inleiding 1

02 Literatuur 3

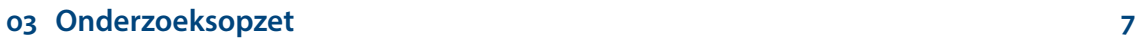

$\begin{array}{ll}3.1 & \text { Databronnen } \\ & 7\end{array}$

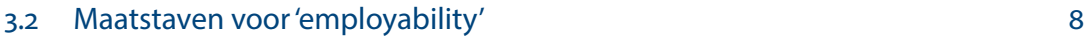

$\begin{array}{ll}3.3 & \text { Onderscheiden faculteiten } \\ & 10\end{array}$

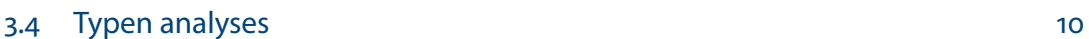

04 Employability van UM afgestudeerden in kaart gebracht 11

4.1 Werkloosheid 11

4.2 Baan op universitair niveau 13

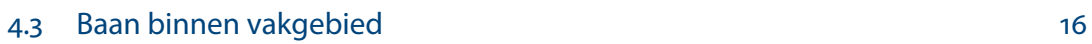

$\begin{array}{ll}\text { 4.4 Vaste baan } & 18\end{array}$

$\begin{array}{ll}\text { 4.5 } & \text { Relatief hoog inkomen } \\ & 21\end{array}$

4.6 Tevredenheid huidige functie 23

4.7 Carrièremogelijkheden huidige functie 25

4.8 Employability indicatoren per faculteit 27

4.9 Employability indicatoren naar master opleiding 28

05 Employability van UM afgestudeerden verklaard 35

5.1 De rol van persoonsfactoren en faculteit 35

5.2 De rol van persoonsfactoren en opleidingen 40

5.3 De rol van persoonlijkheid, competenties en wo-instelling 44

06 Conclusies en discussie $\quad 51$

6.1 Conclusies 51

6.2 Discussie 55 
Literatuur

Bijlage 


\section{VOORWOORD}

De voor u liggende studie is een weerslag van het project 'Employability onder UM afgestudeerden'. Het rapport geeft eerst een samenvatting van de uitgevoerde literatuurstudie op het gebied van 'employability' in het hoger onderwijs. Vervolgens wordt de 'employability' van UM afgestudeerden vijf jaar na afstuderen anno 2015 in kaart gebracht. Hiertoe rapporteren we zeven indicatoren voor 'employability'. Naast de gebruikelijke UM brede en faculteitsspecifieke statistieken laten we ook statistieken per masteropleiding zien. Vervolgens wordt beschreven hoe de 'employability' van UM afgestudeerden zich de afgelopen 15 jaar ontwikkeld heeft, voor de UM in het geheel als ook voor de verschillende faculteiten. Voor afzonderlijke HOOP-sectoren wordt vervolgens gekeken in hoeverre UM afgestudeerden anders scoren op de zeven 'employability' indicatoren dan afgestudeerden van andere Nederlandse universiteiten tesamen. In het derde deel van dit rapport wordt bekeken wat de voorspellers van succes zijn. We onderscheiden hierbij persoonsfactoren, persoonlijkheid, opleiding en faculteit en een veertiental competenties gemeten vijf jaar na afstuderen.

De belangrijke conclusies op basis van het rapport zijn:

- De 'employability' literatuur is vaak theoretisch van aard, waardoor uitspraken over 'effectiviteit' of 'nut' moeilijk te doen zijn

- De 'employability' van SBE en FdR afgestudeerden is bovengemiddeld

- De'employability' op UM niveau is over de tijd vrij stabiel, en op faculteitsniveau wat grilliger

- De verschillen tussen 'employability'van UM en andere Nederlandse afgestudeerden zijn gering

- De 'employability' van UM afgestudeerden wordt gedeeltelijk verklaard door persoonskenmerken, persoonlijkheid en opleiding

In het slothoofdstuk worden op basis van deze conclusies nog aanbevelingen gedaan voor vervolgonderzoek.

Prof. Dr. Rolf van der Velden 


\section{ENGLISH SUMMARY}

Usually literature focusses on the theoretical character of employability, which makes it hard to form any conclusions in terms of 'effectivity' and 'purpose'.

There are several definitions of the concept employability, which usually look similar, but with different approaches. What they do have in common is the notion that employability has something to do which the labour market and work. The definitions of employability can roughly be organized on an orientation scale from 'considerably individualistic' to 'considerably contextual'. This implies: either strongly focussed on individual differences in terms of competencies and characteristics (one is more employable when one has better competencies), or strongly focussed on the labour market situation (one's employability grows when demand exceeds supply). If we presume a more subtle form, the notion that the employability of students and graduates is determined by both individual characteristics and contextual features, we can differentiate between three types of factors that define employability: individual factors, educational and institutional factors and labour market factors.

It is possible to define two types of indicators to measure employability, objective and subjective indicators. Objective indicators can be defined as 'hard' labour market outcomes. These indicators are related to finding employment, and if so, to job conditions and job tasks. With subjective indicators the emphasis is on the assessment of personal competences that are considered useful on the labour market, often referred to as 'employability skills'. This concerns for example personality traits such as eagerness to learn and flexibility, but also more concrete competences such as teamwork, communication etcetera. There are also subjective indicators that do identify the direct relation between the current job and the labour market like the extent to which the current job matches competencies and the job satisfaction.

Even though higher education is, in recent years, paying more attention to the development of 'employability skills' of students, there is no empirical evidence showing that graduates from schools with a higher focus on the development of 'employability skills' are more attractive on the labour market. It has to be kept in mind though that most studies focused on short-term effects. Nevertheless, this literature review indicates that there are possible improvements on other fronts of the curriculum. Students who did an internship have for example a higher probability to find a job. Furthermore the construc- 
tion of studies by both education and the business world are suggested to improve the perspectives of the students.

Summarizing, one could state that the employability literature is mainly theoretical, which makes it hard to form any conclusions in terms of 'effectiveness' and 'usefulness'. In the future it seems to be important to study employability empirically. This study can be a first step in this.

\section{Employability SBE and FdR graduates above average}

In this study, employability is measured by seven indicators: unemployment, working at university level, working in own domain, permanent contract, relatively high paying job, job satisfaction and career perspectives within the current job. The data at hand make it possible to differentiate between five faculties: SBE, FHML, FASOS, FPN and FdR. There is not one faculty that outperforms the others on all employability indicators. Yet two faculties stand out with relatively high scores for most of the indicators. One of them is SBE scoring the best on the probability of finding a job, having a permanent contract, having a job with a relatively high salary and having a more positive judgement of their own career perspectives. They also score high concerning job satisfaction and finding a job at university level. FdR tops the other faculties in terms of employment, university level jobs, permanent contract, and relatively high incomes. Furthermore they score average on finding a job within their own domain, job satisfaction and career perspectives. Within these two faculties there is not a master programme that clearly outperforms the others, it really depends on the indicator one focusses on. Econometrics and operations research graduates score best on working in their own domain, finding a job at university level, job satisfaction and career perspectives, but score lower than other SBE studies in terms of salary. Within FdR, graduates from European Law School score relatively well with respect to unemployment, working in their own domain and finding a job at university level. However they score considerably lower on the probability of having a permanent contract, relatively high incomes, job satisfaction and career perspectives. The master Globalisation and law scores, five years after graduation, relatively bad on most employability indicators compared to the other masters at FdR.

The scores of FHML graduates vary considerably between the employability indicators, for some they score relatively high while for other indicators relatively low scores are found. FHML graduates score best on job satisfaction, work relatively often in their own domain, and are relative positive about their own career perspectives. In contrast, the unemployment rate is relatively high $(5.2 \%)$ and also the probabilities to find a job at university level and a high paying job are small compared to other faculties. It should be noted however that Medicine highly influences the scores because of their extreme values, both positive and negative. For example, all graduates from Medicine are working in their own domain and have an academic levelled job. At the same time, the probability that graduates of FHML have a permanent contract is dragged down by a low percentage of Medicine. 
Graduates of FPN have the highest probability of a job at university level and in their own domain. However, it is less likely that they have a permanent contract and they are less positive in terms of job satisfaction and career perspectives. They score average compared to the other faculties with respect to unemployment and relatively high incomes.

There clearly is room for improvement among FASoS graduates with respect to the employability indicators presented in this report. Compared to the other faculties they have the highest probability of being unemployed and the lowest probability to have a job at univeristy level, to work in their own domain, to gain a relatively high income, to be satisfied with their current job, and to perceive good career perspectives. However, in absolute terms, an unemployment rate among graduates of $6.7 \%$ five years after graduation can still be classified as a decent result. Among those who do have a job, more than three quarters of them find one at university level. Nevertheless, the employability of FASOS graduates as measured by the seven indicators used in this study, seems less than graduates from other faculties within the UM.

However, some remarks have to be raised:

- In this report we summarize the employability of UM graduates on the basis of indicators which stand out from the literature and which are included in the data of UM graduates.

- Given the available UM data on graduates 5 and 10 years after graduation it is not possible to define other employability indicators.

- However, students and graduates (of specific faculties) might value other aspects of employability more than the seven indicators used in this report. It seems important to include more employability questions dealing with lifelong learning (becoming more productive) and with the perception of graduates on the ease to find a comparable job in case of the unexpected event of losing their job. After all, students at UM are not solely educated to graduate as fast as possible but also to be able to grow and adapt in their further career (Bastiaens \& Muijsers 2016).

Employability over time: stable at UM level, fluctuating at faculty level

In general the employability indicators are quite stable among UM graduates. Obviously unemployment is highly correlated with the economic climate resulting in a peak in 2010. The probability of finding a job at university level has been increasing progressively since 2001. The percentage of UM graduates working at university level was $20 \%$-point higher in 2015 compared to 2001. Approximately 80\% of all UM graduates work five years after graduation in their own domain, a percentage that has been quite stable over the last 15 years. What has been decreasing recently is the probability of getting a permanent contract. This is in line with the current flexibilization of the labour market in the Netherlands, which means that is not a phenomenon specific to UM graduates. The probability of finding a relatively high paying job has decreased the last 15 years, with the exception of a little increase between 2005 and 2009. This little increase has also been observed at other educational levels which again implies that the phenomenon is 
not specific to UM. Job satisfaction has been considerably stable although between 2012 and 2015 less than three quarters of the UM graduates was satisfied with their current job. Concerning their own perception about their career perspectives UM graduates are becoming less positive during the recent years.

As it turns out trends of the underlying faculties do not show similarities to the overall trend of UM. Even though it is observed that FHML and SBE show rather stable patterns, the scores from FdR graduates have been fluctuating over time.

\section{Differences between the employability of UM graduates and graduates from other universities are slim}

The best way to compare graduates from UM and other universities is to differentiate between the different HOOP areas. In general there are just minor differences, but there are a few interesting differences worth noting. For example the share of graduates with a job at university level is much higher among UM graduates compared to graduates from other Dutch universities when we focus on the HOOP areas economics and behaviour. UM graduates are less likely to find a permanent contract within the areas behaviour and law, compared to those from other Dutch universities. Side note to this observation is the fact that a large share of UM graduates does not have a Dutch nationality which means that they might be dealing with different labour market situations when they return to their own country after graduation. Within the healthcare sector UM graduates, in contrast to graduates from other Dutch universities, turn out to have higher chance to find a job with a relatively high income. In terms of job satisfaction, we only observe differences between UM and other graduates in the HOOP area behaviour.

\section{Employability of UM graduates explained by background characteristics, personality and educational program}

The analyses reveal a number of determinants of the employability indicators. First of all, women are compared to men less likely to find a job at university level and earn a lower salary. These correlations are larger 10 years after graduation compared to five years after graduation. Furthermore graduates born outside of the Netherlands turn out to be generally more 'employable'. They are more likely to find a job at university level and to find a job in their own domain. Moreover they also have a higher probability to get a permanent contract 10 years after graduation. However, we have to keep in mind that there might be selection effects in terms of nationality. It could be the case that $\mathrm{UM}$ is only attracting the better performing foreign students. Furthermore, other nationalities do not necessarily enter the Dutch labour market, when they return to their home country in which they will face different labour market conditions. In contrast to the positive scores on the above mentioned employability indicators, the non-Dutch graduates score lower in terms of job satisfaction and career perspectives. PhD graduates benefit from acquiring a doctoral degree in terms of a higher probability to find a job at academic level and in their own domain, but permanent contracts and relatively high incomes are less likely. In the meantime they have a higher probability to have good career perspectives. 
Job satisfaction and own perception on career perspectives among graduates is very dependent on the more objective measures of employability. One is more likely to be satisfied with their job when one is working within the own domain and when one has a job at university level. Career perspectives are driven by the required job level and by salary. Furthermore graduates with a permanent contract tend to be more positive about their career perspectives. The differences at faculty and study program level found in the descriptive statistics are highly consistent with the results from the empirical analyses.

In the final set of analyses, seven universities were analysed together to find out whether personality determinants employability. Four personality factors turn out to correlate with employability. Firstly, extravert graduates are more satisfied with their jobs but are less likely to get a permanent contract. More forward looking graduates are less likely to get a permanent contract and are payed less. Furthermore, job satisfaction turn out to be higher among graduates who are more targeted towards service. Finally, risk loving graduates are more positive about their own career perspectives. 



\section{SAMENVATTING}

'Employability' literatuur is vaak theoretisch van aard, waardoor uitspraken over 'effectiviteit' of 'nut' moeilijk te doen zijn.

Er bestaan talloze definities van het concept 'employability' die meestal op elkaar lijken, maar vaak nét een iets andere insteek hebben. Wat ze met elkaar gemeen hebben, is dat 'employability' in ieder geval altijd iets te maken heeft met de arbeidsmarkt en werk. Ruwweg zijn de definities van 'employability' te ordenen zijn op een schaal van 'zeer individualistisch' tot 'zeer contextueel' georiënteerd. Dat wil zeggen: ofwel sterk gericht op individuele verschillen in competenties en eigenschappen (indien men over betere competenties beschikt, is men meer 'employable'), ofwel sterk gericht op de arbeidsmarktsituatie (indien de vraag het aanbod overstijgt, groeit iemands 'employability'). Als we uitgaan van een meer gangbare 'tussenvorm', namelijk dat de 'employability' van studenten/afgestudeerden zowel wordt bepaald door individuele eigenschappen alsook contextuele kenmerken, kunnen we in ieder geval drie typen factoren onderscheiden die een rol spelen bij 'employability'. Individuele factoren, opleidings- en instellingsspecifieke factoren en arbeidsmarktfactoren.

Ruwweg zijn er twee typen indicatoren te onderscheiden om 'employability' te meten, objectieve indicatoren en subjectieve indicatoren. Bij de objectieve indicatoren gaat het om 'harde' arbeidsmarktuitkomsten. Deze indicatoren hebben te maken met het al dan niet vinden van werk, en indien men werk heeft met de arbeidsvoorwaarden en de functie-inhoudelijke aspecten. Bij 'subjectieve indicatoren' ligt de nadruk vooral op het beoordelen van persoonlijke competenties die nuttig geacht worden op de arbeidsmarkt, vaak ook wel 'employability skills' genoemd. Het gaat dan bijvoorbeeld om 'scores' op karakteristieken zoals leergierigheid of flexibiliteit, maar ook om meer concrete competenties zoals teamwork, communicatie en dergelijke. Daarnaast zijn er nog subjectieve indicatoren die wèl een directe relatie leggen met de baan en dus met de arbeidsmarktsituatie. Voorbeelden zijn de mate waarin de huidige baan aansluit op de competenties van personen en baantevredenheid.

Hoewel het hoger onderwijs door de loop van de jaren steeds meer aandacht is gaan schenken aan het ontwikkelen van 'employability' skills van studenten is er geen sterke empirische onderbouwing gevonden dat de 'employability' van afgestudeerden afkomstig van opleidingen met een sterke aandacht voor die competenties kansrijker zijn 
op de arbeidsmarkt. Hierbij moet wel rekening gehouden worden dat de studies zich alleen hebben gericht op de kortetermijneffecten. Waar wel goede aanwijzingen voor zijn, is de bijdrage van praktijkrelevantie in het onderwijs. Zo hebben studenten met een beroepsstage bijvoorbeeld een grotere kans op werk. Verder zijn er aanwijzingen dat opleidingen waarin het onderwijs samen met het bedrijfsleven wordt inrichten, betere perspectieven bieden voor hun studenten.

Samengevat kan men stellen dat de 'employability' literatuur vaak theoretisch van aard is, waardoor uitspraken over 'effectiviteit' of 'nut' moeilijk te doen zijn. Het lijkt dan ook zinvol om het fenomeen 'employability' in de toekomst meer vanuit een empirische bril te bezien. De voorliggende studie is daar een mooi voorbeeld van.

\section{'Employability' van SBE en FdR afgestudeerden bovengemiddeld}

In deze studie is 'employability' gemeten op basis van zeven indicatoren: werkloosheid, baan op universitair niveau, baan binnen vakgebied, vaste baan, relatief hoog inkomen, tevredenheid huidige funcie en carrieremogelijkheden huidige functie. Het is gegeven de data mogelijk om de volgende vijf faculteiten te onderscheiden: SBE, FHML, FASoS, FPN en FdR. Er is niet één faculteit die op alle zeven 'employability' indicatoren het hoogste scoort. Toch springen er twee faculteiten uit die het op de meeste gebieden relatief goed doen. Zo scoort SBE het beste op de kans op werk, op een vaste baan, op een baan met een relatief hoog inkomen en op geschatte carrièremogelijkheden. Wat betreft baantevredenheid en een baan op wo-niveau scoren ze ook in de top. FdR staat vergeleken met andere faculteiten ook ver bovenaan met betrekking tot werkloosheid, wo-niveau, vaste baan en relatief hoog inkomen. Daarnaast scoren ze gemiddeld op een baan binnen het vakgebied en op baantevredenheid en carrièremogelijkheden. Het is niet eenvoudig binnen deze faculteiten masteropleidingen aan te wijzen die duidelijk beter scoren dan andere. Dit hangt enorm af van de indicator. Zo doet de specialisatie finance van IB het ten opzichte van de andere SBE masters erg goed op zes van de zeven indicatoren, maar hebben afgestudeerden binnen finance wel de laagste kans op een baan binnen het vakgebied. Het is vervolgens aan ieder individu an sich om te bepalen welke indicatoren het belangrijkste zijn. Zo doet binnen FdR de European Law School het relatief goed met betrekking tot werkloosheid, werken in het vakgebied en werken op wo-niveau. Echter, de kans op een vaste baan of een baan met een relatief hoog inkomen zijn relatief laag. Ook zijn afgestudeerden van deze master relatief minder vaak tevreden met hun huidige baan en met de carrieremogelijkheden. De master globalisation and law is een master die het in vergelijking tot andere masters binnen FdR relatief slecht doet op de hier beschreven indicatoren van 'employability'.

Afgestudeerden van FHML scoren met betrekking tot sommige 'employability' indicatoren relatief hoog, en voor andere juist weer relatief laag. Ze scoren het hoogste op baantevredenheid en werken ook relatief vaak in hun vakgebied (plaats 2) en ze zijn relatief vaak positief over hun carrièremogelijkheden (plaats 2). Echter, het werkloosheidspercentage is met 5,2\% wel relatief hoog en ook is de kans op een baan op wo-niveau als ook de kans op een baan met een relatief hoog salaris juist weer laag vergeleken 
met andere faculteiten. De lage kans op een vaste baan is te wijten aan de vervolgopleidingen binnen FdG en zegt daarmee niet echt iets over 'employability'. De master physical activity and health scoort over het algemeen laag vergeleken met andere masters binnen FHML.

Afgestudeerden van FPN hebben de hoogste kans op een baan op wo-niveau en op een baan binnen het vakgebied. Echter, de kans op een vaste baan is relatief laag en dit geldt ook voor baantevredenheid en carrièremogelijkheden (plaats 4). Met betrekking tot werkloosheid en een relatief hoog inkomen zitten ze precies in het midden vergeleken met andere faculteiten.

Bij de afgestudeerden van FASoS is er duidelijk nog ruimte tot verbetering met betrekking tot de 'employability' indicatoren zoals vastgelegd in deze studie. De kans op werkloosheid, op een baan op wo-niveau, op een baan binnen het vakgebied, op een baan met een relatief hoog inkomen, op een baan waarmee ze tevreden zijn en op een baan met goede carrièremogelijkheden scoren ze het laagste vergeleken met de andere faculteiten. Echter, ook voor deze groep afgestudeerden geldt dat slechts 6,7\% vijf jaar na afstuderen werkloos is. Onder de werkenden geldt dat meer dan drie kwart een baan op wo-niveau heeft. Toch zijn de vooruitzichten voor FASoS afgestudeerden, zeker vergeleken met afgestudeerden van andere faculteiten, niet gunstig.

Echter, een aantal opmerkingen moeten geplaatst worden:

- In dit rapport vatten we 'employability' van UM afgestudeerden samen aan de hand van indicatoren die in 'employability' literatuur bekend staan als belangrijk én die onderdeel uitmaken van de data over UM afgestudeerden.

- Gegeven de UM data over afgestudeerden 5 en 10 jaar na afstuderen is het niet mogelijk om nog meer 'employability' indicatoren te onderscheiden.

- Echter, misschien hechten studenten en afgestudeerden (van specifieke faculteiten) waarde aan andere 'employability' indicatoren dan degene die in deze rapportage aan bod zijn gekomen. Het lijkt in ieder geval zinvol om meer 'employability' vragen mee te nemen die ingaan op een levenlang leren (productiever worden), en de eigen perceptie als het gaat om het verkrijgen van een vergelijkbare baan indien men onverwacht op zoek zou moeten naar een (andere) baan. De UM leidt haar studenten immers niet alleen op om zo snel mogelijk na afstuderen een baan te vinden, maar ook om te zorgen voor continue groei en aanpassingsmogelijkheden (Bastiaens \& Muijsers 2016).

\section{‘Employability' op UM niveau over de tijd vrij stabiel, op faculteitsniveau wat} grilliger

Over het algemeen geldt dat de'employability' indicatoren van UM afgestudeerden relatief stabiel zijn. Uiteraard is de kans op werkloosheid gerelateerd aan de conjunctuur en was er in 2010 een piek in de werkloosheid. De kans op een baan op wo-niveau is sinds 2001 gestaag gestegen. Over de gehele UM ligt het percentage afgestudeerden dat werkzaam is op wo-niveau in 2015 ruim 20\%-punt hoger dan in 2001. De kans op een 
baan in het vakgebied is vrij stabiel over de laatste 15 jaar. Ongeveer 80\% van alle UM afgestudeerden heeft vijf jaar na afstuderen een baan in het vakgebied. De kans op een vaste baan is de afgelopen 15 jaar behoorlijk gedaald. Dit heeft alles te maken met de flexibilisering van de arbeidsmarkt en is dan ook niet specifiek voor UM afgestudeerden. De kans op een baan met een relatief hoog inkomen is de afgelopen 15 jaar gedaald. Hoewel deze kans tussen 2005 en 2009 gestegen is, daalt deze sindsdien. Een dergelijke stijging wordt ook voor andere opleidingsniveaus waargenomen. De tevredenheid met de huidige functie is redelijk stabiel over de afgelopen 15 jaar, hoewel in 2012 en 2015 voor het eerst sinds 2001 minder dan drie kwart van de UM afgestudeerden tevreden is met de baan vijf jaar na afstuderen. Ook met betrekking tot het percentage afgestudeerden dat goede carrièremogelijkheden percipieert is er de laatste jaren, sinds 2011, een lichte afname te zien (van 70 naar 60\%).

Het is bovendien gebleken dat de trend op UM niveau niet hetzelfde verloop heeft als de onderliggende trends per faculteit. Hoewel voor FHML en in iets mindere mate voor SBE over het algemeen geldt dat de 'employability' indicatoren vrij stabiel zijn over de tijd, zijn de meeste 'employability' indicatoren erg veranderlijk over de tijd voor FdR.

\section{Verschillen tussen 'employability' van UM en andere Nederlandse afgestudeerden gering}

De vergelijking tussen UM afgestudeerden en afgestudeerden van andere universiteiten is het beste te maken aan de hand van de HOOP-gebieden.' Over het algemeen zijn de verschillen klein. Toch zijn er een paar interessante verschillen: Het percentage afgestudeerden dat een baan op wo-niveau heeft is hoger onder UM afgestudeerden in de richtingen economie en gedrag \& maatschappij dan onder afgestudeerden van andere Nederlandse universiteiten samengenomen. Met betrekking tot het hebben van een baan in het vakgebied zijn er geen verschillen te vinden tussen UM afgestudeerden en afgestudeerden van andere universiteiten. De kansen op een vaste baan zijn binnen de UM significant lager dan gemiddeld onder afgestudeerden van andere Nederlande universiteiten binnen de HOOP-gebieden gedrag en maatschappij en recht en openbare orde. Dit zou te maken kunnen hebben met het hoge percentage afgestudeerden dat niet afkomstig is uit Nederland en een baan heeft in het buitenland waar andere regelgeving is met betrekking tot vaste banen. De kans op een baan met een relatief hoog inkomen is alleen binnen het HOOP-gebied gezondheidszorg significant anders onder UM afgestudeerden en afgestudeerden van andere Nederlandse universiteiten samengenomen. UM afgestudeerden op het gebied van gezondheidszorg hebben minder vaak een relatief hoog inkomen vergeleken met afgestudeerden van andere Nederlandse universiteiten. De baantevredenheid lijkt niet echt verschillend te zijn onder UM afgestudeerden en afgestudeerden bij andere universiteiten, met uitzondering van het vakgebied gedrag \& maatschappij. Hier scoren UM afgestudeerden relatief gezien minder hoog. Met betrekking tot de carrièremogelijkheden vinden we

$1 \quad$ Het is belangrijk hier op te merken dat er informatie is over een achttal universiteiten. Niet alle universiteiten hebben meegedaan aan de nationale T+5 meting in 2015. 
geen significante verschillen tussen UM afgestudeerden en afgestudeerden van andere universiteiten tesamen.

\section{‘Employability' van UM afgestudeerden verklaard door persoonskenmerken, persoonlijkheid en opleiding}

Uit de analyses komen een aantal determinanten van de 'employability' indicatoren naar voren. Allereerst hebben vrouwen een kleinere kans op een baan op universitair niveau en op een baan een relatief inkomen. Dit laatste geldt 10 jaar na afstuderen nog sterker dan vijf jaar na afstuderen. Afgestudeerden die niet uit Nederland komen zijn over het algemeen beter 'employable'. Ze hebben vaker een baan op wo-niveau en een baan in het vakgebied. Tien jaar na afstuderen hebben ze bovendien vaker een vaste baan. Dit kan alles te maken hebben met selectie-effecten: de betere buitenlandse studenten komen naar de UM of met het feit dat zij vaak een andere arbeidsmarkt bedienen dan de Nederlandse. Niet-Nederlanders blijken wel een significant kleinere kans te hebben om tevreden te zijn met hun baan vijf jaar na afstuderen en om hun carrièremogelijkheden als goed te definiëren. Gepromoveerde academici hebben weliswaar vaker een baan op wo-niveau en binnen hun richting, maar hebben minder vaak een vaste baan en minder vaak een baan met een relatief hoog inkomen. Ze hebben daarentegen wel een grotere kans op goede carrièremogelijkheden. Of afgestudeerden tevreden zijn met hun huidige functie en of zij goede carrièremogelijkheden zien binnen hun huidige functie blijkt vooral ook te maken te hebben met de objectieve maatstaven van 'employability'. Als men binnen het vakgebied werkt en een baan op wo-niveau heeft is men significant tevredener. Carrièremogelijkheden blijken vooral gerelateerd te zijn aan het vereiste opleidingsniveau en het inkomen. Daarnaast blijken carrièremogelijkheden beter voor afgestudeerden met een voltijd- versus een deeltijdbaan. De verschillen per faculteit en per master opleiding zoals gevonden in de beschrijvende statistieken komen over het algemeen in de verklarende analyses terug.

In een laatste set analyses hebben we voor afgestudeerden van een zevental universiteiten nog naar andere mogelijke determinanten gekeken. Een viertal persoonlijkheidskenmerken spelen een rol voor 'employability'. Allereerst hebben extroverte afgestudeerden een kleinere kans op een baan op wo-niveau én zijn ze vaker tevreden met hun huidige baan. Afgestudeerden die meer waarde hechten aan morgen dan aan vandaag hebben juist minder vaak een vaste baan en vaker een lager inkomen. Bovendien vinden we dat afgestudeerden die service gericht zijn, vaker tevreden zijn met hun huidige functie. Als laatste vinden we dat afgestudeerden die relatief bereid zijn om risico's te nemen vaker aangeven goede carrièremogelijkheden te zien binnen hun huidige functie. 



\section{1 \\ INLEIDING}

In 2013 werd door de rector magnificus van Maastricht University (UM) een taskforce 'employability' in het leven geroepen. De taskforce concludeerde dat studenten zich niet voldoende voorbereid voelen op de arbeidsmarkt en dat zij zich niet bewust zijn van hun eigen capaciteiten en de mate waarin deze vereist zijn in de arbeidsmarkt. Bovendien gaven studenten aan dat zij zich onvoldoende geïnformeerd voelen over de mogelijkheden om binnen de UM hun 'employability' te verhogen. Deze bevindingen, tezamen met de resultaten van de UM scanner, die lieten zien dat de 'employability' van UM afgestudeerden op sommige punten verbetering behoeft, hebben gezorgd voor een vergrote aandacht voor 'employability', die zijn weerslag vindt in een "Integrated Strategy for 'Employability"' (Bastiaens en Muijsers, 2016). De komende jaren wordt een aantal onderdelen van deze strategie uitgerold, en worden interventies georganiseerd die als doel hebben de 'employability' van UM afgestudeerden te vergroten.

Het Center for 'Employability' heeft binnen dit kader het ROA benaderd om op basis van een literatuurstudie en de beschikbare data van de UM scanner inzicht te geven in de 'employability' van UM afgestudeerden anno 2015 en de manier waarop 'employability' zich de afgelopen 15 jaar heeft ontwikkeld. Daarnaast is men ook geïnteresseerd in de kenmerken van afgestudeerden en in programma's die positief bijdragen aan de 'employability' van afgestudeerden.

Binnen dit rapport beantwoorden we de volgende vragen:

1. Welke literatuur is er beschikbaar over factoren die de "employability" van afgestudeerden beïnvloeden?

2. Hoe staat het met de 'employability' van UM afgestudeerden anno 2015 (en in hoeverre verschillen faculteiten/opleidingen)?

3. Hoe heeft de 'employability' van UM afgestudeerden zich de afgelopen 15 jaar ontwikkeld?

4. Hoe verhoudt de 'employability' van UM afgestudeerden zich tot die van afgestudeerden van andere universiteiten?

5. Welke kenmerken van afgestudeerden en welke programma's dragen positief bij aan 'employability' van afgestudeerden? 
Voor deelvraag 1 is een uitgebreide literatuurstudie uitgevoerd. In deze literatuurstudie stonden de volgende vragen centraal: wat wordt precies met de term 'employability' bedoeld; uit welke elementen bestaat het; hoe is het meetbaar en kan het vergroot worden? Voor de complete literatuurstudie, zie Mommers et al. (2017).

Deelvragen 2 tot en met 4 tezamen brengen de 'employability' van UM afgestudeerden in kaart. Voor het beantwoorden van deze deelvragen hebben we gebruik gemaakt van de data van de UM scanner waarin afgestudeerden vijf en tien jaar na afstuderen zijn bevraagd. Voor de vergelijking met andere Nederlandse universiteiten hebben we daarnaast gebruik gemaakt van de wo-T+5 meting uit 2015. We hebben op basis van de beschikbare vragenlijstgegevens (en onderbouwd door de literatuurstudie) een zevental indicatoren van 'employability' onderscheiden. Deze zijn gerapporteerd voor het meest recente cohort 2009/2010, zowel op UM niveau als op het niveau van de faculteiten en op HOOP-gebieden vergeleken met andere Nederlandse universiteiten. Daarnaast hebben we de 'employability' indicatoren voor 22 masteropleidingen gerapporteerd. Hiertoe hebben we de data van de vijf meest recente cohorten samengevoegd.

In deelvraag 5 hebben we op basis van de UM scanner een aantal determinanten van de 'employability' indicatoren onderzocht. Om een breder scala aan mogelijke verklarende factoren mee te nemen is ook gebruik gemaakt van de landelijke wo-T+5 meting uit 2015.

Dit rapport is als volgt opgebouwd. Allereerst geven we in Hoofdstuk 2 een beknopt overzicht van de relevante literatuur. Vervolgens staan we in Hoofdstuk 3 stil bij de data, de constructie van de zeven 'employability' indicatoren en de onderzoeksmethode die voor de beschrijvende en verklarende analyses zijn gebruikt. In Hoofdstuk 4 brengen we 'employability' van UM afgestudeerden in kaart en in Hoofdstuk 5 bespreken we determinanten van 'employability'. Ten slotte sluiten we af met een discussie waarin alle bevindingen nog eens op een rij worden gezet en in perspectief worden geplaatst.

Alle beschrijvende statistieken die in dit rapport besproken worden zijn terug te vinden in het bij dit rapport horende tabellenboekje. 


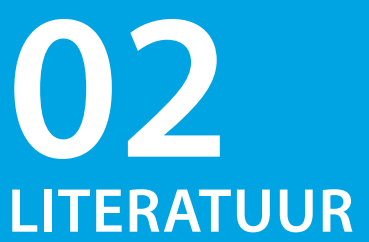

'Employability' is een term die volop gebezigd wordt als het gaat om de perspectieven op de arbeidsmarkt, de ene afgestudeerde is meer'employable' dan de ander. Zelfs als zij over dezelfde opleidingsachtergrond beschikken. Blijkbaar spelen er dus meer aspecten een rol dan enkel de gevolgde opleiding. Vragen die hierbij dan ook onmiddellijk rijzen zijn: wat wordt precies met de term 'employability' bedoeld; uit welke elementen bestaat het; hoe is het meetbaar en kan het vergroot worden? Deze vragen stonden centraal in de uitgevoerde literatuurstudie en zijn aan de hand van de volgende onderzoeksvragen in kaart gebracht:

1. Welke definities van het concept 'employability' kunnen onderscheiden worden?

2. Welke (type) factoren vormen of beïnvloeden de 'employability' van individuen?

3. Welke (meetbare) indicatoren van 'employability' kunnen onderscheiden worden?

4. Hoe kan de 'employability' van individuen vergroot worden, in hoeverre bestaat hier empirische onderbouwing voor?

Bij het beantwoorden van deze vragen hebben we ons specifiek gericht op literatuur over 'employability' in relatie tot het hoger onderwijs. ${ }^{2}$ In dit hoofdstuk wordt een samenvatting van de uitgevoerde literatuurstudie weergegeven. Voor de volledige rapportage, zie Mommers et al. (2017).

\section{Definities}

Ruwweg zijn de definities van 'employability' te ordenen op een schaal van 'zeer individualistisch' tot 'zeer contextueel' georiënteerd. Bij de meer 'individualistische' invullingen gaat het niet zozeer om de feitelijke situatie of iemand met een bepaalde set eigenschappen ook daadwerkelijk werk vindt of heeft, maar of men over een set eigenschappen beschikt die normaliter aantrekkelijk worden beschouwd (o.a. Yorke, 2006). Tegenover deze 'individualistische' benadering, staat de 'contextuele' benadering (o.a. Brown, Hesketh \& Williams 2003). In de meest extreme vorm van deze benadering is iemands 'employability' puur afhankelijk van de arbeidsmarktsituatie (oftewel de conjunctuur). 'Employability' wordt hier zeer expliciet gerelateerd aan het vinden of

2 Een reden hiervoor is dat 'employability' buiten de context van de transitie onderwijs arbeidsmarkt anders gemeten wordt. Zie bijvoorbeeld Raemdonck e.a. (2011) waarin gekeken wordt naar verticale en horizontale baanmobiliteit en De Grip e.a. (2004) waarin gekeken wordt naar de bereidheid en de mogelijkheid om van baan te wisselen. 
hebben van werk. Wanneer er op de arbeidsmarkt meer vraag is dan aanbod, zal in principe iedere werkzoekende 'employable' zijn.

In de praktijk bestaan de meest gangbare definities van 'employability' uit 'mengvormen' van deze invullingen (o.a. Hillage \& Pollard, 1998). In dergelijke definities gaat het vaak om de 'relatieve kansen' van individuen op de (conjunctuurgevoelige) arbeidsmarkt, gegeven hun specifieke set van eigenschappen. Hierin wordt dus zowel verondersteld dat individuele verschillen, alsook de context van invloed is op iemands arbeidsmarktkansen. Afhankelijk van de specifieke definitie kan de focus vooral liggen op het krijgen van werk, het behouden van werk, het tevreden zijn met werk, het mobiel kunnen zijn op de arbeidsmarkt enzovoorts. Kortom: er is géén standaarddefinitie van 'employability'.

\section{Type factoren}

Als we uitgaan van een tussenvorm van een individualistische en contextuele benadering, namelijk dat de 'employability' van studenten/afgestudeerden zowel wordt bepaald door individuele eigenschappen alsook door contextuele kenmerken, kunnen we ruwweg drie typen factoren onderscheiden die een rol spelen bij 'employability'. Individuele factoren, opleidings- en instellingsspecifieke factoren en arbeidsmarktfactoren.

Onder individuele factoren is een schier oneindig aantal relevante persoonskenmerken te onderscheiden. leder theoretisch of empirisch model van 'employability' neemt weer andere aspecten mee. Het breed georiënteerde 'The key to employability' model van Dacre Pool \& Sewell (2007) onderscheidt een vijftal kernelementen: Career development learning (kennis en zelfbewustzijn op het gebied van loopbaanontwikkeling); Experience (werk- en levenservaring); Degree subject knowledge, understanding \& skills (vakspecifieke kennis en vaardigheden); Generic skills (vaak ook 'employability' skills genoemd: generieke vaardigheden zoals creativiteit, flexibiliteit en leergierigheid) en Emotional intelligence (om kunnen gaan met de eigen emoties en met die van anderen). Deze vijf elementen hebben vooral te maken met iemands 'kwaliteiten'. Harvey (2001) stelt echter dat werkgevers niet alleen op kwaliteit selecteren, maar ook op gevoel, vooroordelen en persoonlijke voorkeuren.

Opleidings- en instellingsspecifieke factoren lopen grotendeels via de individuele factoren. Zo heeft de keuze voor een specifieke opleiding gevolgen voor de ontwikkeling van specifieke vakkennis en vakspecifieke vaardigheden. Echter speelt de opleiding (of de instelling) ook een directe rol bij de 'employability' van afgestudeerden. Zo kunnen werkgevers een voorkeur hebben voor studenten vanuit bepaalde instellingen, puur omdat deze een goed 'imago' of sterke 'reputatie' hebben, terwijl dit geen garantie is dat de afgestudeerde zelf ook kwaliteit sterk is.

Tot slot spelen ook arbeidsmarktfactoren een belangrijke rol bij de kansen van afgestudeerden. De kans op werk, het type werk, de beloning voor het werk, al deze aspecten 
zijn mede-afhankelijk van de specifieke arbeidsmarktsituatie (zij het lokaal, regionaal of landelijk) op een bepaald moment. De lokale, regionale en landelijke conjunctuur zijn van grote invloed op de arbeidsmarktperspectieven van afgestudeerden.

\section{Meetbare indicatoren}

Ruwweg zijn er twee typen indicatoren te onderscheiden om 'employability' te meten, objectieve indicatoren en subjectieve indicatoren. De keuze voor het type indicatoren, heeft te maken met de specifieke benadering van 'employability' die men hanteert. Bij de objectieve indicatoren gaat het om 'harde' arbeidsmarktuitkomsten. Deze indicatoren hebben te maken met het al dan niet vinden van werk, en indien men werk heeft met de arbeidsvoorwaarden en de functie-inhoudelijke aspecten (o.a. Firpo, Carvalho \& Pieri 2016; Allen \& Coenen 2011).

Objectieve indicatoren zijn daarmee vooral toepasbaar op de meer 'contextuele' benadering: het geeft aan hoe afgestudeerden het op de arbeidsmarkt doen in verhouding tot elkaar, gegeven de specifieke arbeidsmarktsituatie. Bij 'subjectieve indicatoren' ligt de nadruk vooral op het beoordelen van persoonlijke competenties die nuttig geacht worden op de arbeidsmarkt, vaak ook wel 'employability skills' genoemd. Het gaat dan bijvoorbeeld om 'scores' op karakteristieken zoals leergierigheid of flexibiliteit, maar ook om meer concrete competenties zoals teamwork, communicatie en dergelijke (o.a. Smith, Ferns \& Russell 2014; Fugate \& Kinicki 2008). Daarnaast zijn er nog subjectieve indicatoren die wèl een directe relatie leggen met de baan en dus met de arbeidsmarktsituatie. Voorbeelden zijn de mate waarin de huidige baan aansluit op de competenties van personen en baantevredenheid (o.a. Allen \& Coenen 2011).

\section{'Employability skills' en het onderwijs}

De mate waarin opleidingen en instellingen de nadruk leggen op het bijbrengen van algemene competenties zoals communiceren, samenwerken, ICT-vaardigheden enzovoorts verschilt sterk. Hierdoor zou verondersteld kunnen worden dat de 'employability' van afgestudeerden afkomstig van opleidingen met een sterke aandacht voor die competenties kansrijker zijn op de arbeidsmarkt. Sterke empirische onderbouwing hiervoor wordt in deze literatuurstudie echter niet gevonden (o.a. Cranmer 2006), hoewel de empirische studies vaak alleen kijken naar de kortetermijneffecten (kort na afstuderen). Ook kan geredeneerd worden dat álle opleidingen op zijn minst enige aandacht besteden aan 'employability skills'. Deze competenties kunnen immers wel degelijk waardevol zijn op de arbeidsmarkt, maar omdat alle studenten er in ieder geval iets van meekrijgen, zijn er geen duidelijke significante verschillen waarneembaar.

Waar wel goede aanwijzingen voor zijn, is de bijdrage van praktijkrelevantie in het onderwijs (o.a. Mason, Williams \& Cranmer 2009). Zo hebben studenten met een beroepsstage bijvoorbeeld een grotere kans op werk. Verder zijn er aanwijzingen dat opleidingen waarin het onderwijs samen met het bedrijfsleven wordt ingericht, betere perspectieven bieden voor hun studenten. De hoeveelheid empirische literatuur naar de bijdrage van het onderwijs aan 'employability' en naar de 'waarde' van 'employabi- 
lity skills' is echter beperkt, hetgeen ook onderschreven wordt door de wetenschappers in dit vakgebied zelf. 'Employability' literatuur is vaak theoretisch van aard, waardoor uitspraken over 'effectiviteit' of 'nut' moeilijk te doen zijn. 


\section{3 \\ ONDERZOEKSOPZET}

In dit hoofdstuk wordt de data en de empirische methode rondom de 'employability' van UM afgestudeerden beschreven.

\subsection{Databronnen}

Centraal in de data analyse staan de data van de UM scanner. Op basis van de dataverzameling onder UM alumni in de afgelopen 15 jaar is een trendbestand opgebouwd. In dit trendbestand zijn belangrijke indicatoren voor 'employability' alsook mogelijke verklarende factoren geharmoniseerd zodat deze vergelijkbaar zijn over de tijdreeks. ${ }^{3}$ Het trendbestand bevat daarmee de cohorten 1994/1995 tot en met 2009/2010 voor de $T+5$ meting en 1989/1990 tot en met 2014/2015 voor de T+10 meting.

Daarnaast is in dit rapport gebruik gemaakt van de landelijke T+5 meting uit 2015 waar naast Maastricht University nog zeven andere Nederlandse universiteiten aan deelgenomen hebben. Het betreffen de UvA, de TU Delft, de TU Eindhoven, de RUG, de RU, de EUR, en de UU.

Voor beide databronnen geldt dat we een minimale celvulling van 20 observaties als uitgangspunt hanteren bij het rapporteren van statistieken. Met deze'ondergrens' wordt het risico op onthulling van individuen geminimaliseerd, bovendien zijn uitspraken over kleine(re) aantallen veelal onvoldoende betrouwbaar. Door dit uitgangspunt is het niet mogelijk gebleken om cijfers te rapporteren voor de Faculty of Humanities and Sciences (FHS) van de Universiteit Maastricht. Om op het niveau van individuele masteropleidingen uitspraken te kunnen doen zijn data over de vijf meest recente cohorten samengevoegd.

Naast de $T+5$ en de $T+10$ metingen worden alumni van de UM ook anderhalf jaar na afstuderen bevraagd. De meest recente statistieken op basis van deze meting zijn te vinden in ROA (2016).

3 In de bijlage is een overzicht gegeven met de variabelen die deel uitmaken van het trendbestand. 


\subsection{Maatstaven voor 'employability'}

Op basis van de literatuur zijn een zevental indicatoren voor 'employability' naar voren gekomen waarover we op basis van de UM scanner uitspraken kunnen doen. Het betreffen hier allereerst vijf objectieve maatstaven van 'employability': de kans op werkloosheid, de kans op een baan op universitair niveau, de kans op een baan in de gekozen studierichting, de kans op een voltijdsbaan, de kans op een baan met een relatief hoog inkomen. Daarnaast hebben we twee subjectieve maatstaven van 'employability' geanalyseerd: baantevredenheid en het oordeel over de carrièreperspectieven. We gaan nu achtereenvolgens kort in op de operationalisering van deze indicatoren.

\section{Werkloosheid}

We laten werkloosheidspercentages zien die gebaseerd zijn op de ILO (International Labor Organisation) definitie. Dit houdt in dat personen onderdeel uitmaken van de beroepsbevolking op het moment dat ze minimaal 1 uur per week betaalde arbeid verrichten (werkzame beroepsbevolking) of willen verrichten (werkloze beroepsbevolking). In de context van afgestudeerdenonderzoek is het van belang op te merken dat respondenten die doorleren en op het moment van bevraging student zijn, dus niet tot de beroepsbevolking gerekend worden.

\section{Baan op universitair niveau}

Alumni zijn gevraagd welk opleidingsniveau door hun werkgever minimaal vereist was voor hun huidige functie. Dit is echter niet voor iedereen eenvoudig te beantwoorden. Zo is het vereiste niveau in diverse beroepen niet zonder meer te bepalen, bijvoorbeeld als er bij de werving voor de functie geen specifiek opleidingsniveau werd vereist. Ook is de distinctie tussen bachelor en master voor universitaire functies lang niet altijd evident. Veelal vragen werkgevers een 'wo-denkniveau', waarbij het onderscheid tussen bachelor en master niet gemaakt wordt. Daarnaast is het bachelor-master systeem pas ingevoerd in 2002 waardoor de eerste afgestudeerden uit deze nieuwe regeling die vijf jaar na afstuderen bevraagd zijn pas rond 2007 voorkomen in de dataset. Hierdoor valt een groot gedeelte onder het oude systeem en is voor deze groep geen distinctie mogelijk.

In de meest recente bevragingen onderscheiden we de volgende opleidingsniveaus: wo gepromoveerd, wo master, wo bachelor, hbo master, hbo bachelor, hbo associate degree, havo/vwo, mbo, vmbo of lager. Vóór de invoering van het bachelor/master systeem was het aantal antwoordcategorieën vanzelfsprekend kleiner. Ten bate van het trendbestand zijn de verschillende wo 'niveaus' (bachelor, master en gepromoveerd) samengevoegd tot de hoofdcategorie'wo'. Daarmee kan een baan op universitair niveau onderscheiden worden van de overige niveaus. ${ }^{4}$

$4 \quad$ Ook in de jaarlijkse factheets waarin de arbeidsmarktsituatie van UM afgestudeerden wordt gerapporteerd is voor deze definitie gekozen. Zie bijvoorbeeld ROA (2016). 


\section{Baan binnen vakgebied}

Of een baan aansluit bij de gekozen studierichting is voor de ene studie makkelijker te beoordelen dan voor andere. Aan afgestudeerden is gevraagd welke opleidingsrichting door hun huidige werkgever vereist werd. De vier mogelijke antwoordcategorieën waren uitsluitend mijn eigen richting, mijn eigen of verwante richting, een geheel andere richting of geen specifieke richting. We definiëren een baan binnen het vakgebied als een baan waarbij iemands eigen richting of verwante opleidingsrichting vereist was.

\section{Vaste baan}

Wat betreft het type aanstelling kan onderscheid gemaakt worden tussen een vaste baan, een tijdelijke baan met uitzicht op vaste baan en een tijdelijke baan zonder uitzicht op een vaste baan. Een van de indicatoren voor 'employability' is het hebben van een vaste baan.

\section{Baan met een relatief hoog inkomen}

In de vragenlijst wordt gevraagd naar iemands bruto maandinkomen. De beloning van de afgestudeerden kan alleen geïnterpreteerd worden in de bredere context van de economische situatie en landelijke uurlonen. Daarom is een inflatiecorrectie toegepast en analyseren we het inkomen ten opzichte van het mediaan inkomen van de gehele UM voor het meest recente cohort 2009/2010. Doordat we het mediaan inkomen pakken maken we een correctie voor de al dan niet extreem hoge of lage antwoorden. De keuze voor het meest recente cohort zorgt ervoor dat we de vergelijking trekken tot het meest recente referentiekader. Kortom, een afgestudeerde met een inkomen boven de mediaan van het cohort 2009/2010 wordt gecategoriseerd als iemand met een relatief hoog inkomen.

\section{Baantevredenheid}

Met uitzondering van het cohort 2008/2009 zijn alle cohorten bevraagd naar de tevredenheid over hun huidige baan. Alumni konden op een vijfpuntschaal antwoorden van (1) zeer ontevreden tot (5) zeer tevreden. Alumni die hun tevredenheid met een 4 of een 5 beoordeelden, zijn gedefinieerd als tevreden met hun baan.

\section{Goede carrièreperspectieven}

Via de alumnivragenlijsten is inzicht verkregen in het oordeel van afgestudeerden over de carrièreperspectieven in hun huidige baan. De alumni konden op een vijfpunt schaal aangeven of hun functie goede carrièreperspectieven biedt. Hierbij indiceert een (1) nauwelijks carrièreperspectieven en een (5) heel veel carrièreperspectieven. Indien men de carrièreperspectieven met een 4 of 5 heeft beoordeeld, interpreteren we dit als 'goede carrièreperspectieven'.

De indicatoren baan op universitair niveau, baan in het vakgebied, vaste baan en relatief hoog inkomen zijn alleen voor afgestudeerden in loondienst berekend. 


\subsection{Onderscheiden faculteiten}

Sinds afstudeercohort 1989/1990 hebben er een aantal wijzigingen in de faculteitsstructuur van de UM plaatsgevonden. In dit rapport hebben we de actuele faculteitstructuur aangehouden. We onderscheiden daardoor de volgende faculteiten: School of Business and Economics (SBE), Faculty of Health, Medicine and Life Sciences (FHML), Faculty of Arts and Social Sciences (FASOS), Faculty of Psychology and Neuroscience (FPN), Faculteit der Rechten (FdR). Voor Faculty of Humanities and Sciences (FHS) kunnen we geen statistieken rapporteren omdat we voor deze faculteit niet voldoen aan de ondergrens van 20 observaties. ${ }^{5}$ Gezien de geschiedenis van FHML en de omvang van deze faculteit onderscheiden we binnen FHML de voormalige faculteiten Faculteit der Geneerskunde (FdG) en Faculteit der Gezondheidswetenschappen (FdGW).

\subsection{Typen analyses}

In Hoofdstuk 4 brengen we de 'employability' indicatoren voor UM afgestudeerden in kaart. Allereerst behandelen we de 'employability' indicatoren voor het meest recente cohort op. Vervolgens wordt de vijftienjaarstrend van deze indicatoren weergeven. Op deze manier kan bekeken worden of het meest recente cohort een uitschieter is of dat de indicator redelijk stabiel is over de tijd. Daarnaast kan door het analyseren van de trends inzicht verkregen worden in de conjunctuurgevoeligheid van de 'employability' indicatoren. ${ }^{6}$ Vervolgens wordt op het niveau van de verschillende HOOP-gebieden ${ }^{7}$ gekeken hoe de afgestudeerden van de UM het doen in vergelijking met afgestudeerden van andere Nederlandse universiteiten. Hoofdstuk 4 sluit af met een overzicht van de indicatoren van 'employability' naar masteropleiding. Hiertoe voegen we de vijf meest recente cohorten samen.

In Hoofdstuk 5 rapporteren we regressieanalyses waarin we pogen de employability van individuele afgestudeerden te verklaren. Deze analyses doen we allereerst op de vijf meest recente UM cohorten gezamenlijk. Vervolgens doen we nog analyses op het landelijke afgestudeerden $\mathrm{T}+5$ bestand omdat hier meer (mogelijke) determinanten in de vragenlijst opgenomen zijn. Ook is het op basis van deze laatste analyses mogelijk om te kijken of de 'employability' van afgestudeerden, gecontroleerd voor persoons- en opleidingsfactoren, significant verschillen tussen de Nederlandse universiteiten.

$5 \quad$ Een uitzondering hierop zijn de beschrijvende statistieken en analyses waarbij we data van de vijf meest recente cohorten samenpakken.

6 We vermelden waar mogelijk en interessant ook trends per faculteit.

7 Indeling die door o.a. VSNU en het ministerie OCW wordt gebruikt om (universitaire) onderwijssectoren te beschrijven. 


\section{4 \\ EMPLOYABILITY VAN UM \\ AFGESTUDEERDEN IN KAART GEBRACHT}

\subsection{Werkloosheid}

Het vinden van werk is de meest elementaire en meest gebruikte indicator van 'employability' (o.a. Smith, McKnight \& Naylor, 2000; Lim, 2010; Firpo, Carvalho \& Pieri, 2016). In Figuur 4.1 is het werkloosheidspercentage onder UM-afgestudeerden van het cohort 2009/2010 te zien vijf jaar na afstuderen. Onder deze groep UM-afgestudeerden ligt het werkloosheidspercentage op 3,4\%. Afgestudeerden van SBE, FPN en FdR doen het enigszins beter met lagere werkloosheidspercentages tussen de 1,5 en 2,5\%. Het werkloosheidspercentage ligt voor afgestudeerden van FASoS hoger; $6,7 \%$ van de afgestudeerden behoort vijf jaar na afstuderen tot de werkloze beroepsbevolking. Ook het werkloosheidspercentage onder FHML afgestudeerden ligt hoger dan het UM gemiddelde (5,2\%). Binnen FHML zien we dat het werkloosheidspercentage iets hoger is onder afgestudeerden van FdGW (5,3\%) dan FdG (4,9\%).

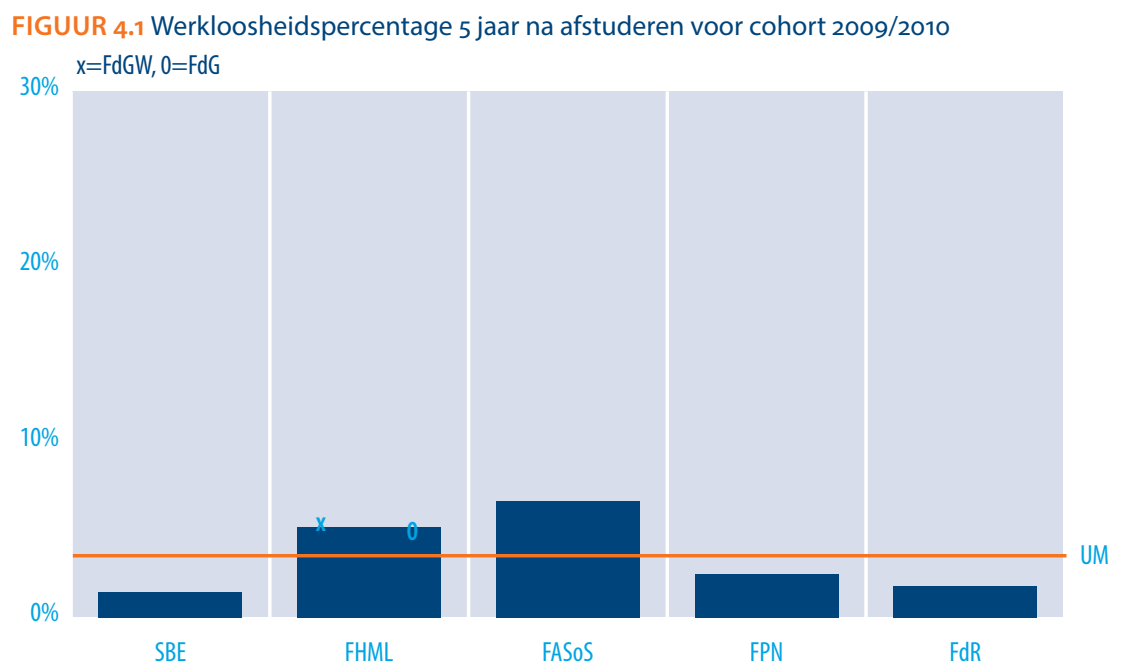

Bron: UM scanner 2015 
Het relatief lage werkloosheidspercentage van de UM afgestudeerden van het 2009/2010 cohort is niet uitzonderlijk. Figuur 4.2 laat de werkloosheidspercentages vijf jaar na afstuderen zien voor de 15 meest recente cohorten. De figuur toont dat er de afgelopen 15 jaar zelfs een lichte stijging is in het werkloosheidspercentage onder UM afgestudeerden. Waar het percentage onder de $2 \%$ lag in 2001 is deze opgelopen tot 3,5\% in 2015. In de nasleep van de crisis in 2008 is er een stijging te zien naar de hoogste piek in 2010 waar het werkloosheidpercentage uitkwam op 4,4\%. Deze piek geeft het hoogste werkloosheidspercentage over de gehele onderzochte periode weer.

De trends per faculteit zien er grillig uit, ${ }^{8}$ waarschijnlijk een gevolg van het relatief lage aantal observaties. Zo schommelt het werkloosheidspercentage onder FPN afgestudeerden tussen de $\% \%$ en de $7 \%$. In 2010 is zelfs één op de tien FPN afgestudeerden vijf jaar na afstuderen werkloos. Ook binnen FASoS zien we, als gevolg van het lage aantal observaties, uiteenlopende werkloosheidscijfers. Terwijl er in 2006 tot en met 2009 geen werklozen waren onder de FASoS respondenten, lag het werkloosheidspercentage in de jaren daarna tussen de $3 \%$ en $8 \%$.

Maar ook voor SBE, een grotere faculteit, observeren we pieken en dalen die elkaar snel opvolgen. Terwijl in 2003, 2005 en 2010 het werkloosheidspercentage onder SBE afgestudeerden boven de 4\% lag, lag in 2001, 2002, 2004, 2006, 2007 en tussen 20112015 het werkloosheidspercentage onder de $2 \%$. Onder afgestudeerden van FdR is er in diverse jaren geen sprake van werkloosheid onder de respondenten, in andere jaren ligt de werkloosheid boven de 2\% (2001, 2009, 2010, 2012, 2013, 2014). In 2012 was het werkloosheidspercentage onder deze groep afgestudeerden $6,8 \%$. Het werkloosheidspercentage onder afgestudeerden van FHML is het meest stabiel rond de $2 \%$.

FIGUUR 4.2 Trend in werkloosheid

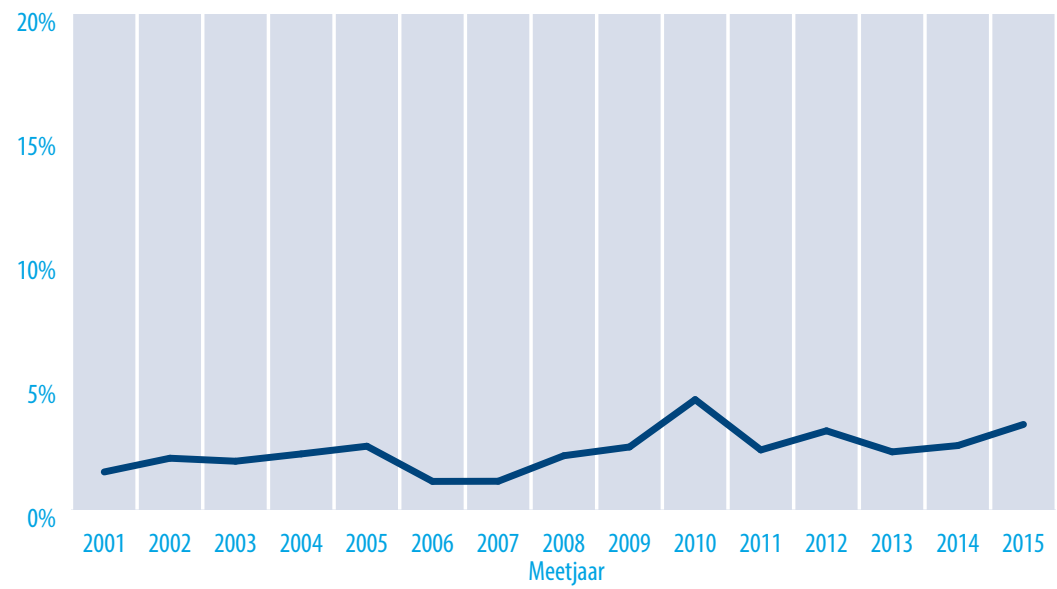

Bron: UM scanner 2001-2015

8 De trends per faculteit zijn te vinden in het tabellenboekje. 
In Figuur 4.3 laten we zien in hoeverre het werkloosheidspercentage onder UM-afgestudeerden overeen komt met het landelijk gemiddelde. Hierin onderscheiden we de verschillende HOOP-gebieden'. Voor de UM als geheel blijkt het werkloosheidspercentage erg vergelijkbaar met de overige Nederlandse universiteiten. Opgesplitst naar HOOP-gebied, vinden we geen significante verschillen.

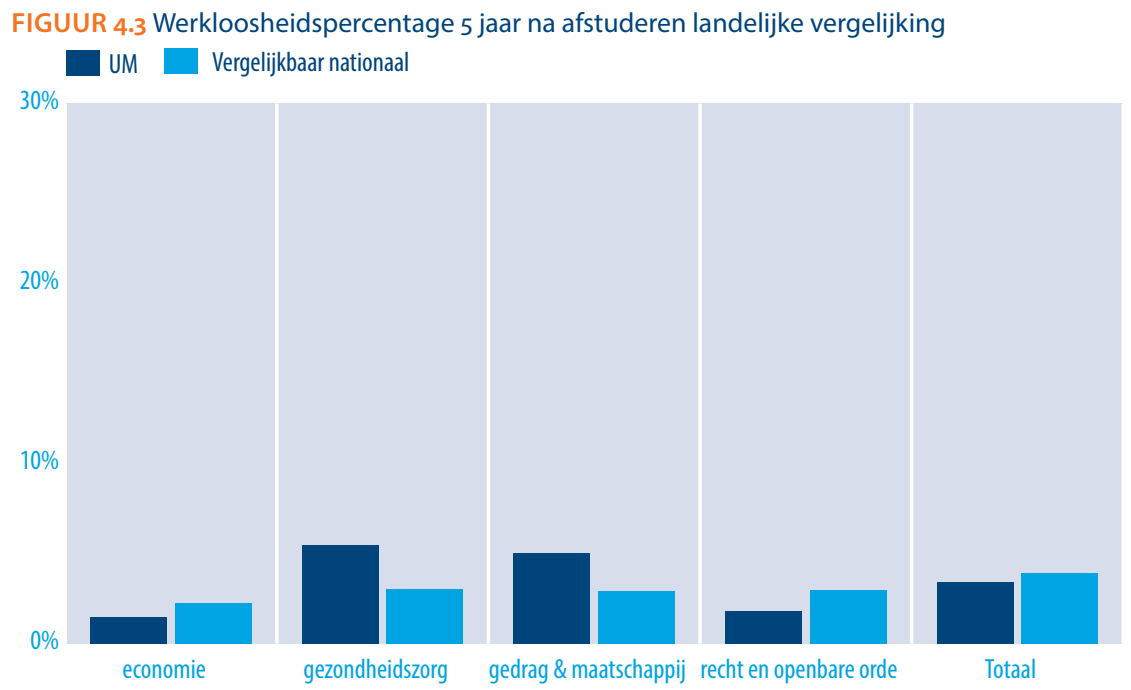

Bron: UM scanner 2015, wo T+5 2015

\subsection{Baan op universitair niveau}

Een van de functie-inhoudelijke indicatoren van 'employability' betreft het hebben van een baan op het eigen opleidingsniveau (o.a. Allen et al., 2009; Allen \& Coenen, 2011). Het percentage UM-afgestudeerden uit het cohort 2009/2010 met een baan op universitair niveau wordt in Figuur 4.4 weergegeven. Voor de UM als geheel geldt dat 83,4\% van alle afgestudeerden vijf jaar na afronden van de studie een baan op universitair niveau heeft. Waar het percentage afgestudeerden van SBE, FHML en FdR dat 5 jaar na afstuderen een universitair functie heeft gevonden rond de $84 \%$ ligt, is dit percentage voor afgestudeerden van FPN aanmerkelijk hoger (93\%). Naast een relatief lage werkloosheid geldt voor FPN afgestudeerden dus ook een relatief grote kans op een baan op universitair niveau. Voor afgestudeerden van FASoS is het percentage werkenden op universitair niveau relatief lager, $78 \%$ heeft vijf jaar na afstuderen een universitaire functie gevonden. Voor deze groep afgestudeerden geldt dus zowel een hogere kans op werkloosheid, als een lagere kans op een baan op wo-niveau. Binnen de medische faculteit zien we dat álle FdG afgestudeerden een baan op universitair niveau hebben, terwijl slechts $73 \%$ van de afgestudeerden van FdGW vijf jaar na afstuderen een baan op wo-niveau heeft. Mogelijke reden voor de positieve cijfers voor de FdG kan de specifieke

9 Voor zover deze onderwijssectoren aanwezig zijn op de UM. 
(beroeps)kennis zijn die geleerd wordt waardoor een baan onder universitair niveau minder voor de hand ligt.

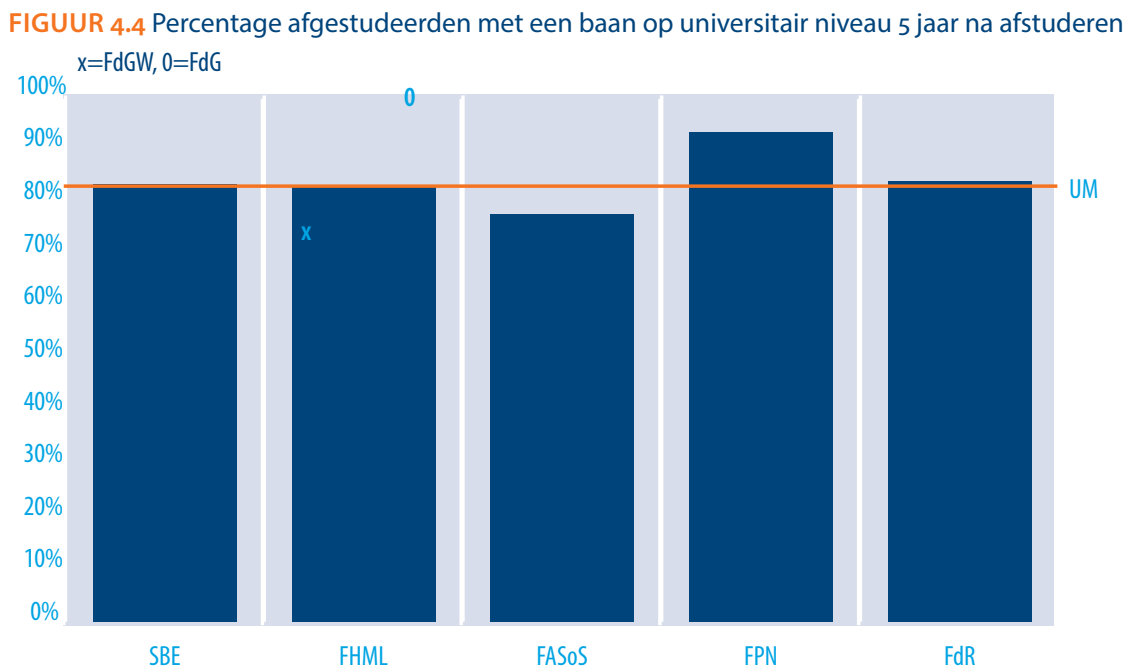

Bron: UM scanner 2015

De ontwikkeling van het percentage UM-afgestudeerden werkend op universitair niveau tussen 2000 en 2015 wordt in Figuur 4.5 weergegeven. Hieruit blijkt dat er een stijging plaatsgevonden heeft in het percentage UM-afgestudeerden dat op universitair niveau werkt. Waar dit percentage nog 67\% bedroeg in 2003 was in 2013 maar liefst 89\% werkzaam in een functie op universitair niveau. Hierbij moet wel gezegd worden dat de stijging vooral plaatsvond in de beginjaren. De laatste tien jaar is er niet veel variatie meer zichtbaar. In de laatste twee jaar, getekend door de crisis op het moment van afstuderen, is er een kleine daling waarneembaar in het percentage UM-afgestudeerden werkend op universitair niveau maar het percentage ligt nog steeds boven de $80 \%$.

De trends per faculteit zijn voor het percentage werkzaam op wo-niveau minder grillig dan voor de werkloosheid. Met name FASoS (rond 85\%), FHML (rond 75\%) en FdR (85\%) laten redelijk stabiele percentages zien. Bij FHML is er één uitschieter naar boven; in 2013 werkte 90\% van de afgestudeerden vijf jaar na afstuderen in een baan op universitair niveau. Bij FASoS is er juist een uitschieter naar beneden; in 2015 werkte $78 \%$ op wo-niveau. Bij SBE zijn er twee periodes van groei waarneembaar: tussen 2001 (61\%) en 2006 (86\%) en tussen 2010 (80\%) en 2013 (94\%).

Figuur 4.6 geeft een positief beeld van UM-afgestudeerden vergeleken met afgestudeerden van andere universiteiten als het gaat over het werkzaam zijn op universitair niveau. Over de gehele UM ligt het percentage afgestudeerden dat op universitair niveau werkt ruim 10\%-punt hoger. Binnen de HOOP-gebieden economie en gedrag en 
maatschappij werkt een significant hoger percentage UM-afgestudeerden op universitair niveau, bij gedrag een maatschappij scheelt dit zelfs bijna 20\%-punt. Hoewel UM afgestudeerden van deze opleidingsrichting dus relatief meer kans hebben op werkloosheid, geldt dat áls zij een baan vinden, ze wel meer kans hebben op een baan op wo-niveau dan gemiddeld genomen. Voor de overige HOOP-gebieden vinden we geen significant verschil in de kans op een baan op wo-niveau tussen de UM en de andere Nederlandse universiteiten.

\section{FIGUUR 4.5 Trend in percentage afgestudeerden werkzaam op universitair niveau}

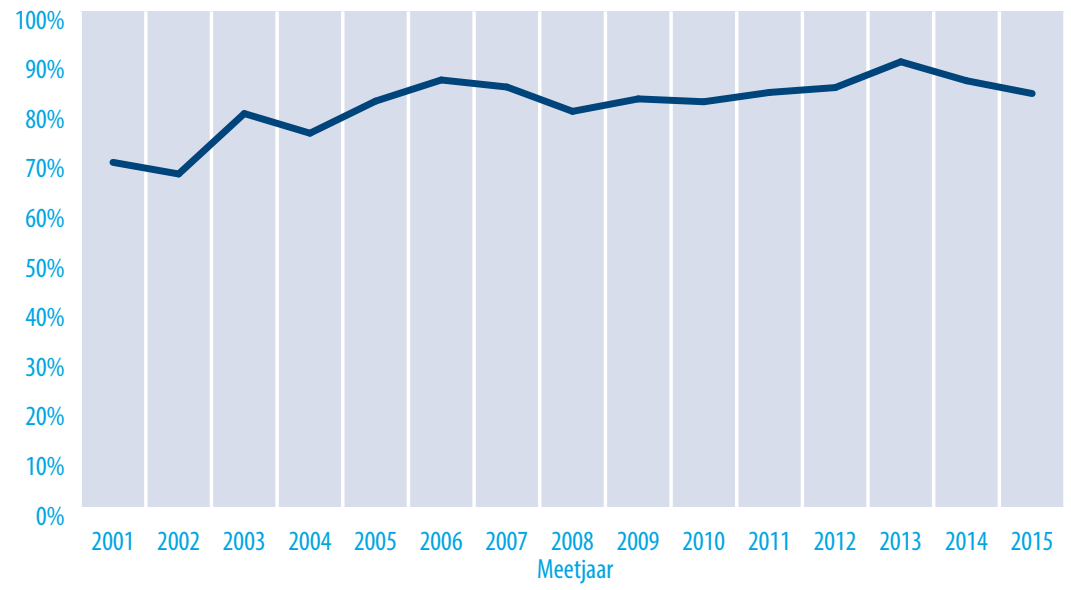

Bron: UM scanner 2001-2015

FIGUUR 4.6 Percentage afgestudeerden met een baan op universitair niveau 5 jaar na afstuderen landelijke vergelijking

UM Vergelijkbaar nationaal

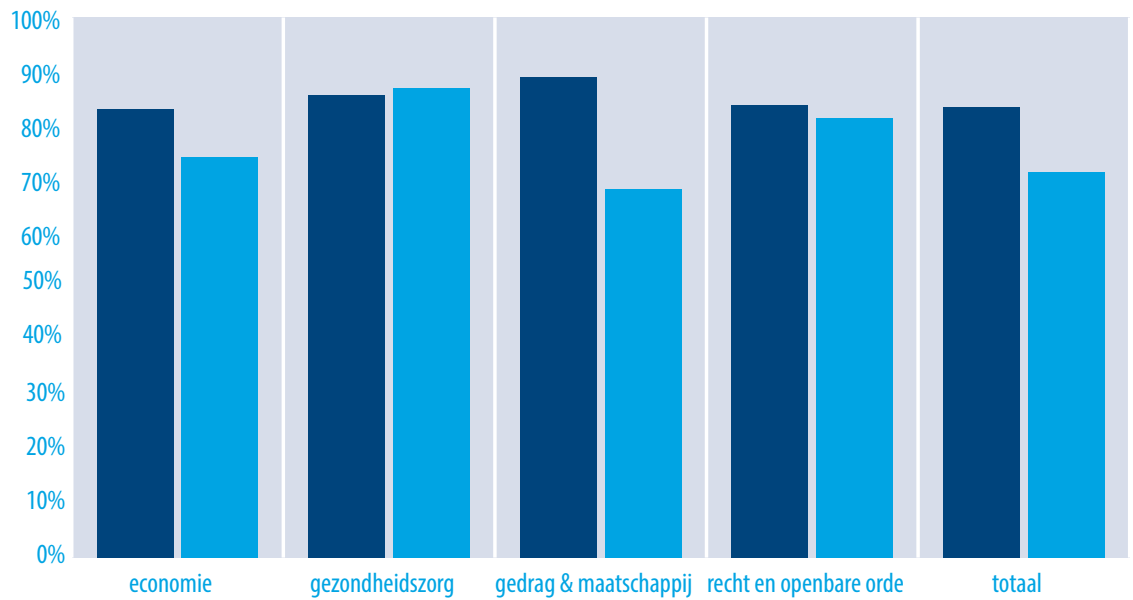

Bron: UM scanner 2015, wo T+5 2015 


\subsection{Baan binnen vakgebied}

Naast het percentage afgestudeerden op universitair niveau kijken we ook naar het aantal afgestudeerden werkzaam in de gekozen of een verwante opleidingsrichting (cf. o.a. Allen et al., 2009; Allen \& Coenen, 2011).

In Figuur 4.7 laten we het percentage van de UM afgestudeerden uit cohort 2009/2010 zien dat vijf jaar na afstuderen een baan binnen het vakgebied gevonden heeft. Van alle UM-afgestudeerden heeft ongeveer $80 \%$ vijf jaar na afstuderen een baan binnen het vakgebied gevonden. Met $96 \%$ doen vooral de afgestudeerden van FPN het goed, maar ook onder afgestudeerden van FHML en FdR heeft een hoog percentage van haar afgestudeerden werk in de gekozen opleidingsrichting gevonden. Binnen FHML zijn het wederom de afgestudeerden van geneeskunde die het gemiddelde omhoog trekken. Alle geneeskunde afgestudeerden werken namelijk binnen hun vakgebied. Onder FdGW afgestudeerden is dit $85 \%$. Afgestudeerden van FASoS hebben meer moeite om banen binnen hun vakgebied te vinden: $58 \%$ vindt een baan in het eigen vakgebied.

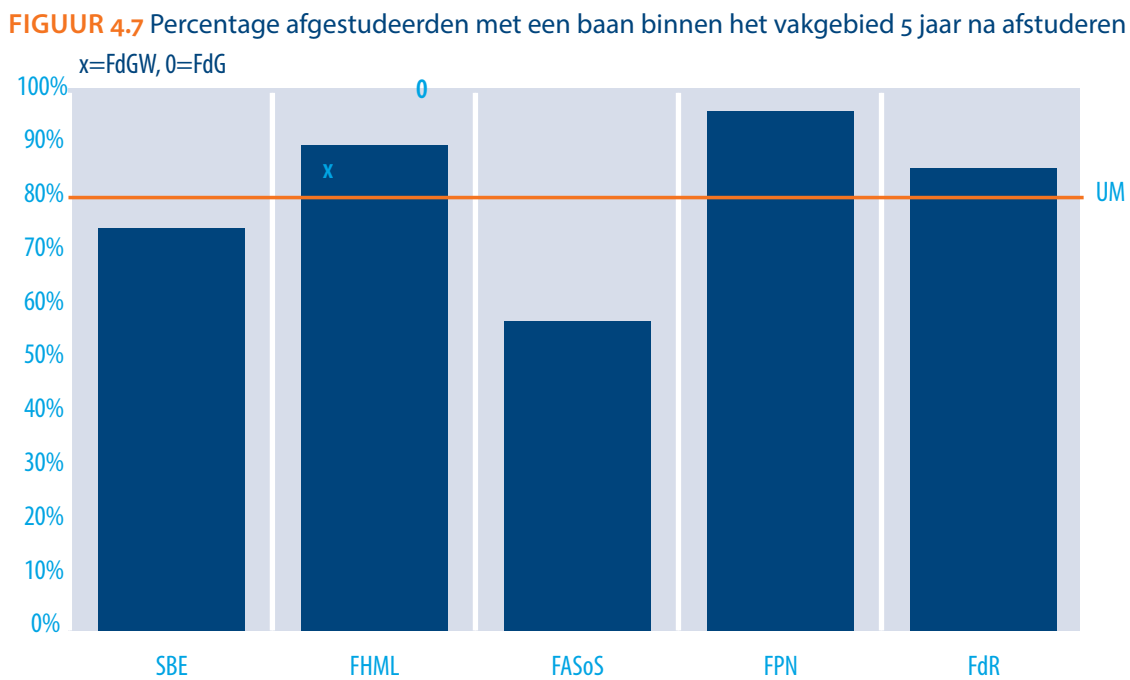

Bron: UM scanner 2015

In Figuur 4.8 is het percentage UM afgestudeerden dat vijf jaar na afstuderen een baan binnen hun vakgebied heeft voor de periode 2000-2015 weergegeven. Het percentage blijkt vrij stabiel over de tijd. De meeste variatie is in de beginjaren te zien, met onder andere een licht dalende lijn vóór 2004, de laatste jaren ligt het percentage dat werkzaam is in het igen vakgebied rond de $80 \%$. 
Onder FHML en FPN afgestudeerden is er betrekkelijk weinig variatie te zien over de tijd. De enige uitzondering is het laatste meetjaar waarbij FPN afgestudeerden aanzienlijk vaker een baan binnen het vakgebied vonden dan in de eerdere jaren. Bij SBE en FdR is meer variatie in het percentage afgestudeerden dat een baan heeft binnen het vakgebied. Grofweg ligt dit percentage onder SBE afgestudeerden tussen de $75 \%$ en $80 \%$, met enige fluctuaties naar boven ( $88 \%$ in 2011) en naar beneden $(63 \%$ in 2004$)$ is. Onder afgestudeerden van FdR schommelde het percentage werkenden binnen het vakgebied sterk tot 2006. Vanaf 2007 tot en met 2015 is er een opwaartse trend waarneembaar. In die periode is het percentage gestegen van $74 \%$ naar $86 \%$. In 2012 was hierop een uitzondering, toen was het percentage werkenden dat een baan binnen het vakgebied had met $62 \%$ het laagste sinds 2001 .

FIGUUR 4.8 Trend in percentage afgestudeerden werkend binnen het vakgebied

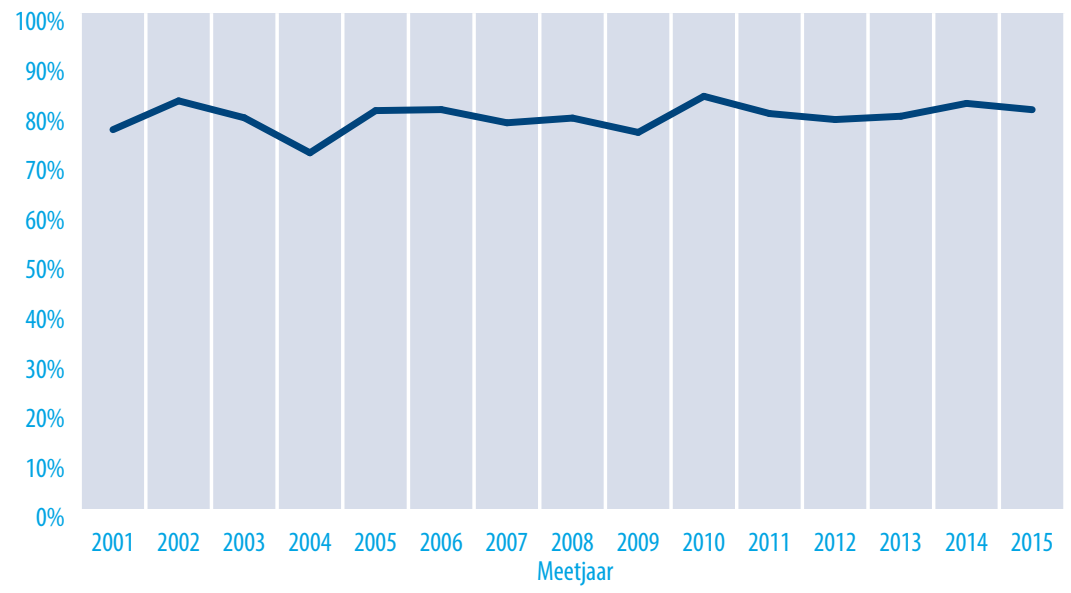

Bron: UM scanner 2000-2015

In Figuur 4.9 is de landelijke vergelijking te zien met betrekking tot een baan binnen het vakgebied. Hoewel het verschil kleiner is dan bij het werken op universitair niveau blijkt uit de nationale vergelijking in Figuur 4.9 dan de UM-afgestudeerden het in nationale context goed doen als het gaat om werken binnen het vakgebied. Het verschil tussen de UM en de andere Nederlandse universiteit is op 10\% significant. Er blijken op HOOP-gebied geen significante verschillen te zijn tussen UM afgestudeerden en afgestudeerden uit andere Nederlandse universiteiten. 
FIGUUR 4.9 Percentage afgestudeerden met een baan binnen het vakgebied 5 jaar na afstuderen, landelijke vergelijking

UM Vergelijkbaar nationaal

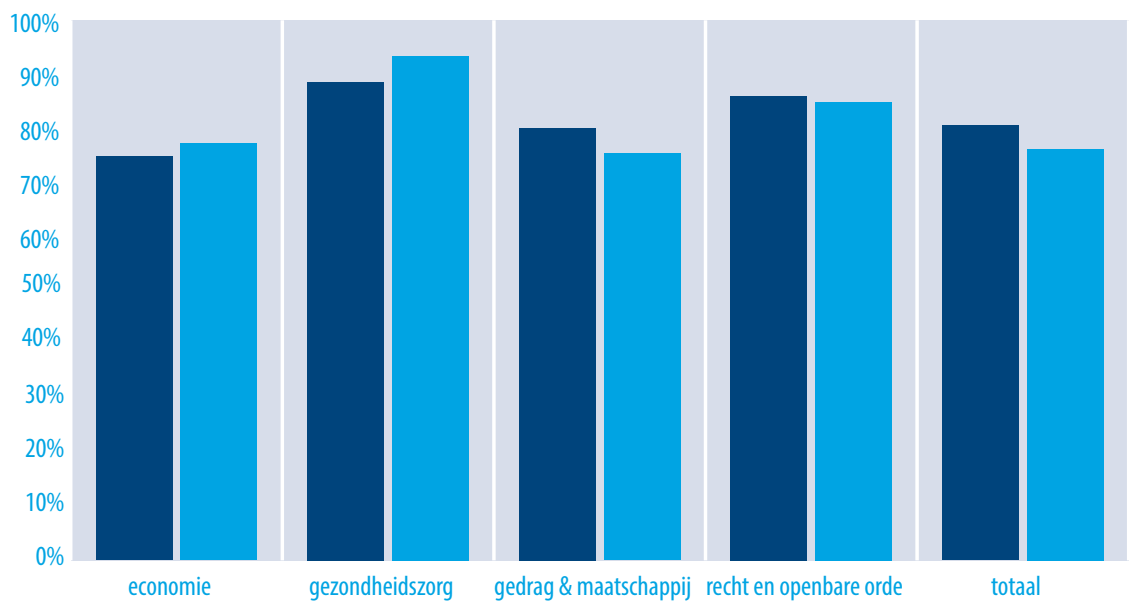

Bron: UM scanner 2015, wo T+5 2015

\subsection{Vaste baan}

De indicator 'het hebben van een vaste baan' gaat een stap verder dan enkel het wel of niet vinden van werk (Harvey, 2001). Figuur 4.10 laat zien dat van alle UM afgestudeerden uit het cohort $2009 / 2010$ ruim $65 \%$ vijf jaar na afstuderen een vaste baan heeft. De figuur laat ook zien dat er behoorlijke verschillen zijn tussen afgestudeerden van de verschillende faculteiten. Afgestudeerden van SBE steken duidelijk boven alle andere faculteiten uit en trekken het UM-gemiddelde omhoog. Ongeveer $90 \%$ van de werkende SBE-afgestudeerden heeft vijf jaar na afstuderen een vaste baan gevonden. Dit percentage ligt met ongeveer $63 \%$ aanmerkelijk lager voor afgestudeerden van FASoS en FdR. lets minder dan de helft van alle FPN afgestudeerden heeft vijf jaar na afstuderen een vaste baan. Voor de FHML afgestudeerden zien we een vaste-baan-percentage van slechts $43 \%$. Echter, er blijken grote verschillen in de kans op een vaste baan tussen FdG (22\%) afgestudeerden en de afgestudeerden van FdGW (54\%). Het relatief lage percentage mensen met een vaste baan onder de geneeskunde afgestudeerden is het gevolg van het feit dat men na het afronden van de master basisarts is. Een groot deel van de afgestudeerden vindt daarna een baan als arts in opleiding tot specialist (AIOS). Afhankelijk van de specialisatie duurt dit 3 tot 6 jaar. Een ander deel gaat juist de wetenschap in, en ook dat gaat vaak gepaard met een baan met een tijdelijk contract. Het is daarom niet verwonderlijk dat men vijf jaar na het afronden van de master basisarts veelal nog geen vaste baan heeft. 
FIGUUR 4.10 Percentage afgestudeerden met een vaste baan 5 jaar na afstuderen

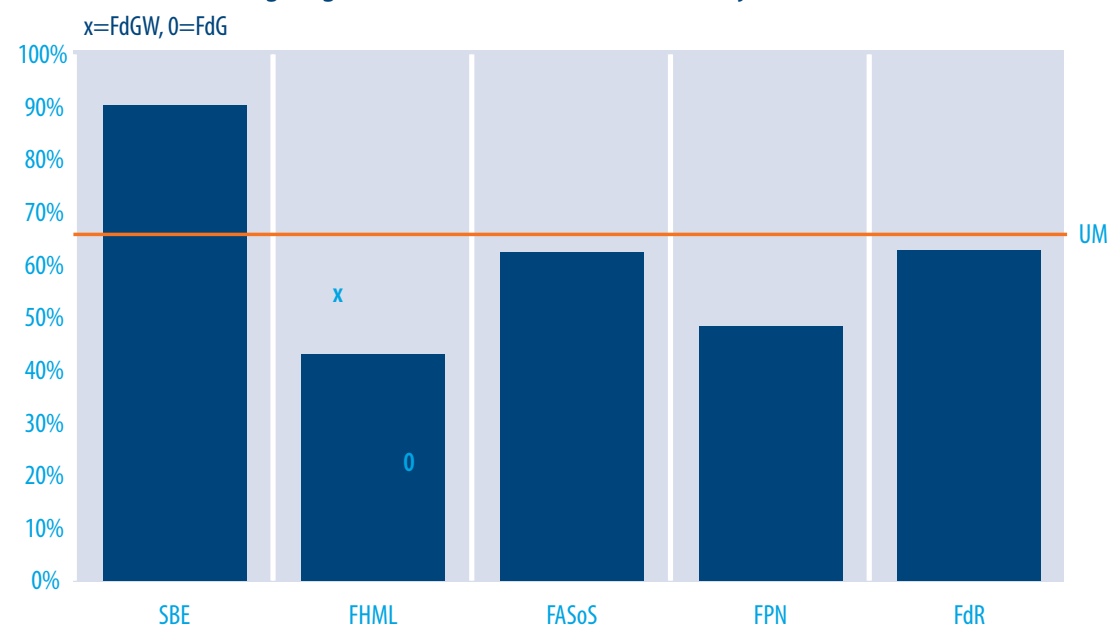

Bron: UM scanner 2015

In Figuur 4.11 is de ontwikkeling tussen 2000 en 2015 van het percentage afgestudeerden met een vaste baan weergegeven. De figuur laat een duidelijke daling zien. Terwijl in 2001 nog $85 \%$ van de afgestudeerden vijf jaar na afstuderen een vaste aanstelling had, is dit percentage anno 2015 nog maar 66\%. Tussen 2004 en 2012 was het percentage met een vaste baan vrij stabiel rond de $80 \%$, maar sindsdien neemt het percentage vaste aanstellingen onder UM-afgestudeerden trapsgewijs af. Deze trend is niet specifiek voor de UM of wo-afgestudeerden in het algemeen. Voor mbo-bol afgestudeerden is het aandeel werkenden met een flexibele aanstelling anderhalf jaar na afstuderen in de afgelopen 10 jaar met 27\%-punt toegenomen (van 44\% in 2005 naar $71 \%$ in 2015). Voor mbo-bbl afgestudeerden geldt een toename van 10\%-punt tot 29\% in 2015 en voor hbo-afgestudeerden geldt een toename van 18\%-punt tot 71\% in 2015 (ROA 2016b). Ook Gaalen e.a. (2013) laten zien dat er sprake is van een landelijke groei van de flexibele schil.

Het percentage afgestudeerden met een vaste baan vijf jaar na afstuderen is binnen de faculteiten SBE (90-95\%) en FPN (65\%) relatief stabiel. Binnen FdR is er tussen 2001 en 2011 een forse afname van $94 \%$ naar $80 \%$. Daarna is er sprake van grote fluctuaties met een flinke afname naar $63 \%$ in 2015 . Ook binnen FHML is er sprake van een afname, met name sinds 2012.

Figuur 4.12 laat zien dat wo-afgestudeerden in algemene zin vaak te maken hebben met tijdelijke contracten. Landelijk gezien is het percentage afgestudeerde wo-ers met een vaste baan vijf jaar na afstuderen $69 \%$. Afgestudeerden van de UM hebben een significante kleinere kans op een vaste baan dan afgestudeerden van andere Nederlandse universiteiten. Economen hebben de grootste kans op een vaste baan terwijl afgestudeerden in de gezondheidszorg de kleinste kans hebben. Het hierboven besproken vervolgtraject van geneeskunde studenten is hier een duidelijke reden voor. De kansen 
op een vaste baan zijn binnen de UM significant lager dan gemiddeld onder afgestudeerden van andere Nederlande universiteiten binnen de HOOP-gebieden gedrag en maatschappij en recht en openbare orde.

FIGUUR 4.11 Trend in percentage afgestudeerden met een vaste baan

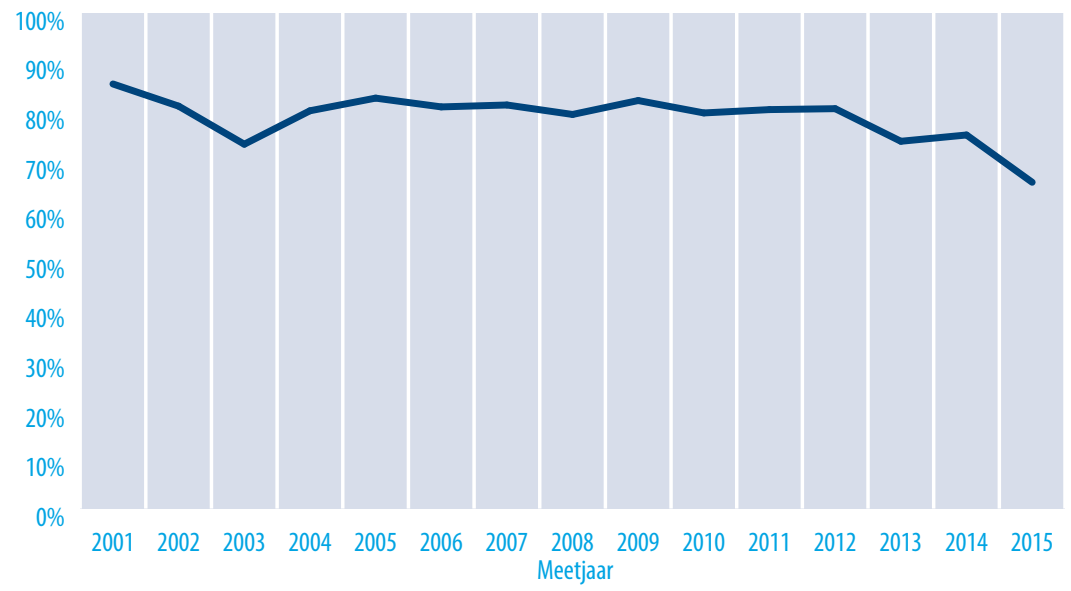

Bron: UM scanner 2001-2015

FIGUUR 4.12 Percentage afgestudeerden met een vaste baan 5 jaar na afstuderen, landelijke vergelijking

UM Vergelijkbaar nationaal

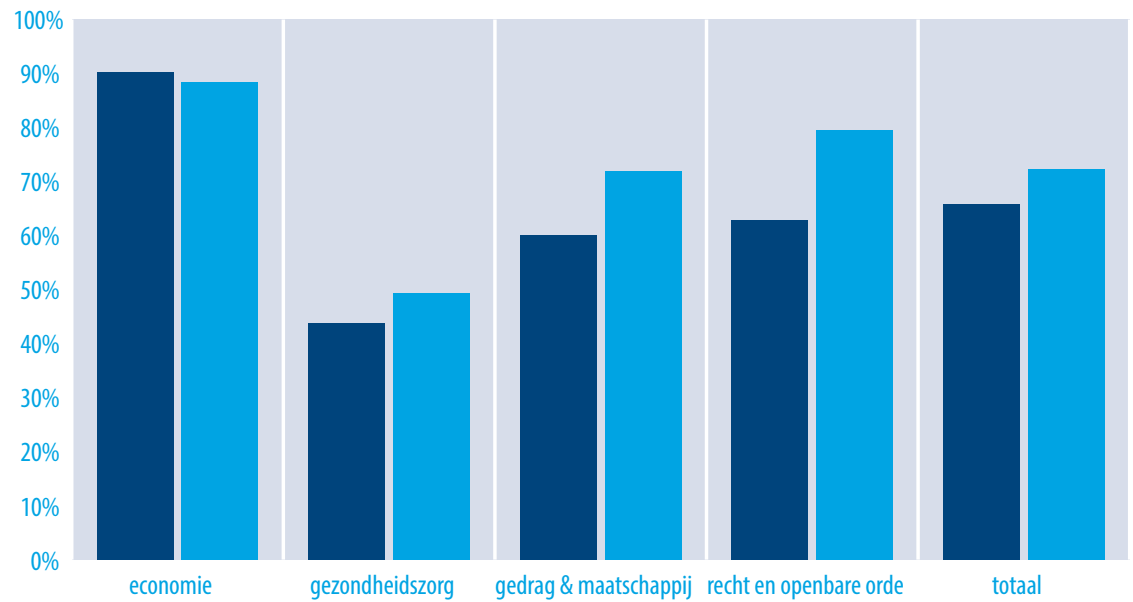

Bron: UM scanner 2015, wo T+5 2015 


\subsection{Relatief hoog inkomen}

Een andere belangrijke indicator van het succes van een opleiding en de start op de arbeidsmarkt is het salaris van de afgestudeerden (ROA, 2016b). In Figuur 4.13 is het percentage afgestudeerden met een relatief hoog inkomen vijf jaar na afstuderen weergegeven. Per definitie ligt het UM brede gemiddelde op 50\%. De figuur laat duidelijke verschillen tussen de faculteiten zien. Afgestudeerden van SBE steken net zoals bij het aandeel afgestudeerden met een vaste aanstelling ook hier boven de andere faculteiten uit. Onder de SBE-afgestudeerden heeft 75\% een baan met een relatief hoog inkomen vijf jaar na afstuderen, gevolgd door afgestudeerden van FdR met $42 \%$ en daar weer op volgend de afgestudeerden van FPN en FHML. Het laagste percentage afgestudeerden met een relatief hoog inkomen is gevonden voor FASoS afgestudeerden. Slechts $27 \%$ van de afgestudeerden heeft vijf jaar na afstuderen een baan met een relatief hoog inkomen. Deze bevinding is in lijn met de relatief lage kans op een baan op wo-niveau voor deze groep.

FIGUUR 4.13 Percentage afgestudeerden met een relatief hoog inkomen 5 jaar na afstuderen $\mathrm{x}=\mathrm{FdGW}, 0=\mathrm{FdG}$

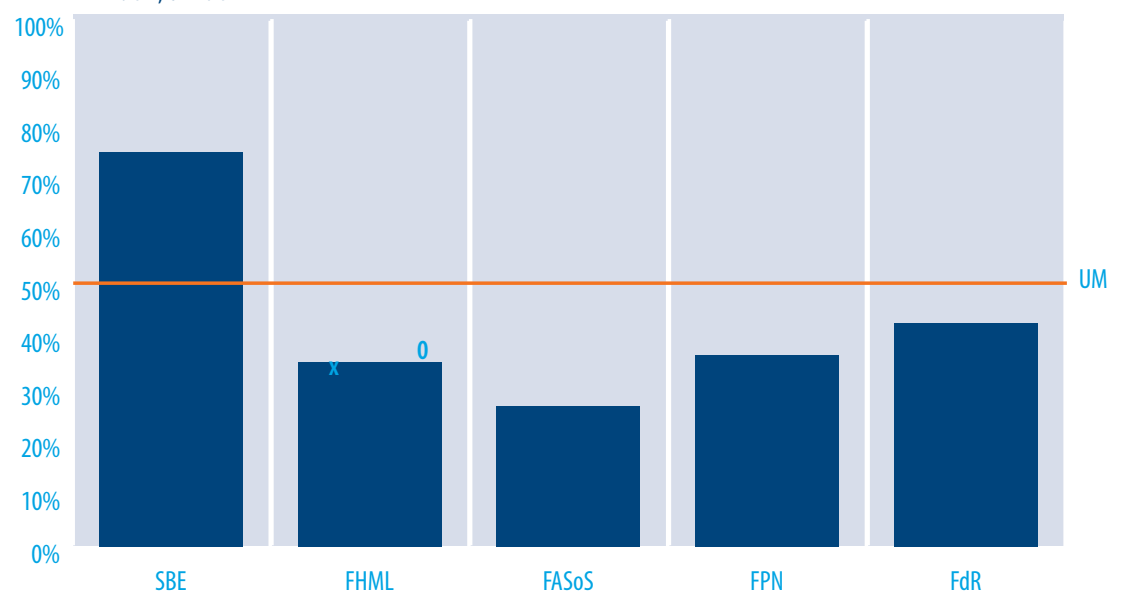

Bron: UM scanner 2015

In de trend tussen 2000 en 2015 missen we een observatiejaar, zoals te zien is in Figuur 4.14, doordat de vraag naar het inkomen in 2014 op een onvergelijkbare manier is gesteld. Uit de figuur blijkt dat er een daling heeft plaatsgevonden in de hoogte van het inkomen, vergeleken met het mediaan inkomen van het cohort 2009/2010 laten alle voorgaande jaren een hoger percentage zien dat boven deze mediaan uitkomt. Dit percentage ontwikkelt zich met een paar kleine golven met onder andere al een kleine daling in 2005. 
Alleen voor SBE geldt dat het percentage afgestudeerden met een relatief hoog inkomen vrij stabiel is. Voor FASoS is alleen informatie beschikbaar sinds 2010, in de laatste jaren is het aandeel FASoS afgestudeerden met een hoog inkomen sterk afgenomen. Terwijl in 2010 bijna twee op de drie FASoS afgestudeerden een baan met een relatief hoog inkomen had, had in 2015 minder dan één op de drie afgestudeerden een dergelijke baan. Onder de FdR afgestudeerden zien we tussen 2001 en 2008 een toename in de kans op een baan met een relatief hoog inkomen, maar sinds 2008 juist een afname. Onder FHML afgestudeerden ligt het percentage veelal rondom de $60 \%$, met een relatief laag percentage afgestudeerden met een baan met een relatief hoog inkomen in 2013 en 2015. Binnen FPN fluctueert het percentage over de jaren flink.

\section{FIGUUR 4.14 Trend in percentage met een relatief hoog inkomen}

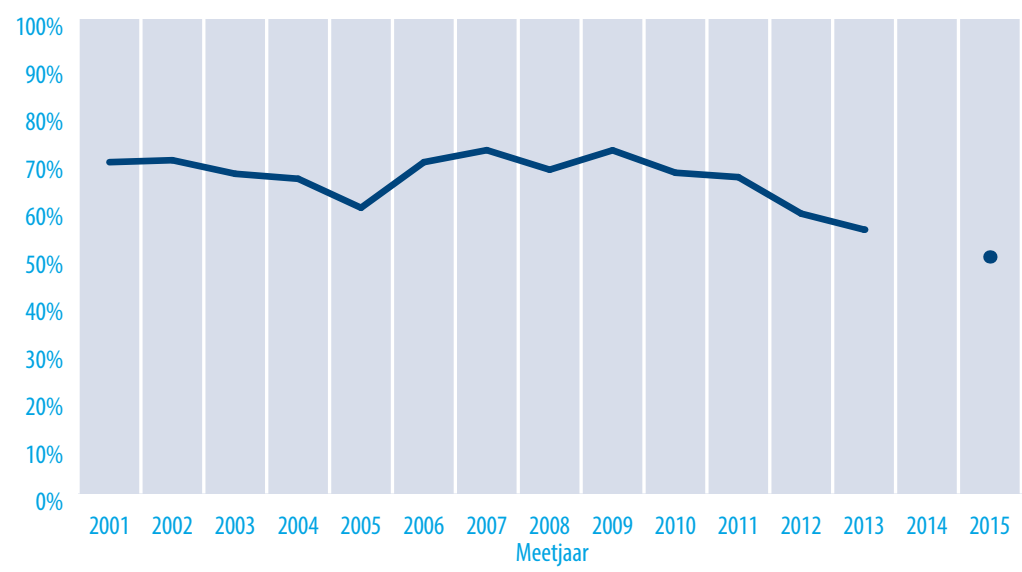

Bron: UM scanner 2001-2015

FIGUUR 4.15 Percentage met een relatief hoog inkomen 5 jaar na afstuderen, landelijke vergelijking UM Vergelijkbaar nationaal

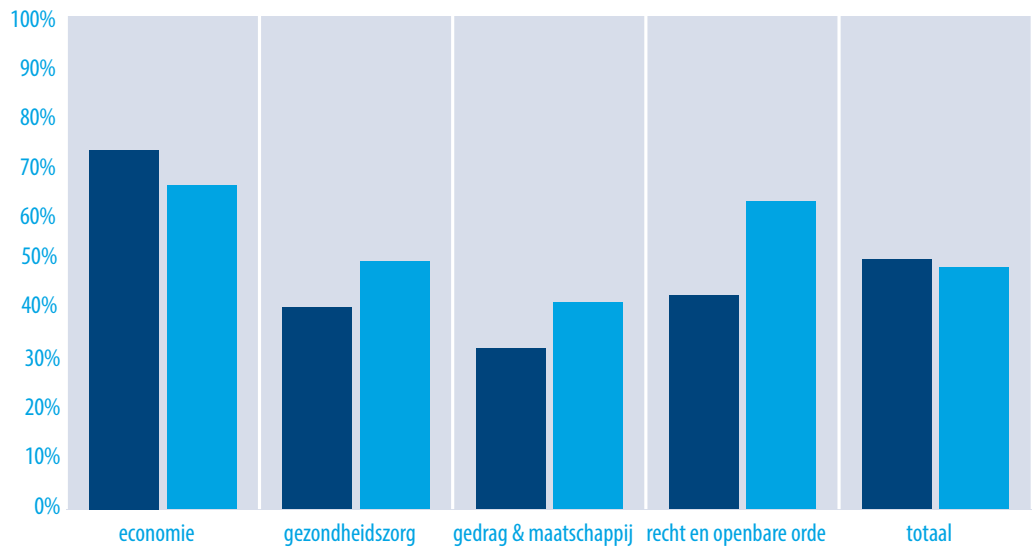

Bron: UM scanner 2015, wo T+5 2015 
De landelijke inkomensvergelijking van cohort 2009/2010 is te zien in Figuur 4.15. Het inkomen voor UM afgestudeerden is vergelijkbaar met dat van de afgestudeerden van alle Nederlandse universiteiten. Alleen binnen het HOOP-gebied gezondheidszorg blijkt dat UM afgestudeerden significant minder vaak een relatief hoog inkomen hebben vergeleken met afgestudeerden van andere Nederlandse universiteiten.

\subsection{Tevredenheid huidige functie}

De baantevredenheid (o.a. Allen \& Coenen, 2011) kan als subjectieve indicator van 'employability' worden beschouwd. Deze indicator sluit aan op de 'employability'definitie van Yorke (2006), die stelt dat het niet alleen gaat om het verkrijgen van een baan, maar onder andere ook om het hebben van een baan waarin men zich prettig voelt. In Figuur 4.16 geven we het percentage UM-afgestudeerden weer dat aangegeven heeft tevreden te zijn met de huidige functie. Medisch afgestudeerden zijn het meest tevreden met de huidige functie, $77 \%$ is tevreden met de baan. Dit ondanks het relatief lage loon en de relatief kleine kans op een vaste baan. Voor afgestudeerden van SBE en FdR ligt het percentage tevredenen rond het gemiddelde van de UM, ongeveer $69 \%$. FASoS valt op door de lage tevredenheid onder afgestudeerden, $48 \%$ van hen is tevreden met de huidige functie. Dit zou wederom te maken kunnen hebben met de relatief hoge kans die FASOS afgestudeerden hebben op een baan buiten de gekozen richten én onder universitair niveau.

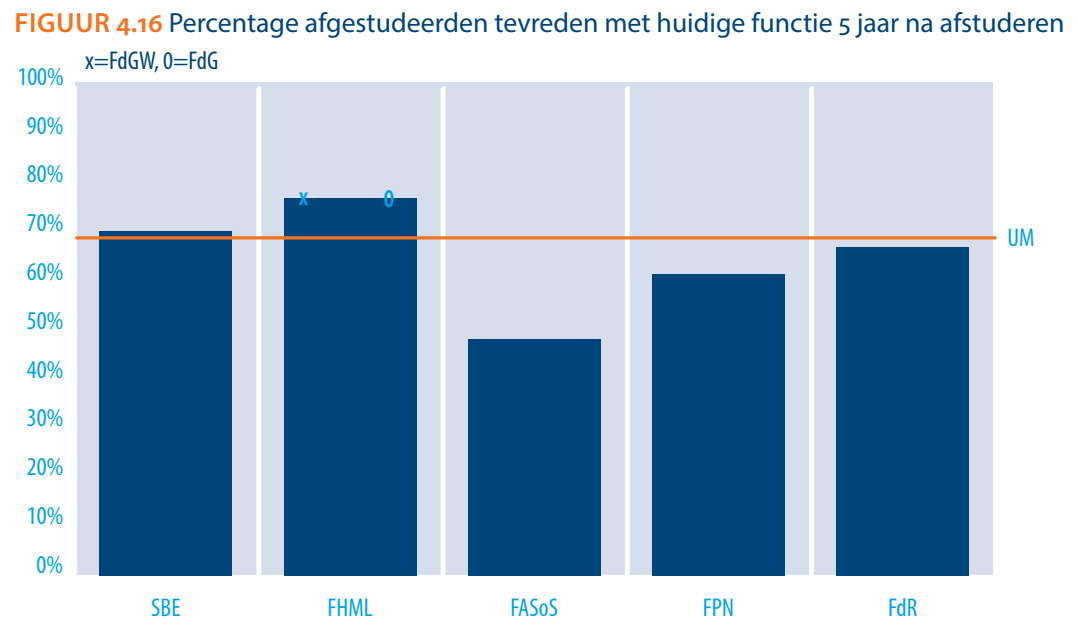

Bron: UM scanner 2015

De tevredenheid met de huidige functie onder UM-afgestudeerden is niet veel veranderd door de jaren heen. Wel is er een lichte daling te zien in Figuur 4.17, het percentage tevreden afgestudeerden is in een tijdsbestek van 15 jaar met ongeveer 10\%-punt afgenomen. Overigens missen we net als voor het relatieve inkomen ook hier observaties voor 2014. 
Onder SBE en FdR afgestudeerden is er ook weinig fluctuatie zichtbaar. Ongeveer drie kwart van de afgestudeerden van deze faculteiten zijn tevreden met de baan. De enige uitzondering hierop is het hoge percentage FdR afgestudeerden dat in 2009, vijf jaar na afstuderen, aangeeft tevreden te zijn met hun huidige functie (93\%). Binnen FHML was een dalende trend waarneembaar tussen 2001 en 2008, maar er is sinds 2009 sprake van licht herstel. De mate van tevredenheid onder FPN afgestudeerden fluctueert door het lage aantal observaties fors.

FIGUUR 4.17 Trend in percentage afgestudeerden tevreden met huidige functie

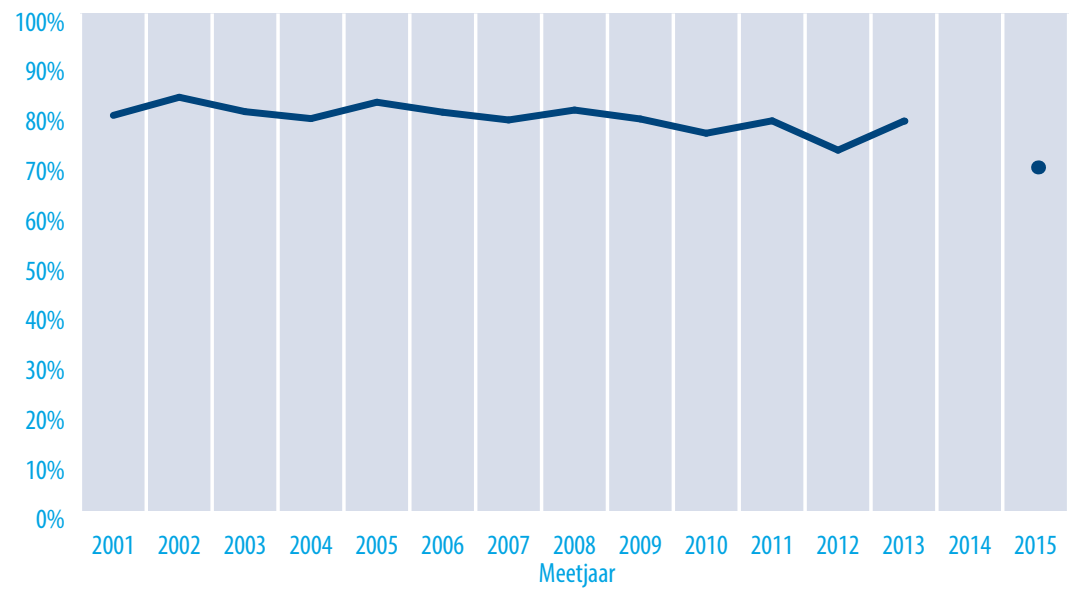

Bron: UM scanner 2001-2015

FIGUUR 4.18 Percentage afgestudeerden tevreden met huidige functie 5 jaar na afstuderen, landelijke vergelijking

UM Vergelijkbaar nationaal

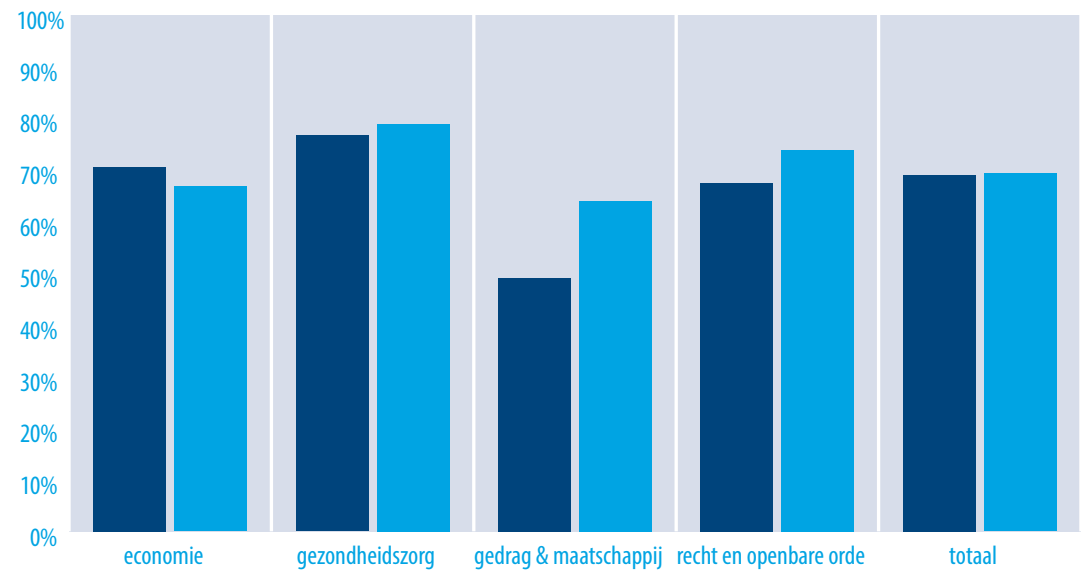

Bron: UM scanner 2015, wo T+5 2015. 
De landelijke vergelijking van de tevredenheid geven we weer in Figuur 4.18. De tevredenheid onder UM afgestudeerden ligt op hetzelfde niveau als landelijk. Alleen binnen gedrag en maatschappij is een significant verschil gevonden tussen afgestudeerden van de UM en die van andere Nederlandse universiteiten samengepakt: het percentage tevreden afgestudeerden van de UM ligt bijna 15\%-punt lager.

\subsection{Carrièremogelijkheden huidige functie}

Een andere subjectieve maatstaf voor 'employability' is de mate waarin men carrièremogelijkheden heeft binnen de huidige functie. Immers, afgestudeerden staan aan het begin van hun carrière en het is erg aannemelijk dat zij niet hun hele carrière binnen dezelfde functie zullen blijven werken. Figuur 4.19 laat het percentage afgestudeerden zien dat naar eigen zeggen goede carrièremogelijkheden heeft binnen de huidige functie vijf jaar na afstuderen. Afgestudeerden van SBE en FHML zijn positiever over de carrièreperspectieven dan het UM-gemiddelde; meer dan $60 \%$ van de afgestudeerden van deze faculteiten geeft aan dat deze goed zijn. Binnen de medische faculteit zijn het vooral de afgestudeerden van FdG die positief zijn. Bij de andere drie faculteiten is de meerderheid van de afgestudeerden niet heel positief over de mogelijkheden binnen de huidige functie. Bij FASoS is minder dan $40 \%$ van de afstudeerders positief over de carrièremogelijkheden. Ook voor FPN en FdR geldt dat minder dan de helft van de afgestudeerden (ongeveer 45\%) hun carrièreperspectieven als goed waardeert.

FIGUUR 4.19 Percentage afgestudeerden met goede carrièremogelijkheden binnen huidige functie 5 jaar na afstuderen

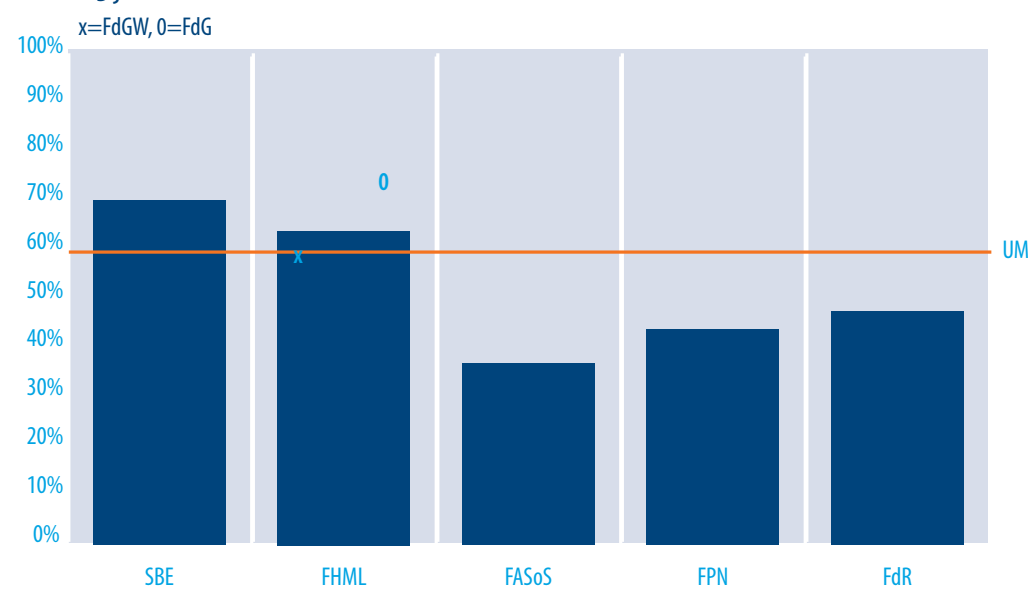

Bron: UM scanner 2015

Zoals we kunnen zien in Figuur 4.20 is het oordeel van de UM-afgestudeerden over de eigen carrièremogelijkheden binnen de huidige functie nauwelijks veranderd tussen 2000 en 2015. Daarbij is er ook in de tussentijd weinig variatie waarneembaar. 
Voor FHML geldt ook dat er nauwelijks fluctuatie is in het oordeel van de afgestudeerden over de carrièremogelijkheden. Ook bij SBE is de variatie gering, hoewel er wel een kleine stijging waarneembaar is tot 2006 met een daaropvolgende afname tot 2012. De afgestudeerden van FdR en FPN percipiëren meer ups en downs in de carrièremogelijkheden vijf jaar na afstuderen. Tussen 2007 en 2013 is er onder FdR afgestudeerden sprake van een omgekeerde U-trend en voor FPN afgestudeerden is er tussen 2009 en 2013 juist een U-trend te zien.

\section{FIGUUR 4.20 Trend in percentage met goede carrièremogelijkheden binnen huidige functie}

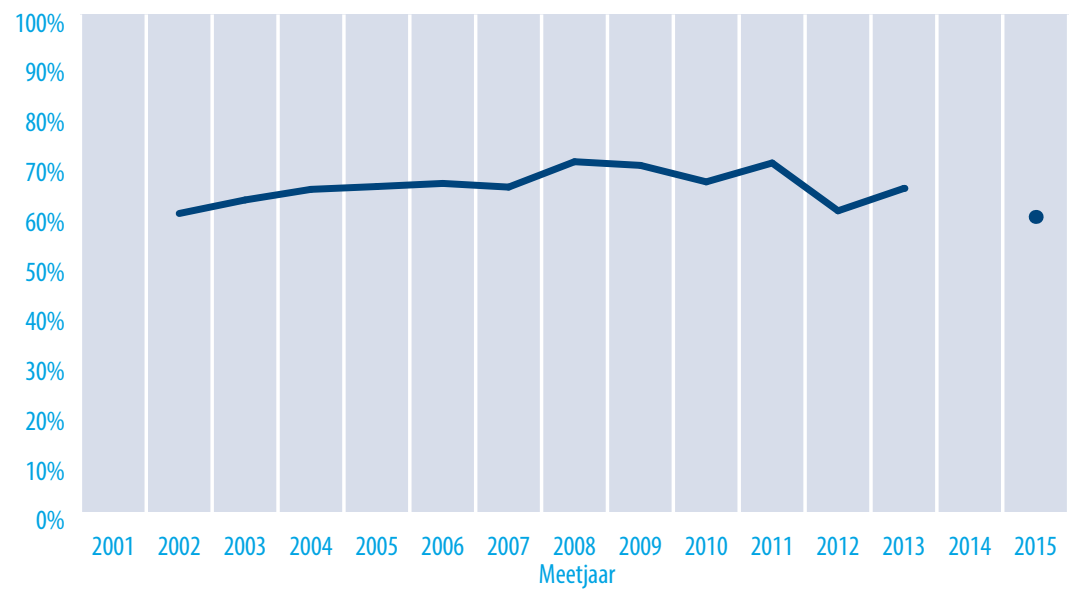

Bron: UM scanner 2001-2015

FIGUUR 4.21 Percentage afgestudeerden met goede carrièremogelijkheden binnen huidige functie 5 jaar na afstuderen landelijke vergelijking

—UM Vergelijkbaar nationaal

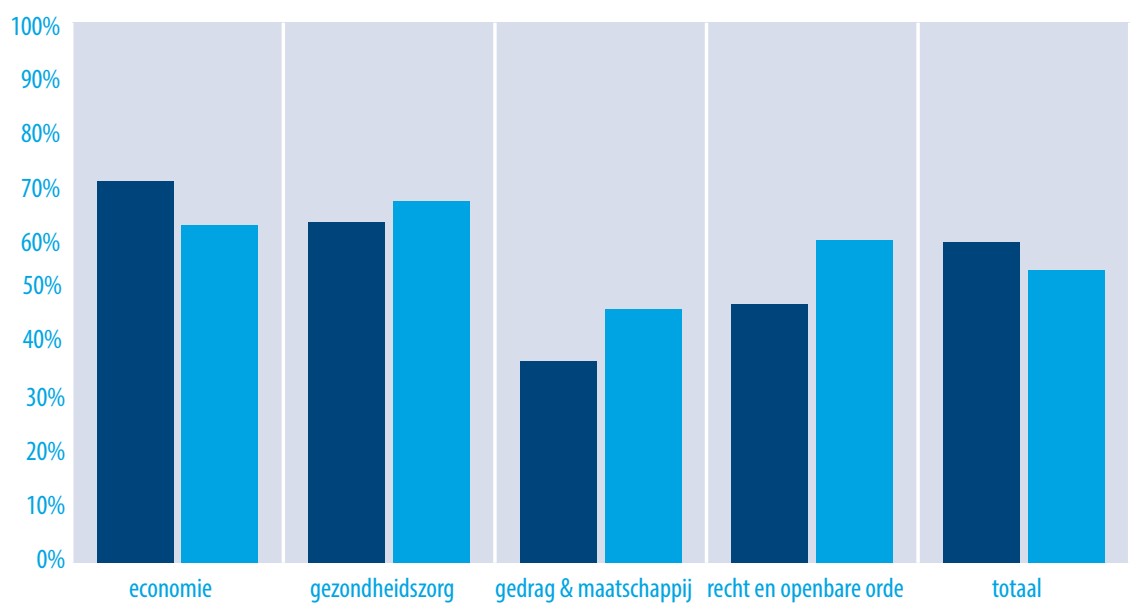

Bron: UM scanner 2015, wo T+5 2015 
Uit de landelijke vergelijking in Figuur 4.21 lijkt dat het aantal UM-afgestudeerden met een positief oordeel over de carrièremogelijkheden hoger ligt dan bij andere universiteiten. Echter, dit verschil is slechts zwak significant. Er blijken geen significante verschillen binnen de verschillende HOOP-gebieden.

\subsection{Employability indicatoren per faculteit}

In de afgelopen subhoofdstukken 4.1-4.7 hebben we in detail de verschillende employability indicatoren besproken. In dit hoofdstuk vatten we de indicatoren per faculteit nog even samen. We gaan hierbij in op vijf 'employability' indicatoren voor het afstudeercohort 2009/2010 en beschrijven de ranking van de indicatoren ten opzichte van andere faculteiten. Het gaat hierbij om een baan op universitair niveau, een baan in eigen vakgebied, een baan met een relatief hoog inkomen, de tevredenheid met de huidige functie en het oordeel over de carrièremogelijkheden binnen de huidige functie. Deze ranking plaatst faculteit specifieke cijfers in perspectief en nodigt zowel beleidsmakers als docenten uit tot het formuleren van actiepunten.

FIGUUR 4.22 'Employability' indicatoren per faculteit

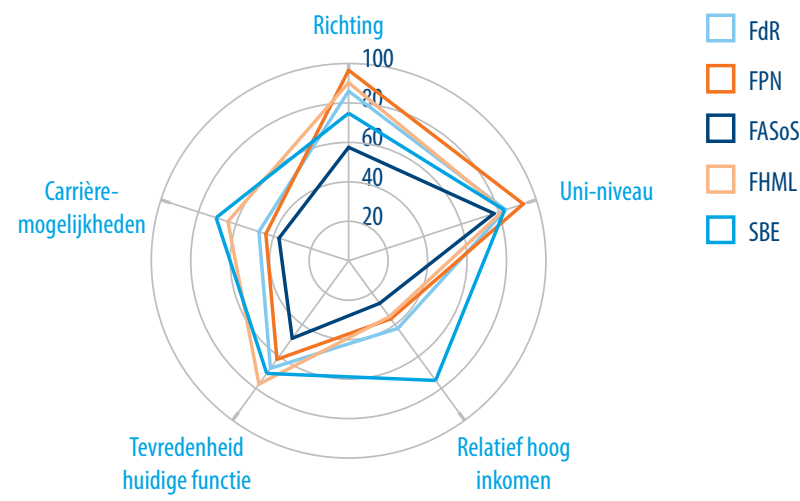

Bron: UM scanner 2015

Het werkloosheidspercentage ligt vijf jaar na afstuderen onder SBE afgestudeerden het laagste met maar 1,5\%. Op de meeste 'employability' indicatoren in Figuur 4.22 scoren SBE afgestudeerden vergelijkbaar met andere faculteiten ( $83 \%$ heeft een baan op wo-niveau en $71 \%$ is tevreden met de huidige functie), soms iets hoger zoals bij het oordeel over de carrièremogelijkheden (71\% tevreden) en soms wat lager zoals het werken binnen eigen vakgebied (75\%). Aanmerkelijk beter scoren ze op het vinden van een baan met een relatief hoog inkomen (75\%) waarin ze duidelijk uitsteken boven de andere UM faculteiten. 
Met een werkloosheidspercentage van 5,2\% zijn FHML afgestudeerden relatief vaak werkloos vergeleken met de andere faculteiten. Voor de overige indicatoren scoren de FHML afgestudeerden juist relatief goed zoals te zien is in Figuur 4.22. 90\% heeft een baan binnen het vakgebied, $83 \%$ heeft een baan op wo-niveau en $64 \%$ ervaart goede carrièremogelijkheden in de huidige baan. Met betrekking tot de baantevredenheid (77\% is tevreden) scoren ze zelfs het hoogste vergeleken met de andere faculteiten. FHML afgestudeerden hebben wel een relatief lage kans op het vinden van een goedbetaalde baan (35\%).

FASoS afgestudeerden hebben de grootste kans op werkloosheid. Desalniettemin heeft slechts $6,7 \%$ van de afgestudeerden vijf jaar na afstuderen geen baan gevonden. Hiermee geldt ook voor FASoS dat meer dan 9 van de 10 afgestudeerden vijf jaar na afstuderen een baan gevonden heeft. Dit neemt niet weg dat zij op de andere 'employability' indicatoren ook wat achter lopen op de andere faculteiten. Het blijkt voor FASoS afgestudeerden niet gemakkelijk een baan in hun vakgebied (58\%) of een baan met een relatief hoog salaris ( $27 \%$ ) te vinden. Dit weerspiegelt waarschijnlijk ook hun relatief lage baantevredenheid (49\%) en de relatief beperkte carrièremogelijkheden (37\%) die zij binnen hun huidige functie ervaren.

Vijf jaar na afstuderen is het werkloosheidspercentage onder FPN alumni slechts $2.5 \%$. In vergelijking tot de afgestudeerden van andere faculteiten scoort FPN relatief gezien erg hoog op het percentage afgestudeerden werkzaam op uni niveau (93\%) en binnen het vakgebied (97\%). Opvallend genoeg is het percentage afgestudeerden met goede carrièremogelijkheden (44\%), een baan waarmee zij tevreden zijn (62\%) en een baan met een relatief hoog inkomen (36\%) laag vergeleken met afgestudeerden van andere faculteiten.

Ook de FdR alumni zijn relatief weinig werkloos; het werkloosheidspercentage ligt vijf jaar na afstuderen op 1,8\%. Terwijl de kans op een baan op wo-niveau (84\%) of binnen het vakgebied (86\%) erg hoog is voor afgestudeerden van FdR, percipieert minder dan de helft van hen goede carrièremogelijkheden. Ongeveer 2 op de 3 afgestudeerden van FdR is tevreden met hun huidige functie. Wat betreft inkomen lopen ze achter op SBE afgestudeerden maar ze hebben we het hoogste inkomen onder de overige UM alumni $(42 \%)$.

\subsection{Employability indicatoren naar master opleiding}

Doordat een groot deel van de masteropleidingen relatief klein in omvang zijn, kunnen we geen 'employability' indicatoren op het niveau van de master opleidingen weergeven voor het meest recente cohort. Op basis van het trendbestand kunnen we wél 'employability' indicatoren laten zien voor master opleidingen door de laatste vijf cohorten samen te voegen. In Tabel A2 in de bijlage is een overzicht gegeven van de 'employability' indica-toren naar masteropleiding. Verder geeft Figuur 4.23 de werkloosheidpercentages weer en geven de figuren 4.24 tot en met 4.29 op facultair niveau weer hoe de 
master opleidingen scoren op vijf van de employability indicatoren. Het vinden van een vaste baan is in deze figuren niet opgenomen omdat deze cijfers eerder een resultaat zijn van de huidige flexibilisering van de arbeidsmarkt dan dat ze aangeven hoe goed iemand terecht is gekomen. De percentages zijn overigens wel terug te vinden in Tabel A2. We hebben alleen die opleidingen meegenomen waar in het meest recente afstudeercohort 2009/2010 nog afgestudeerden waren en waar we minimaal 20 observaties voor hebben. Met andere woorden, oude masteropleidingen die niet langer bestonden in 2009/2010 hebben we niet opgenomen in dit subhoofdstuk.

\section{FIGUUR 4.23 Werkloosheidpercentage naar masteropleiding}

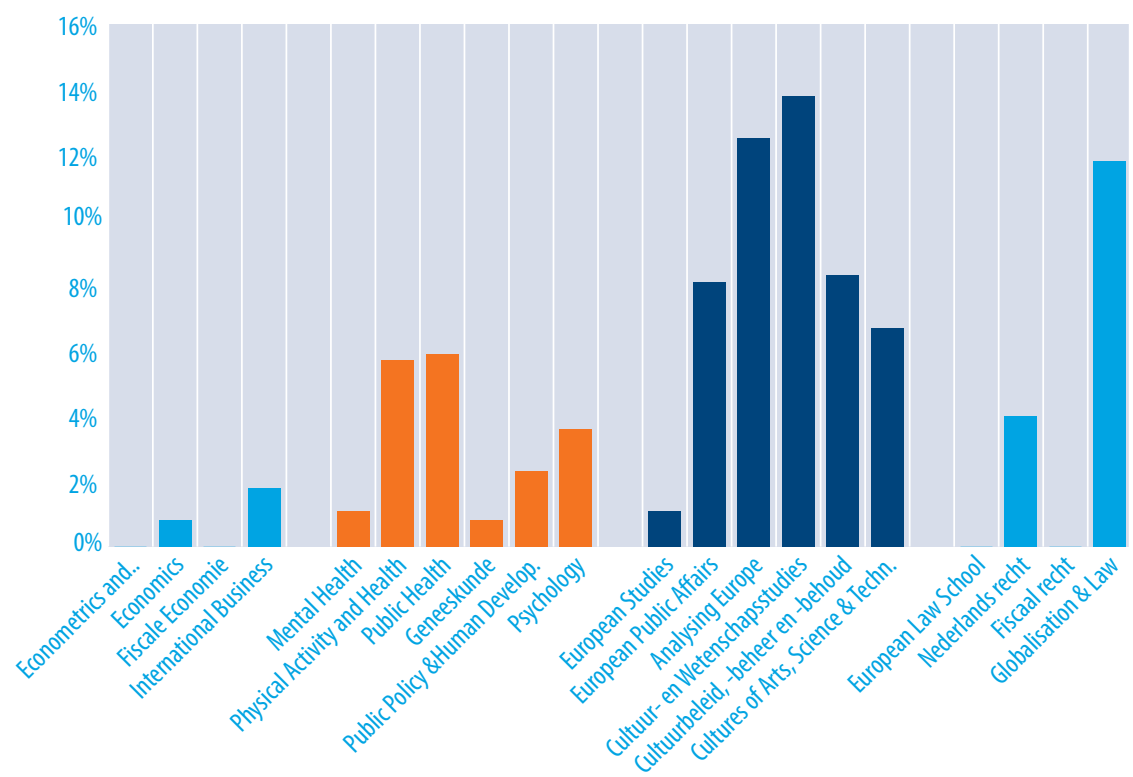

Bron: UM scanner 2011-2015

In de figuren zijn interessante verschillen waarneembaar tussen de opleidingen binnen een faculteit. Allereerst zijn er binnen SBE lage werkloosheidscijfers te zien voor de verschillende masteropleidingen. Voor de opleidingen Econometrie en operationele research en Fiscale Economie is er zelfs geen enkele afgestudeerde werkloos. Daarnaast valt het op dat alle afgestudeerden van econometrie en operationele research een baan op universitair niveau hebben terwijl voor de afgestu $\neg$ deerden van de andere masteropleidingen geldt dat zij ongeveer $85 \%$ kans hebben op een baan op wo-niveau. Een vergelijkbaar beeld is waarneembaar voor het vinden van een baan binnen hun vakgebied, het oordeel over de eigen carrièremogelijkheden en de tevredenheid met de huidige functie. Voor deze indicatoren steken de afgestudeerden van econometrie en operationele research er relatief gezien bovenuit. Enkel met betrekking tot het percentage relatief hoog inkomen scoren afgestudeerden van econometrie en operationele 
research slechter. Voor deze 'employability' indicator scoren juist de IB-afgestudeerden beter. Afgestudeerden van Fiscal Economics en Economics scoren vergelijkbaar op de vijf'employability' indicatoren.

FIGUUR 4.24 'Employability' indicatoren naar masteropleiding binnen SBE

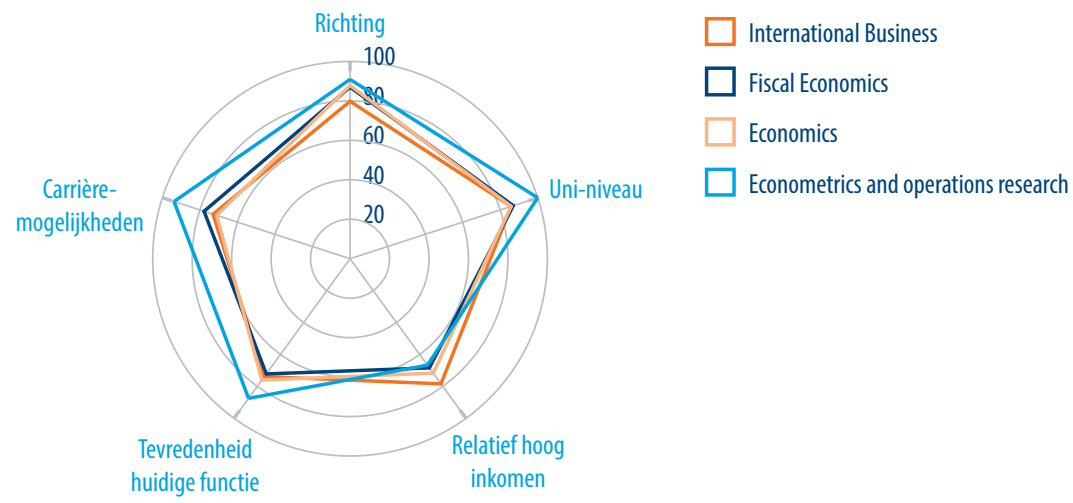

Bron: UM scanner 2011-2015

Binnen FHML zijn het overduidelijk de afgestudeerden van geneeskunde die goed scoren op de 'employability' indicatoren, zoals te zien is in Figuur 4.25. Bijna alle afgestudeerden vinden een baan binnen hun vakgebied en op universitair niveau. De enige indicatoren waarop afgestudeerden van geneeskunde slechter scoren dan afgestudeerden van andere opleidingen binnen FHML zijn het relatief hoge inkomen en het vinden van een vaste baan(niet in Figuur 4.25 opgenomen). Onder de overige FHML masters scoren afgestudeerden van Mental Health het beste op de 'employability' indicatoren, in het geval van een baan met een relatief hoge inkomen zelfs beter dan afgestudeerden van geneeskunde. Met betrekking tot werkloosheid zijn het ook geneeskunde en Mental Health die het best scoren binnen FHML. Afgestudeerden van Physical Activity and Health en Public Health hebben te maken met een relatief hoger werkloosheidspercentage. 
FIGUUR 4.25 'Employability' indicatoren naar masteropleiding binnen FHML

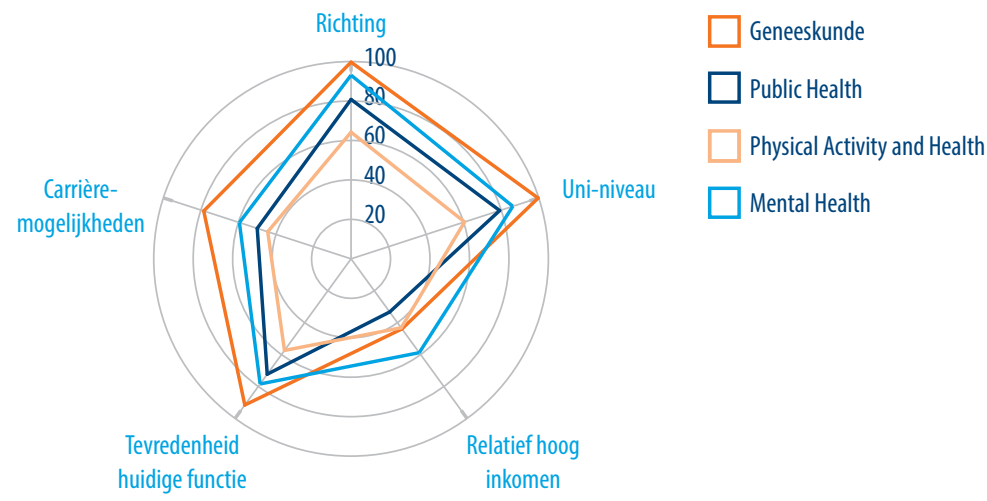

Bron: UM scanner 2011-2015

Afgestudeerden van Psychology scoren wisselend op de 'employability' indicatoren. Enerzijds is een aanzienlijk deel van de afgestudeerden in staat een baan te vinden in eigen vakgebied en op universitair niveau, respectievelijk $80 \%$ en $88 \%$. Anderzijds is maar $38 \%$ van de afgestudeerden in staat een baan te vinden met een relatief hoog inkomen. Daarbij zijn ze niet al te positief over de eigen carrièremogelijkheden aangezien maar $51 \%$ van de Psychology afgestudeerden aangeeft dat deze goed zijn. Verder is $3,6 \%$ van de afgestudeerden vijf jaar na afstuderen werkloos.

FIGUUR 4.26 'Employability' indicatoren naar masteropleiding binnen FPN

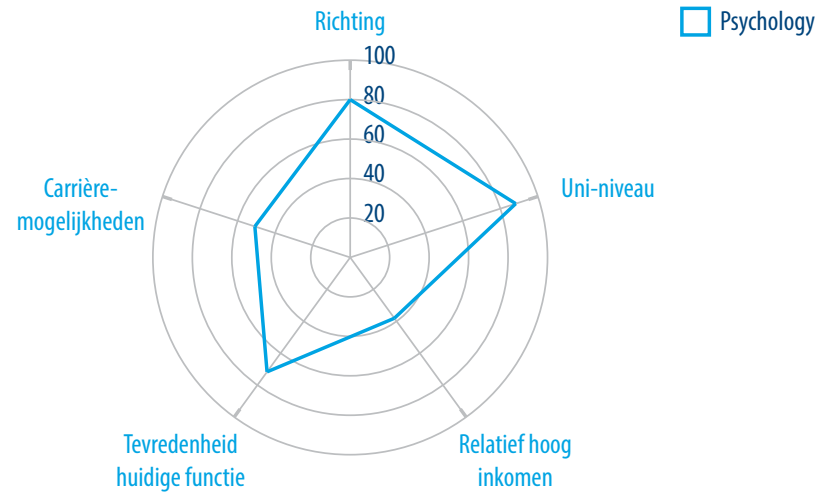

Bron: UM scanner 2011-2015

Waar we in de voorgaande paragrafen niet in konden gaan op de FHS, is er wel een masteropleiding binnen deze faculteit waar we over vijf jaar genomen wél uitspraken over kunnen doen. Afgestudeerden van de masteropleiding public policy and human development hebben vijf jaar na afstuderen $2 \%$ kans op werkloosheid. Bovendien werkt 
van hen bijna $80 \%$ in hun vakgebied en ruim $95 \%$ heeft een baan op wo-niveau. Bijna $60 \%$ heeft een vaste baan en $56 \%$ heeft een relatief hoog inkomen. Twee derde van de afgestudeerden van de masteropleiding public policy and human development is tevreden met hun baan en bijna evenveel afgestudeerden schatten hun carrièremoge $\neg$ lijkheden goed in.

FIGUUR 4.27 'Employability' indicatoren naar masteropleiding binnen FHS

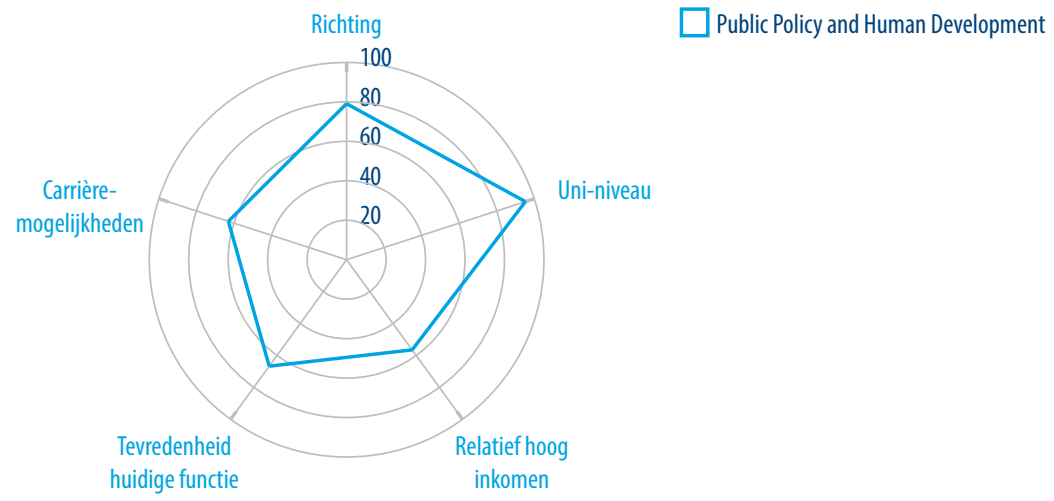

Bron: UM scanner 2011-2015

Binnen FASoS zijn er grote verschillen met betrekking tot de 'employability' indicatoren. Zo is de werkloosheid onder afgestudeerden van European studies met 1\% laag (ook verge $\neg$ leken met het UM gemiddelde), terwijl de werkloosheid onder de masteropleidingen Analysing Europe en cultuur- en wetenschapstudies juist erg hoog zijn (13 en $14 \%$ respec $\neg$ tievelijk). Deze twee studies scoren ook het laagste op de kans op een baan binnen het vakgebied. De kans op een baan op wo-niveau is hoog voor afgestudeerden van European studies, European public affairs en Analysing Europe. Bij geen van de masteropleidingen binnen FASoS is de kans op een relatief hoog inkomen hoog te noemen, maar voor de opleiding cultures of arts, science and technology is deze kans, met $9 \%$, ronduit laag. Afgestudeerden van European public affairs zijn onder de FASoS afgestudeerden het minst tevreden met hun baan. Goede carrièremogelijkheden zijn vrij gelijk verdeeld binnen de opleidingen behorend bij FASoS. De enige uitzondering is European public affairs, waar slechts $45 \%$ hun carrieremogelijkheden als goed waardeert. 
FIGUUR 4.28 'Employability' indicatoren naar masteropleiding binnen FASoS

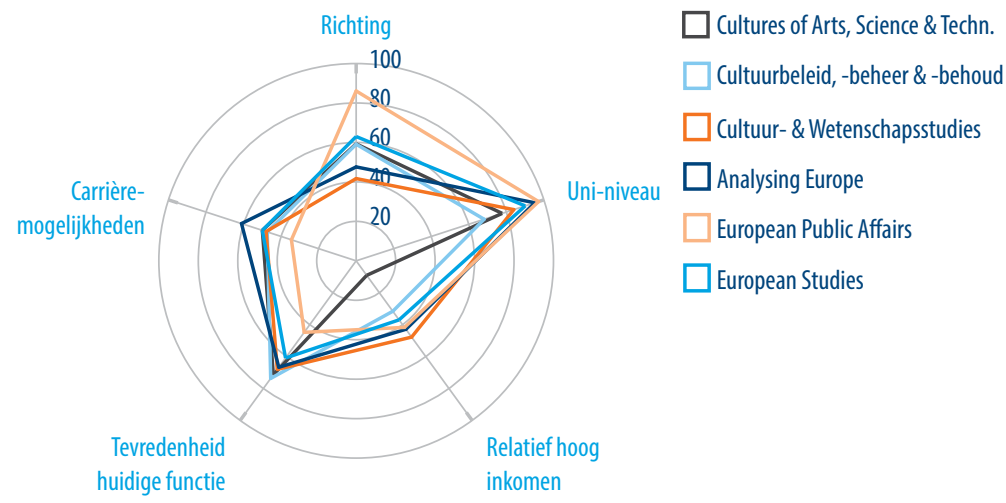

Bron: UM scanner 2011-2015

Binnen de rechtenfaculteit zijn de verschillen het grootst voor werkloosheid en de kans op een relatief hoog inkomen. Terwijl geen van de afgestudeerden van de European law school en van de masteropleiding fiscaal recht werkloos is, geldt onder de afge $\neg$ studeerden van globalisation and law dat ruim één op de tien werkloos is. Als men een baan heeft verschillen de kansen op een baan op wo-niveau en binnen het vakgebied niet veel. De kans op een vaste baan en op een baan met een relatief hoog inkomen is het hoogste onder afgestudeerden van fiscaal recht ( $86 \%$ en $83 \%$ respectievelijk) en het kleinste onder de afgestudeerden van de European law school (73\% en $39 \%$ respectie $\neg$ velijk). Al met al is het waarschijnlijk ook niet verwonderlijk dat afgestudeerden van de European law school het minst tevreden zijn met hun baan en dat zij de carrièremo $\neg$ gelijkheden het minst positief inschatten.

FIGUUR 4.29 'Employability' indicatoren naar masteropleiding binnen FdR

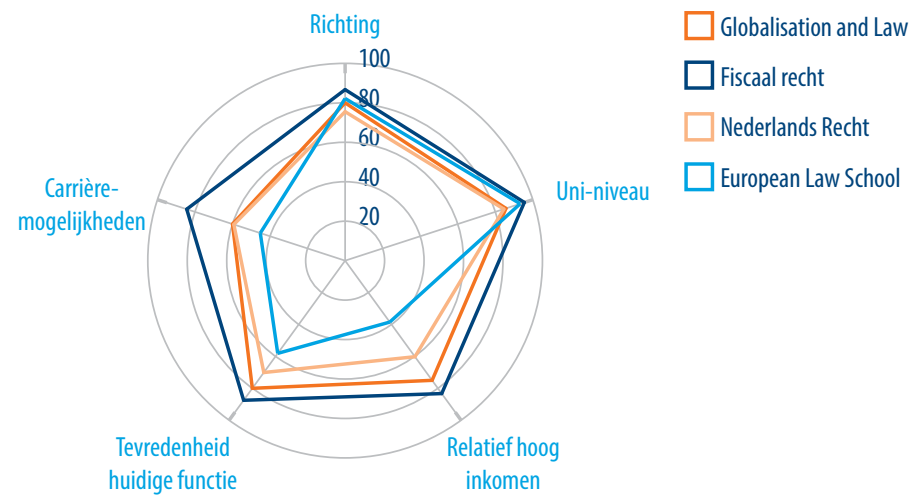

Bron: UM scanner 2011-2015 



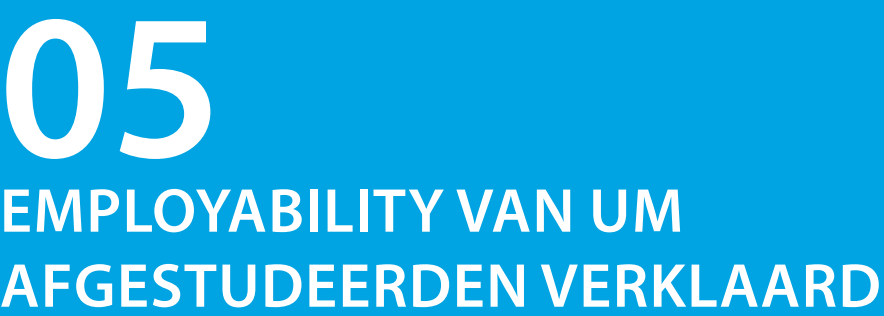

$\mathrm{Nu}$ we de 'employability' van UM-afgestudeerden op beschrijvende wijze in kaart hebben gebracht besteden we in dit hoofdstuk aandacht aan het verklaren van de 'employability' van UM-afgestudeerden. In de analyses voeren we een aantal regressies (Lineair Probability Models) uit met als doel te laten zien welke eigenschappen van afgestudeerden en opleidingen bijdragen aan 'employability'. Daarnaast houden we expliciet rekening met het jaar van afstuderen, omdat uit de literatuur is gebleken dat naast kenmerken van de afgestudeerden en de opleiding, ook de context waarin men afstudeert - de conjunctuur - zeer bepalend is, met name voor de harde 'employability' maatstaven (o.a. Brown e.a., 2016). We groeperen de gegevens van de meest recente vijf dataverzamelingsgolven. We verklaren de eerder in het rapport aan bod gekomen zeven maatstaven voor 'employability' zowel vijf als tien jaar na afstuderen. Als aanvullende analyse kijken we of de resultaten hetzelfde blijven als we de analyse op landelijk niveau uitvoeren.

\subsection{De rol van persoonsfactoren en faculteit}

In Tabel 5.1 en Tabel 5.2 worden twee typen determinanten gerelateerd aan de objectieve indicatoren voor 'employability' vijf en tien jaar na afstuderen, respectievelijk. Het gaat hier om persoonsfactoren en de faculteit waaraan men is afgestudeerd. De referentiefaculteit in de analyses betreft SBE omdat dit één van de grotere UM faculteiten is. Met betrekking tot de kans op werkloosheid vijf jaar na afstuderen zien we in Tabel 5.1 dat een relatief hoge leeftijd correleert met een hogere werkloosheid. UM-afgestudeerden met een niet-Nederlandse nationaliteit hebben ook te maken met een grotere kans op werkloosheid. Overigens zijn de verschillen naar leeftijd en etniciteit niet meer significant tien jaar na afstuderen. Op facultair niveau zien we dat afgestudeerden van SBE vijf jaar na afstuderen een significant kleinere kans hebben om werkloos te zijn vergeleken met de andere faculteiten. Dit komt overeen met de beschrijvende statistieken uit paragraaf 4.1. Tien jaar na afstuderen blijkt er enkel een significant grotere kans op werkloosheid voor afgestudeerden van FASoS overeind.

Hoewel afgestudeerden met een niet-Nederlandse nationaliteit vijf jaar na afstuderen vaker werkloos zijn dan Nederlanders, blijkt uit Tabel 5.1 dat ze wel een grotere kans hebben om een baan in de gekozen richting te vinden. Deze kans is ook groter voor gepromoveerde afgestudeerden, wat in de lijn der verwachting zit aangezien 
een promotie nog meer focus op een specifiek onderwerp vereist. Als we kijken naar de verschillen tussen faculteiten dan blijken SBE afgestudeerden een grotere kans te hebben om een baan in de eigen richting te vinden. Alleen ten opzichte van FHML is er geen significant met SBE. De determinanten van een baan in de gekozen richting 10 jaar na afstuderen komen vrijwel overeen met de determinanten vijf jaar na afstuderen.

Er zijn geen significante verschillen tussen faculteiten in de kans om een baan op universitair niveau te vinden. Echter zien we wederom dat een niet-Nederlandse nationaliteit en een afgerond promotietraject de kans vergroten. Daarnaast zien we dat vrouwen een kleinere kans hebben op het vinden van een baan op universitair niveau. Ook 10 jaar na afstuderen zien we dat vrouwen nog steeds een kleinere kans op een baan op wo-nivau hebben. Verder speelt de leeftijd een rol, hoe ouder de afgestudeerde hoe kleiner de kans wordt op een baan op universitair niveau.

Het vinden van een vaste baan is positief gecorreleerd met leeftijd; hoe ouder de afgestudeerde hoe hoger de kans op een vaste baan vijf jaar na afstuderen. Tevens zien we net zoals in het vorige hoofdstuk dat afgestudeerden van SBE een grotere kans hebben op een vaste baan. De kans op een vaste baan is echter fors kleiner voor afgestudeerde die een promotietraject hebben afgerond. Dit heeft waarschijnlijk te maken met de tenure-track en postdoc posities die gepromoveerden die in de wetenschap blijven hebben. Het is bekend dat er in de academische wereld relatief vaak sprake is van tijdelijke contracten. Ook tien jaar na afstuderen zien we dat gepromoveerden minder vaak een vaste baan hebben, hoewel het verschil kleiner is geworden. Verder blijken nietNederlanders tien jaar na afstuderen vaker een vaste baan te hebben dan Nederlanders.

Naarmate de leeftijd van afgestudeerden hoger ligt, des te groter is de kans op een baan met een relatief hoog inkomen vijf jaar na afstuderen; tien jaar na afstuderen is er geen verschil meer naar leeftijd. Afgestudeerden van SBE hebben eveneens een grotere kans op een baan met een relatief hoog inkomen, zowel vijf als tien jaar na afstuderen. Vrouwen en gepromoveerden hebben een kleinere kans op een baan met een relatief hoog inkomen, wat tevens uit de analyse 10 jaar na afstuderen naar voren komt. De observatie dat vrouwen een gemiddeld genomen een lager loon hebben dan mannen is in lijn met de landelijke statistieken en is daarmee niet specifiek voor (recent) afgestudeerden (CBS 2016). Uit een CBS-studie (2016) volgt zelfs dat het loonverschil tussen mannen en vrouwen toeneemt naarmate zij ouder worden. Immers naarmate werknemers ouder zijn, verdienen zij meer, waarbij mannen een sterkere loongroei doormaken dan vrouwen. Dit is in lijn met de bevindingen in Tabel 5.1 en 5.2 waarin te zien is dat de verschillen tussen mannen en vrouwen toenemen, vijf en tien jaar na afstuderen (grotere coëfficiënt).

Voor alle vijf indicatoren geldt dat verschillen tussen de meetjaren relatief klein zijn. Dit suggereert dat de invloed van de conjunctuur op de arbeidsmarktpositie van afgestudeerden vijf tot tien jaar na afstuderen vermoedelijk minder prominent is dan direct na afstuderen. Wel zien we uit Tabel 5.1 dat de kans op een vaste baan in 2015 signifi- 
cant kleiner is dan in het referentiejaar 2011. Dit is in lijn met de flexibilisering van de Nederlandse arbeidsmarkt (Gaalen e.a., 2013). Daarnaast zien we dat de relatieve lonen in 2015 significant lager zijn dan in 2011. Dit zagen we ook al in Figuur 4.2.

Het feit dat we de nodige verschillen in arbeidsmarktuitkomsten zien tussen Nederlanders en niet-Nederlanders kan te maken hebben met het feit dat zij vaak een andere markt bedienen dan de Nederlandse. De UM is een universiteit met een sterk internationaal profiel dat veel buitenlandse studenten aantrekt, waarvan een flink deel buiten Nederland gaat werken. Voor het meest recente UM afstudeercohort geldt dat $83 \%$ van de niet-Nederlanders vijf jaar na afstudern buiten Nederland werkt.

TABEL 5.1 Regressie output relatie tussen kernindicatoren en gegevens UM-afgestudeerden $\mathrm{T}+5$, 2011-2015

\begin{tabular}{|c|c|c|c|c|c|}
\hline & $\begin{array}{c}\text { (1) } \\
\text { Werkloosheid }\end{array}$ & $\begin{array}{c}\text { (2) } \\
\text { Gekozen richting }\end{array}$ & $\begin{array}{c}\text { (3) } \\
\text { Universitair niveau }\end{array}$ & $\begin{array}{c}\text { (4) } \\
\text { Vaste baan }\end{array}$ & $\begin{array}{c}\text { (5) } \\
\text { Relatief hoog } \\
\text { inkomen }\end{array}$ \\
\hline Vrouw & 0.150 & 0.0167 & $-4.168^{* *}$ & 0.560 & $-5.369^{*}$ \\
\hline Leeftijd & $0.180^{* *}$ & 0.194 & -0.227 & $0.951^{* * *}$ & $1.218^{* * *}$ \\
\hline Niet-NL nationaliteit & $1.788^{*}$ & $6.394^{* * *}$ & $8.305^{* * *}$ & 3.104 & -1.138 \\
\hline Gepromoveerd & 0.615 & $11.13^{* * *}$ & $10.79^{* * *}$ & $-31.10^{* * *}$ & $-11.98^{* * *}$ \\
\hline \multicolumn{6}{|c|}{ Faculteit (SBE is referentiegroep) } \\
\hline FHS & 0.590 & $-10.93^{*}$ & -4.804 & $-11.34^{*}$ & -9.716 \\
\hline FHML & $1.992^{*}$ & 2.715 & -0.730 & $-30.57^{* * *}$ & $-26.93^{* * *}$ \\
\hline FASOS & $4.849^{* * *}$ & $-26.92^{* * *}$ & -4.012 & $-20.91^{* * *}$ & $-36.62^{* * *}$ \\
\hline FPN & $2.958^{*}$ & $-9.014^{* *}$ & -0.159 & $-29.91^{* * *}$ & $-31.76^{* * *}$ \\
\hline $\mathrm{FdR}$ & $3.310^{* *}$ & $-6.529^{* *}$ & 0.0716 & $-8.650^{* *}$ & $-18.25^{* * *}$ \\
\hline \multicolumn{6}{|c|}{ Meetjaar (2011 is referentiegroep) } \\
\hline 2012 & 0.415 & -1.787 & 0.500 & 3.077 & -4.518 \\
\hline 2013 & -0.317 & 3.617 & $6.387^{* * *}$ & -4.437 & -3.966 \\
\hline 2014 & -0.637 & $4.582^{*}$ & 1.788 & -2.735 & \\
\hline 2015 & 0.891 & 4.421 & 1.534 & $-21.26^{* * *}$ & $-17.81^{* * *}$ \\
\hline Constante & $-7.205^{* *}$ & $70.61^{* * *}$ & $93.41^{* * *}$ & $38.51^{* * *}$ & $59.76^{* * *}$ \\
\hline Observaties & 2,085 & 1,796 & 1,788 & 1,780 & 1,258 \\
\hline R2 & 0.014 & 0.067 & 0.041 & 0.196 & 0.143 \\
\hline
\end{tabular}

Bron: UM scanner 2011-2015

Gecontroleerd voor bedrijfsgrootte in kolom 2-5

*** $\mathrm{p}<0.01,{ }^{* *} \mathrm{p}<0.05,{ }^{*} \mathrm{p}<0.1$ 
TABEL 5.2 Regressie output relatie tussen kernindicatoren en gegevens UM-afgestudeerden T+10, 2011-2015

\begin{tabular}{|c|c|c|c|c|c|}
\hline & $\begin{array}{c}\text { (1) } \\
\text { Werkloosheid }\end{array}$ & $\begin{array}{c}\text { (2) } \\
\text { Gekozen richting }\end{array}$ & $\begin{array}{c}\text { (3) } \\
\text { Universitair niveau }\end{array}$ & $\begin{array}{c}\text { (4) } \\
\text { Vaste baan }\end{array}$ & $\begin{array}{c}\text { (5) } \\
\text { Relatief hoog } \\
\text { inkomen }\end{array}$ \\
\hline Vrouw & 0.497 & 0.0330 & $-3.755^{*}$ & -2.786 & $-15.68^{* * *}$ \\
\hline Leeftijd & 0.0984 & 0.220 & $-0.373^{*}$ & 0.130 & 0.0378 \\
\hline Niet-NL nationaliteit & -0.888 & $6.972^{* *}$ & $4.834^{* *}$ & $8.512^{* * *}$ & -0.740 \\
\hline Gepromoveerd & 1.412 & $6.883^{* *}$ & $12.02^{* * *}$ & $-23.53^{* * *}$ & $-12.91^{* * *}$ \\
\hline \multicolumn{6}{|c|}{ Faculteit (SBE is referentiegroep) } \\
\hline FHS & -1.395 & 0.518 & -6.164 & -2.831 & $-42.45^{* * *}$ \\
\hline FHML & 0.849 & $6.979^{* *}$ & -1.079 & $-4.718^{*}$ & $-11.77^{* * *}$ \\
\hline FASOS & $4.049^{* *}$ & $-35.61^{* * *}$ & $-11.35^{* *}$ & -3.316 & $-49.06^{* * *}$ \\
\hline FPN & 1.110 & 3.290 & 3.923 & -3.416 & $-31.95^{* * *}$ \\
\hline $\mathrm{FdR}$ & 0.513 & 5.065 & 3.952 & 1.117 & $-14.44^{* * *}$ \\
\hline \multicolumn{6}{|c|}{ Meetjaar (2011 is referentiegroep) } \\
\hline 2012 & 0.253 & -0.441 & -4.383 & 2.139 & -5.506 \\
\hline 2013 & 0.460 & $-6.556^{* *}$ & -1.959 & -0.157 & $-8.426^{* *}$ \\
\hline 2014 & -0.307 & -0.564 & 0.512 & -0.151 & \\
\hline 2015 & 0.890 & 0.666 & -1.150 & -2.089 & $-17.63^{* * *}$ \\
\hline Constante & -2.267 & $58.24^{* * *}$ & $105.6^{* * *}$ & $48.60^{* * *}$ & $103.0^{* * *}$ \\
\hline Observaties & 1,856 & 1,579 & 1,572 & 1,533 & 1,008 \\
\hline R2 & 0.008 & 0.059 & 0.036 & 0.108 & 0.137 \\
\hline
\end{tabular}

Bron: UM scanner 2011-2015, geen data beschikbaar voor inkomen in 2014

Gecontroleerd voor bedrijfsgrootte in kolom 2-5

${ }^{* * *} p<0.01,{ }^{* *} p<0.05,{ }^{*} p<0.1$

In de analyses met betrekking tot de tevredenheid en carrièremogelijkheden binnen de huidige functie nemen we dezelfde achtergrondfactoren mee als in de vorige analyse. Echter kunnen de hiervoor behandelde kernindicatoren (vast dienstverband, loon et cetera) ook van invloed zijn op de baantevredenheid of op de ervaren carrièremogelijkheden. Vandaar dat we deze ook opnemen in de regressies. In Tabel 5.3 en 5.4 laten we zien in hoeverre de baantevredenheid en de ervaren carrièremogelijkheden respectievelijk vijf en tien jaar na afstuderen verklaard kunnen worden door de persoons-, opleidings- en baankenmerken (zoals geslacht, faculteit en lonen).

Als we de kernindicatoren voor 'employability' constant houden, dan blijkt de faculteit waar iemand afgestudeerd aan is niet van invloed op de baantevredenheid. Er blijkt ook slechts één persoonskenmerk gerelateerd te zijn aan baantevredenheid: Nederlandse UM-afgestudeerden blijken vaker positief te zijn over de huidige functie dan niet-Nederlanders. Met betrekking tot de kernindicatoren zien we dat afgestudeerden die een baan hebben gevonden binnen het eigen kerndomein het meest tevreden zijn. Dit blijkt uit de positieve significante coëfficiënten van het hebben van een baan in de gekozen richting en op universitair niveau. Echter worden deze factoren minder belangrijk voor de tevredenheid als we kijken naar de situatie tien jaar na afstuderen. Enkel een baan 
op universitair niveau lijkt nog samen te hangen met de tevredenheid met de huidige functie. Daarnaast is er wel een nieuwe factor die meespeelt voor de baantevredenheid van de afgestudeerden; afgestudeerden met een volle baan 10 jaar na afstuderen kennen een iets grotere tevredenheid.

TABEL 5.3 Regressie output relatie tussen subjectieve kernindicatoren en gegevens UM-afgestudeerden T+5, 2011-2015

\begin{tabular}{|l|c|c|} 
& $(1)$ & $(2)$ \\
\hline Vrouw & Tevreden met huidige functie & Carrièremogelijkheden huidige functie \\
\hline Leeftijd & 1.395 & -0.569 \\
\hline Niet-NL nationaliteit & -0.363 & $-1.070^{* * *}$ \\
\hline Gepromoveerd & $-6.723^{* *}$ & $-7.993^{* *}$ \\
\hline Faculteit (SBE is referentiegroep) & 5.466 & $12.61^{* * *}$ \\
\hline FHS & & -2.703 \\
\hline FHML & -2.224 & -6.403 \\
\hline FASoS & -0.596 & $-14.66^{* * *}$ \\
\hline FPN & -6.643 & $-13.33^{* *}$ \\
\hline FdR & -2.786 & $-8.167^{*}$ \\
\hline Gekozen richting & -7.097 & 0.0171 \\
\hline Universitair niveau & $0.0886^{* * *}$ & $0.188^{* * *}$ \\
\hline Vaste baan & $0.139^{* * *}$ & 0.0523 \\
\hline Relatief hoog inkomen & 0.0174 & $0.102^{* * *}$ \\
\hline Voltijdsbaan & 0.0444 & $0.0875^{* *}$ \\
\hline Meetjaar (2011 is referentiegroep) & 0.0385 & -4.484 \\
\hline 2012 & & -4.292 \\
\hline 2013 & -4.855 & $-9.832^{* *}$ \\
\hline 2015 & 0.388 & $88.33^{* * *}$ \\
\hline Constante & -5.427 & 1,233 \\
\hline Observaties & $76.59^{* * *}$ & 0.108 \\
\hline R2 & 1,234 & 0.047 \\
\hline Bron: & & \\
\hline
\end{tabular}

Bron: UM scanner 2011-2015, geen data beschikbaar voor baantevredenheid en carrièremogelijkheden in 2014.

Gecontroleerd voor bedrijfsgrootte

${ }^{* * *} p<0.01,{ }^{* *} p<0.05,{ }^{*} p<0.1$

Het oordeel onder UM-afgestudeerden over de carrièremogelijkheden binnen de huidige functie lijkt van meer persoonsfactoren afhankelijk. Zo zijn oudere afgestudeerden en afstudeerden van niet-Nederlandse afkomst vijf jaar na afstuderen minder positief over de carrièremogelijkheden binnen de huidige functie. Dit blijkt ook tien jaar na afstuderen nog steeds het geval te zijn. Gepromoveerden blijken gemiddeld een positiever beeld van de carrièremogelijkheden te hebben. Ook de faculteit waaraan men afgestudeerd is speelt een rol in de mate waarin men goede carrièremogelijkheden ervaart. Afgestudeerden van SBE zijn onder de afgestudeerden het meest positief. De meeste kernindicatoren hebben ook een positieve relatie met het oordeel 
onder UM-afgestudeerden over de carrièremogelijkheden binnen de huidige functie. Afgestudeerden met een voltijdsbaan, een baan op universitair niveau of een baan met een relatief hoog inkomen geven vaker aan goede carrièremogelijkheden te hebben. Dit geldt grotendeels zowel vijf jaar als tien jaar na afstuderen. De betere (gepercipieerde) carrièremogelijkheden onder gepromoveerden en jongeren zijn tien jaar na afstuderen echter verdwenen. Afgestudeerden van FPN zijn tien jaar na afstuderen wel nog steeds minder tevreden over de carrièremogelijkheden dan SBE alumni.

TABEL 5.4 Regressie output relatie tussen subjectieve kernindicatoren en gegevens UM-afgestudeerden T+5, 2011-2015

\begin{tabular}{|l|c|c|} 
& $(1)$ & $(2)$ \\
\hline Vrouw & Tevreden met huidige functie & Carrièremogelijkheden huidige functie \\
\hline Leeftijd & 1.392 & -0.0539 \\
\hline Niet-NL nationaliteit & 0.126 & $-1.010^{* * *}$ \\
\hline Gepromoveerd & 3.775 & $-12.27^{* * *}$ \\
\hline Faculteit (SBE is referentiegroep) & 4.899 & 3.321 \\
\hline FHS & & \\
\hline FHML & 4.190 & -5.939 \\
\hline FASOS & $7.108^{*}$ & -6.810 \\
\hline FPN & -1.763 & -6.034 \\
\hline FdR & 3.417 & $-15.49^{* *}$ \\
\hline Gekozen richting & 1.529 & $-8.702^{*}$ \\
\hline Universitair niveau & 0.0253 & 0.0510 \\
\hline Vaste baan & $0.160^{* * *}$ & $0.214^{* * *}$ \\
\hline Relatief hoog inkomen & 0.0465 & -0.00133 \\
\hline Voltijdsbaan & 0.0454 & $0.0800^{* *}$ \\
\hline Meetjaar (2011 is referentiegroep) & $0.0544^{*}$ & $0.125^{* * *}$ \\
\hline 2012 & & \\
\hline 2013 & -3.777 & 0.278 \\
\hline Co15 & -2.986 & 1.067 \\
\hline Constante & $-19.64^{* * *}$ & -6.327 \\
\hline Rbservaties & $45.62^{* * *}$ & $77.04^{* * *}$ \\
\hline Bron: & 968 & 965 \\
\hline
\end{tabular}

Bron: UM scanner 2011-2015, geen data beschikbaar voor baantevredenheid en carrièremogelijkheden in 2014.

Gecontroleerd voor bedrijfsgrootte

${ }^{* * *} p<0.01,{ }^{* *} p<0.05,{ }^{*} p<0.1$

\subsection{De rol van persoonsfactoren en opleidingen}

Door het combineren van de vijf meest recente cohorten kunnen ook uitspraken gedaan worden op het niveau van individuele masteropleidingen. ${ }^{13}$ De volgende analyses hebben betrekking op opleidingen die binnen de UM aangeboden werden in de periode

13 Deze analyses zijn alleen uitgevoerd voor de $T+5$ meting. 
2004/2005-2008/2009 (opleidingen met minder dan 20 respondenten zijn uitgezonderd van deze analyses). In totaal kunnen we in deze analyses 30 opleidingen onderscheiden. We nemen International Business als referentiegroep voor de opleidingen.

De rol van persoonskenmerken in het verklaren van de kernindicatoren van 'employability' blijft onveranderd nu we masteropleidingen in plaats van faculteiten (Tabel 5.1) opnemen in de analyses. Als we kijken naar de SBE-opleidingen dan zijn er geen verschillen waarneembaar in de diverse 'employability' indicatoren ten opzichte van de master International Business.

Met betrekking tot werkloosheid zijn er drie master opleidingen binnen FdGW en drie binnen rechten waar het werkloosheidspercentage significant hoger ligt dan onder de afgestudeerden van IB. Het gaat hier om de opleidingen health economics, policy and law, physical activity and health, public health, Nederlands recht, Nederlands strafrecht in Europa en globalisation and law. Daarnaast geldt ook voor analysing Europe en cultuur- en wetenschapsstudies een significant hoger werkloosheidspercentage.

De kans op het hebben van een baan in het vakgebied is (ten opzichte van de opleiding IB) significant lager voor alle FASoS masteropleidingen, met uitzondering van European public affairs. Ook afgestudeerden van de opleiding Nederlands strafrecht in Europa en physical activity and health hebben een grotere kans op een baan buiten het vakgebied. Daarentegen hebben afgestudeerden van de opleidingen mental health en geneeskunde juist een grotere kans op een baan binnen het vakgebied. De kans op het hebben van een baan op wo-niveau verschilt over het algemeen weinig tussen de masteropleidingen. Er zijn slechts een handvol opleidingen met een significant verschil ten opzichte van IB. Voorbeelden zijn de significant lagere kans op een baan op universitair niveau onder de afgestudeerden van physcial activity and health en algemene cultuurwetenschappen, en de significant grotere kans onder de afgestudeerden van fiscaal recht en geneeskunde.

De kans op een vaste baan is significant kleiner onder vrijwel alle opleidingen behorende bij FdGW vergeleken met IB. Dit geldt ook voor diverse opleidingen bij FASoS. De kans op een relatief hoog inkomen is, vergeleken met afgestudeerden van IB, ook bijna voor alle afgestudeerden aan andere faculteiten dan SBE, significant lager. De enige uitzonderingen zijn afgestudeerden van fiscaal recht, recht, arbeid en gezondheid, en globalisation and law. 
TABEL 5.5 Regressie output relatie tussen kernindicatoren en gegevens UM-afgestudeerden met de focus op master opleidingen $T+5,2011-2015$

\begin{tabular}{|c|c|c|c|c|c|}
\hline & $\begin{array}{c}\text { (1) } \\
\text { Werkloosheid }\end{array}$ & $\begin{array}{c}\text { (2) } \\
\text { Gekozen } \\
\text { richting }\end{array}$ & $\begin{array}{c}\text { (3) } \\
\text { Universitair } \\
\text { niveau }\end{array}$ & $\begin{array}{c}\text { (4) } \\
\text { Vaste baan }\end{array}$ & $\begin{array}{c}\text { (5) } \\
\text { Relatief hoog } \\
\text { inkomen }\end{array}$ \\
\hline Vrouw & -0.0220 & 1.333 & $-3.049^{*}$ & -2.303 & $-5.245^{*}$ \\
\hline Leeftijd & $0.226^{* *}$ & 0.271 & -0.0991 & $0.489^{* *}$ & $0.828^{* * *}$ \\
\hline Niet-NL nationaliteit & $2.033^{* *}$ & $7.055^{* * *}$ & $6.523^{* * *}$ & 2.985 & -1.311 \\
\hline Gepromoveerd & 1.637 & $13.31^{* * *}$ & $10.67^{* * *}$ & $-26.87^{* * *}$ & $-17.16^{* * *}$ \\
\hline \multicolumn{6}{|c|}{ Opleiding (International Business is referentiegroep) } \\
\hline Econometrie en operationele research & -2.606 & 1.468 & 5.113 & -1.752 & 15.20 \\
\hline Economics & -1.149 & 4.377 & -1.644 & -0.821 & -9.144 \\
\hline Fiscale Economie & -1.177 & 11.87 & 1.540 & 16.09 & -5.938 \\
\hline Bedrijfswetenschappen & -0.527 & -6.025 & -2.696 & 2.931 & -1.715 \\
\hline Finance & -1.183 & -4.841 & 5.094 & 12.45 & 18.85 \\
\hline Psychology & 1.896 & $-8.476^{*}$ & -0.0848 & $-30.59^{* * *}$ & $-35.37^{* * *}$ \\
\hline Public Policy and Human Development & 0.655 & -9.609 & 5.362 & $-19.52^{* *}$ & $-21.80^{*}$ \\
\hline Gezondheidswetenschappen & 1.954 & -10.05 & -9.817 & -10.67 & $-22.65^{*}$ \\
\hline Mental Health & -0.240 & $10.91^{* *}$ & -1.249 & $-12.01^{* *}$ & $-19.10^{* *}$ \\
\hline Health Economics, Policy and Law & $7.750^{* *}$ & -10.95 & -5.782 & -14.08 & $-33.96^{* * *}$ \\
\hline Physical Activity and Health & $6.078^{* *}$ & $-16.54^{* * *}$ & $-26.09^{* * *}$ & $-22.78^{* * *}$ & $-18.56^{*}$ \\
\hline Public Health & $5.334^{* *}$ & -6.600 & -3.892 & $-23.50^{* * *}$ & $-36.42^{* * *}$ \\
\hline Geneeskunde & -0.379 & $16.75^{* * *}$ & $12.09^{* * *}$ & $-47.93^{* * *}$ & $-32.32^{* * *}$ \\
\hline Algemene Gezondheidswetenschappen & 0.543 & -3.768 & $-10.85^{* *}$ & $-11.25^{* *}$ & $-25.09^{* * *}$ \\
\hline European Law School & -1.662 & -0.173 & 2.588 & -7.091 & $-37.86^{* * *}$ \\
\hline Nederlands Recht & $4.137^{* *}$ & -7.336 & 2.285 & -3.857 & $-20.83^{* * *}$ \\
\hline Fiscaal recht & -1.936 & 3.511 & $12.46^{* *}$ & -1.098 & -2.467 \\
\hline Nederlands Strafrecht in Europe & $9.013^{* *}$ & $-18.43^{* *}$ & -8.023 & -3.002 & $-44.82^{* * *}$ \\
\hline Recht, Arbeid en Gezondheid & -1.158 & 9.668 & $-31.10^{* * *}$ & 2.464 & 14.05 \\
\hline Globalisation and Law & $13.82^{* * *}$ & -15.95 & -12.60 & -5.035 & 9.513 \\
\hline European Studies & -0.482 & $-24.31^{* * *}$ & -0.253 & $-17.10^{* * *}$ & $-36.67^{* * *}$ \\
\hline European Public Affairs & 5.455 & 4.819 & 8.348 & $-23.08^{* *}$ & $-21.74^{*}$ \\
\hline Analysing Europe & $11.56^{* * *}$ & $-40.99^{* * *}$ & 3.214 & -11.17 & $-29.55^{* *}$ \\
\hline Algemene Cultuurwetenschappen & 5.577 & $-38.56^{* * *}$ & $-23.30^{* *}$ & -18.41 & $-62.93^{* * *}$ \\
\hline Cultuur- en Wetenschapsstudies & $12.17^{* * *}$ & $-42.89^{* * *}$ & 1.611 & $-18.42^{*}$ & $-23.30^{* *}$ \\
\hline Kunst- en Cultuurwetenschappen & 5.727 & $-33.13^{* * *}$ & -14.26 & $-26.22^{*}$ & $-34.76^{*}$ \\
\hline Mediacultuur & 5.087 & $-46.59 * * *$ & -11.02 & $-19.28^{*}$ & $-61.49^{* * *}$ \\
\hline Cultuurbeleid, -beheer en -behoud & -1.557 & $-17.68^{*}$ & -11.84 & -3.536 & $-42.95^{* * *}$ \\
\hline Cultures of Arts, Science and Technology & $6.628^{*}$ & $-24.30^{* * *}$ & $-18.90^{* *}$ & $-42.64^{* * *}$ & $-64.68^{* * *}$ \\
\hline \multicolumn{6}{|l|}{ Meetjaar (2011 is referentiegroep) } \\
\hline 2012 & -0.0382 & $-5.427^{*}$ & -0.249 & 4.159 & -5.502 \\
\hline 2013 & -1.001 & -0.716 & 4.077 & -1.400 & -5.096 \\
\hline 2014 & -0.726 & 1.287 & -0.232 & 2.475 & \\
\hline 2015 & 1.642 & -0.141 & -1.817 & $-17.07^{* * *}$ & $-16.33^{* * *}$ \\
\hline Constante & $-8.027^{* *}$ & $64.41^{* * *}$ & $89.62^{* * *}$ & $55.45^{* * *}$ & $73.44^{* * *}$ \\
\hline Observaties & 1,861 & 1,598 & 1,591 & 1,582 & 1,118 \\
\hline R2 & 0.043 & 0.129 & 0.105 & 0.234 & 0.174 \\
\hline
\end{tabular}

Bron: UM scanner 2011-2015, geen data beschikbaar voor inkomen in 2014

Gecontroleerd voor bedrijfsgrootte in kolom 2-5

${ }^{* * *} p<0.01,{ }^{* *} p<0.05,{ }^{*} p<0.1$ 
TABEL 5.6 Regressie output relatie tussen subjectieve indicatoren en gegevens UM-afgestudeerden met de focus op master opleidingen $T+5,2011-2015$

\begin{tabular}{|c|c|c|}
\hline & $\begin{array}{c}\text { (1) } \\
\text { Tevredenheid met huidige functie }\end{array}$ & $\begin{array}{l}\text { (2) } \\
\text { Carrièremogelijkheden huidige functie }\end{array}$ \\
\hline Vrouw & 0.400 & -0.721 \\
\hline Leeftijd & -0.108 & $-0.888^{* * *}$ \\
\hline Niet-NL nationaliteit & $-7.914^{* *}$ & $-7.449^{* *}$ \\
\hline Gepromoveerd & 4.275 & $10.72^{* *}$ \\
\hline \multicolumn{3}{|c|}{ Opleiding (International Business is referentiegroep) } \\
\hline Econometrie en operationele research & 18.95 & 13.89 \\
\hline Economics & -3.163 & -5.166 \\
\hline Fiscale Economie & 2.458 & 6.275 \\
\hline Bedrijfswetenschappen & 0.0105 & 1.147 \\
\hline Finance & -4.647 & 5.302 \\
\hline Psychology & -2.636 & $-17.36^{* *}$ \\
\hline Public Policy and Human Development & -12.56 & -9.005 \\
\hline Gezondheidswetenschappen & -6.567 & $-27.47^{* *}$ \\
\hline Mental Health & -0.0375 & -9.040 \\
\hline Health Economics, Policy and Law & $-22.81^{* *}$ & $-22.32^{*}$ \\
\hline Physical Activity and Health & -13.33 & $-31.44^{* * *}$ \\
\hline Public Health & -9.891 & $-19.86^{* *}$ \\
\hline Geneeskunde & 8.495 & 3.513 \\
\hline Algemene Gezondheidswetenschappen & 0.549 & -7.797 \\
\hline European Law School & -11.11 & -14.87 \\
\hline Nederlands Recht & -9.005 & $-12.26^{*}$ \\
\hline Fiscaal recht & 2.897 & 17.42 \\
\hline Nederlands Strafrecht in Europe & $-22.06^{*}$ & $-28.70^{* *}$ \\
\hline Recht, Arbeid en Gezondheid & -23.53 & 6.849 \\
\hline Globalisation and Law & -1.184 & -19.91 \\
\hline European Studies & -11.48 & $-18.02^{* *}$ \\
\hline European Public Affairs & -16.41 & $-29.46^{* *}$ \\
\hline Analysing Europe & 2.993 & -7.629 \\
\hline Algemene Cultuurwetenschappen & 15.84 & -5.172 \\
\hline Cultuur- en Wetenschapsstudies & -11.71 & $-20.38^{*}$ \\
\hline Kunst- en Cultuurwetenschappen & -14.45 & -11.38 \\
\hline Mediacultuur & -0.403 & -8.758 \\
\hline Cultuurbeleid, -beheer en -behoud & 3.758 & -7.208 \\
\hline Cultures of Arts, Science and Technology & -13.31 & $-30.23^{*}$ \\
\hline Gekozen richting & $0.0758^{* *}$ & -0.00916 \\
\hline Universitair niveau & $0.151^{* * *}$ & $0.196^{* * *}$ \\
\hline Vaste baan & 0.0283 & 0.0466 \\
\hline Relatief hoog inkomen & 0.0359 & $0.0878^{* * *}$ \\
\hline \multicolumn{3}{|l|}{ Meetjaar (2011 is referentiegroep) } \\
\hline 2012 & -3.931 & -5.488 \\
\hline 2013 & 3.461 & -2.894 \\
\hline 2015 & -6.499 & $-12.19^{* *}$ \\
\hline Constante & $70.38^{* * *}$ & $87.44^{* * *}$ \\
\hline Observaties & 1,097 & 1,096 \\
\hline R2 & 0.078 & 0.134 \\
\hline
\end{tabular}

Bron: UM scanner 2011-2015, geen data beschikbaar voor baantevredenheid en carrièremogelijkheden in 2014.

Gecontroleerd voor bedrijfsgrootte

*** $\mathrm{p}<0.01,{ }^{* *} \mathrm{p}<0.05,{ }^{*} \mathrm{p}<0.1$ 
Tabel 5.6 laat de resultaten zien van analyses waarin de baantevredenheid en carrièremogelijkheden worden afgezet tegen persoonskenmerken en de masteropleidingen. Op het eerste gezicht is het opvallend dat, ondanks de grote verschillen in kernindicatoren, de baantevredenheid niet zo verschillend is per opleiding. $\mathrm{Er}$ is slechts één masteropleiding waar de afgestudeerden significant minder tevreden zijn dan die van IB. Het betreft hier Health Economics, Policy and Law. De reden voor het ontbreken van meerdere significante verschillen tussen opleidingen is waarschijnlijk te wijten aan het meenemen van de controlevariabelen gekozen richting en universitair niveau. Met andere woorden, doordat we in de analyses rekening houden met het hebben van een baan op wo-niveau en het hebben van een baan in het vakgebied, lijkt het erop dat de opleidingen vergelijkbaar zijn in de mate waarin afgestudeerden tevreden zijn met hun baan vijf jaar geleden. Echter, omdat de kans op een baan op wo-niveau en op een baan in het vakgebied zo sterk gerelateerd zijn aan de verschillende opleidingen is dit niet helemaal het geval. De ontevredenheid loopt dan echter via de hogere kans op een buiten onder wo-niveau en een baan buiten het vakgebied. Uit Tabel 5.5 is op te maken welke master opleidingen significant slechter scoren op deze indicatoren vergeleken met IB.

Voor de carrièremogelijkheden geldt eenzelfde verhaal. Echter, ondanks het meenemen van de kernindicatoren blijven er toch nog een aantal significante verschillen tussen IB en andere opleidingen bestaan. Het betreft hier met name studies binnen FdGW en FASoS. Zeer bepalend voor het oordeel over de carrièremogelijkheden blijven de kernindicatoren baan op wo-niveau en het relatief hoge inkomen.

\subsection{De rol van persoonlijkheid, competenties en wo-instelling}

Voor de verschillende kernindicatoren achter 'employability' hebben we met de regressies onder UM-afgestudeerden een aantal factoren in kaart gebracht die gerelateerd zijn aan de mate van 'employability' van de afgestudeerden. Hoewel dit al tot veel interessante bevindingen leidt, was het aantal persoons- en opleidingskenmerken dat we mee konden nemen in de analyses beperkt. Daarnaast was het niet mogelijk om de UM afgestudeerden te vergelijken met afgestudeerden aan andere universiteiten en ontbraken indicatoren voor competenties. In deze paragraaf laten we aanvullende analyses zien die gebaseerd zijn op de landelijke wo T+5 meting uit 2015. Het betreft het afstudeercohort 2009/2010. De landelijke wo T+5 meting is een stuk uitgebreider dan de UM scanner en bevat daarom veel meer mogelijke determinanten. Allereerst nemen we nu een scala aan persoonlijkheidskenmerken zoals tijd- en risicovoorkeur en de Big ${ }^{14}$ eigenschappen mee. Literatuur heeft namelijk laten zien dat dit soort persoonlijkheidskenmerken gerelateerd zijn aan arbeidsmarktuitkomsten (bijv. Golsteyn, Grönqvist \& Lindahl, 2014; Lee \& Ohtake, 2012). Daarnaast kunnen we nu rekening houden met de opleidingsvarianten deeltijd/duaal en nemen we de totale werkervaring sinds afstuderen mee als ook of men kinderen heeft. Bovendien kunnen we de verschillende universiteiten nu onderscheiden.

14 De Big5 eigenschappen zijn conscientiousness, extraversion, agreeableness, neuroticism, openness to experience. 
Echter, als gevolg van gemaakte afspraken mogen we de andere universiteiten niet bij naam noemen en dus zijn deze in de tabel gerandomiseerd. De referentie universiteit is Maastricht University.

Een aantal van de correlaties die we eerder op UM-niveau in kaart hebben kunnen brengen blijken ook in de nationale context relevant te zijn. Onder afgestudeerden met een buitenlandse nationaliteit is er vijf jaar na afstuderen een (zwak significant) hogere werkloosheid en een grotere kans op een baan op universitair niveau of een vaste baan. Verder is er een hogere kans op een vaste baan of een baan met een relatief hoog inkomen wanneer de afgestudeerde ouder is. Voor promoveerde afgestudeerden is de kans groter dat ze een baan vinden op universitair niveau maar een kleine kans op een vaste baan. Opmerkelijk is dat we geen significante verschillen meer zien in de 'employability' indicatoren van mannen en vrouwen. De negatieve correlaties die we vonden tussen geslacht enerzijds en het vinden van een baan met een relatief hoog inkomen en een vaste baan blijken niet langer een rol te spelen in de verklarende analyse op nationaal niveau.

Naast de correlaties die enigszins overeen komen met wat we eerder al hadden gevonden komen er in Tabel 5.7 ook een aantal nieuwe determinanten van 'employability' naar voren. Zo heeft de totale werkervaring van een afgestudeerde na de studie een negatieve relatie met de kans opwerkloosheid, hoe langer de afgestudeerden heeft gewerkt na afstuderen hoe kleiner de kans om werkloos te zijn. Ook het vinden van een baan op wo-niveau (zwak significant), het hebben van een vaste baan en het hebben van een baan met een relatief hoog inkomen zijn positief gerelateerd aan werkervaring. De komst van kinderen is zwak negatief gecorreleerd een relatief hoog inkomen. Van de Big Five blijken "Extraversion" en "Agreeableness" significant gerelateerd te zijn aan 'employability'. Ook tijdsvoorkeur is gerelateerd aan een drietal indicatoren. Hoe hoger de bereidheid om te wachten om daar later profijt van te hebben, hoe kleiner de kans op een baan binnen het vakgebied (zwak significant), op een vaste baan en op een baan met een relatief hoog inkomen (zwak significant). Een verklaring hiervoor kan zijn dat afgestudeerden met een dergelijke tijdsvoorkeur banen accepteren als AIOS of in een tenure track/ postdoc posities die pas later in de carrière leiden tot vaste en goedbetaalde banen. We vinden geen relatie tussen risicovoorkeuren en de 'employability' indicatoren. Borghans, Fouarge en de Grip (2011) vonden wel een positieve relatie tussen risicovoorkeuren aan de ene kant en de bereidheid om binnen vijf jaar van baan te wisselen en de kans om een vergelijkbare baan te vinden indien men nu op zoek zou moeten naar een andere baan. Het is hierbij wel belangrijk om op te merken dat we hier niet alleen te maken hebben met andere indicatoren van 'employability' als ook met een andere groep respondenten. In de studie van Borghans e.a. (2011) was geen focus op recent universitair afgestudeerden maar van de gehele werkzame beroepsbevolking.

Met betrekking tot de competenties vinden we dat competenties zowel gerelateerd zijn aan een relatief kleine kans op een baan binnen het vakgebied (logisch redeneren en werken conform budget, planning) als aan een relatief hoge kans op een baan binnen 
het vakgebied (kennis van eigenvakgebied en toepassen kennis in de praktijk). We vinden een negatieve relatie tussen het vermogen om gebruik te maken van informatie en communicatietechnologieën en het hebben van een baan op wo-niveau. Het in staat zijn om anderen duidelijk te maken wat je bedoelt, is dan juist weer positief gerelateerd aan een baan op wo-niveau. Afgestudeerden die vijf jaar na afstuderen goed zijn in buitenlandse talen en in het leren van nieuwe dingen hebben minder vaak een vaste baan, terwijl afgestudeerden die conform budget en planning werken juist een hogere kans hebben op een vaste baan. Afgestudeerden die goed in staat zijn om vakkennis om te zetten in de praktijk hebben een hogere kans op een baan met een relatief hoog inkomen. Sommige van deze relaties zijn moeilijk te verklaren en dat kan ermee te maken hebben dat de competenties niet direct na afstuderen zijn gemeten maar vijf jaar later.

Met betrekking tot de instellingsdummies valt uit Tabel 5.7 op te maken dat er nauwelijks significante verschillen zijn tussen de 'employability' indicatoren van UM afgestudeerden en die van andere Nederlandse universiteiten. Er is één uitzondering. Er blijkt namelijk één universiteit te zijn waarvan de afgestudeerden een significant hogere kans hebben om vijf jaar na afstuderen een baan met een relatief hoog inkomen te hebben in vergelijking met afgestudeerden van de UM.

Met betrekking tot de HOOP-gebieden blijken er, gecontroleerd voor persoonsfactoren, persoonlijkheid en instelling, geen significante verschillen tussen werkloosheidskansen onder economie afgestudeerden en alle afgestudeerden van de andere HOOP-gebieden. Vergeleken met afgestudeerden van economie, hebben afgestudeerden van alle andere HOOP-gebieden een significant kleinere kans op een vaste baan. Met uitzondering van recht en openbare orde geldt dit ook voor de kans op een relatief hoog inkomen. De kans op een baan in het vakgebied of op wo-niveau is alleen voor afgestudeerden van de richting kunst, taal en cultuur significant lager dan voor afgestudeerden van de richting economie.

TABEL 5.7 Regressie output relatie tussen kernindicatoren en gegevens afgestudeerden van Nederlandse universiteiten, 2015

\begin{tabular}{|l|c|c|c|c|c|} 
& $\begin{array}{c}(1) \\
\text { Werkloosheid }\end{array}$ & $\begin{array}{c}(2) \\
\text { Gekozen } \\
\text { richting }\end{array}$ & $\begin{array}{c}(3) \\
\text { Universitair } \\
\text { niveau }\end{array}$ & $\begin{array}{c}(4) \\
\text { Vaste baan }\end{array}$ & $\begin{array}{c}\text { (5) } \\
\text { Relatief hoog } \\
\text { inkomen }\end{array}$ \\
\hline Vrouw & -1.836 & -2.337 & 0.0149 & $-7.228^{*}$ & -5.873 \\
\hline Leeftijd & 0.179 & 0.0691 & 0.149 & $0.920^{* *}$ & $0.905^{* *}$ \\
\hline Niet-NL nationaliteit & $3.522^{*}$ & $8.218^{*}$ & $11.98^{* * *}$ & 5.577 & 0.850 \\
\hline Gepromoveerd & -1.931 & 4.946 & $13.45^{* * *}$ & $-12.37^{* *}$ & 7.252 \\
\hline Deeltijd & 0.572 & -1.988 & 0.917 & 8.068 & -2.273 \\
\hline Duaal & -2.836 & 26.30 & 21.92 & 12.29 & 53.81 \\
\hline Totale werkervaring & $-0.0584^{* *}$ & 0.0580 & 0.0986 & $0.318^{* * *}$ & $0.252^{* *}$ \\
\hline Kind & -0.489 & -1.704 & -1.731 & -1.215 & $-3.187^{*}$ \\
\hline Conscientiousness & 0.143 & 0.132 & 0.543 & $-4.824^{* *}$ & -2.164 \\
\hline
\end{tabular}




\begin{tabular}{|c|c|c|c|c|c|}
\hline & $\begin{array}{c}\text { (1) } \\
\text { Werkloosheid }\end{array}$ & $\begin{array}{c}\text { (2) } \\
\text { Gekozen } \\
\text { richting }\end{array}$ & $\begin{array}{c}\text { (3) } \\
\text { Universitair } \\
\text { niveau }\end{array}$ & $\begin{array}{c}\text { (4) } \\
\text { Vaste baan }\end{array}$ & $\begin{array}{c}\text { (5) } \\
\text { Relatief hoog } \\
\text { inkomen }\end{array}$ \\
\hline Extraversion & 0.0437 & -0.510 & $-5.657^{* * *}$ & 4.354 & -0.604 \\
\hline Agreeableness & 0.879 & $3.697^{* *}$ & 1.731 & -0.206 & 0.731 \\
\hline Neuroticism & 0.0582 & 1.217 & 0.455 & -1.666 & 2.461 \\
\hline Openness to experience & 0.303 & -0.393 & 2.472 & 1.451 & 1.483 \\
\hline Tijdspreferentie & 1.021 & $-3.674^{*}$ & 1.013 & $-5.745^{* *}$ & $-5.185^{*}$ \\
\hline Risico & -1.210 & -2.639 & 0.471 & 2.391 & -0.166 \\
\hline Goede doelen & 0.705 & 2.213 & 0.0191 & -0.433 & -0.321 \\
\hline Kennis eigen vakgebied & & $7.463^{* * *}$ & 3.282 & -2.873 & 1.439 \\
\hline Kennis andere vakgebieden & & $-3.939^{*}$ & -2.455 & 3.068 & 2.969 \\
\hline Vermogen gebruiken inf./comm.technologien & & -1.651 & $-5.438^{* * *}$ & 2.591 & -1.286 \\
\hline Vermogen communiceren buitenlandse talen & & $2.585^{*}$ & 1.627 & $-7.055^{* * *}$ & $-4.029^{*}$ \\
\hline Vermogen logisch redeneren & & $-5.832^{* *}$ & 1.374 & -1.034 & -1.380 \\
\hline Vermogen werken conform budget,planning & & $-4.681^{* * *}$ & -2.331 & $6.692^{* * *}$ & -3.452 \\
\hline $\begin{array}{l}\text { Vermogen bedenken nieuwe } \\
\text { ideeen,oplossingen }\end{array}$ & & -0.545 & $-3.895^{*}$ & 0.195 & -3.371 \\
\hline Vermogen leren nieuwe dingen & & -1.472 & -2.132 & $-7.490^{* *}$ & -0.973 \\
\hline Vermogen productief samenwerken & & -2.148 & 3.451 & -1.027 & 3.441 \\
\hline Vermogen aanspreken capaciteiten anderen & & 0.824 & -0.560 & 2.260 & 1.162 \\
\hline Vermogen verbanden leggen tussen zaken & & 2.037 & -0.0155 & 4.323 & 2.269 \\
\hline Vermogen uw bedoelingen duidelijk maken & & 0.273 & $6.420^{* * *}$ & 4.162 & -1.185 \\
\hline $\begin{array}{l}\text { Vermogen zelfstandig werkzaamheden } \\
\text { uitvoeren }\end{array}$ & & -2.467 & -3.538 & 5.371 & -0.199 \\
\hline Vermogen toepassen vakkennis in prakijk & & $6.871^{* * *}$ & 2.852 & 3.913 & $6.232^{* *}$ \\
\hline \multicolumn{6}{|l|}{ Universiteit (UM is referentiegroep) } \\
\hline Universiteit a & -0.903 & 1.392 & 2.995 & 2.411 & $13.59^{* *}$ \\
\hline Universiteit b & 0.733 & 6.363 & -0.137 & 6.705 & 2.691 \\
\hline Universiteit c & -1.314 & 1.470 & -3.691 & 0.448 & -2.681 \\
\hline Universiteit d & 0.382 & 5.122 & -1.725 & 8.314 & 3.281 \\
\hline \multicolumn{6}{|l|}{ H0OP-gebied (economie is referentiegroep) } \\
\hline Gezondheidszorg & 3.875 & 4.637 & 5.295 & $-37.45^{* * *}$ & $-17.01^{* *}$ \\
\hline Gedrag en Maatschappij & 2.210 & -4.315 & 2.659 & $-22.87^{* * *}$ & $-19.05^{* * *}$ \\
\hline Kunst, taal en cultuur & 4.086 & $-27.00^{* * *}$ & $-10.40^{*}$ & $-20.33^{* * *}$ & $-27.42^{* * *}$ \\
\hline Recht en openbare orde & 2.132 & -1.427 & 6.428 & $-18.20^{* *}$ & $-14.47^{*}$ \\
\hline Natuurwetenschappen & 4.456 & -9.335 & -0.653 & $-32.57^{* * *}$ & $-28.86^{* * *}$ \\
\hline Constante & -8.375 & $82.43^{* * *}$ & $64.21 * * *$ & 5.469 & 33.27 \\
\hline Observaties & 871 & 739 & 740 & 690 & 675 \\
\hline Observaties UM & 179 & 136 & 136 & 136 & 136 \\
\hline R-squared & 0.029 & 0.155 & 0.129 & 0.274 & 0.149 \\
\hline
\end{tabular}

Bron: wo T+5, 2015

Gecontroleerd voor bedrijfsgrootte in kolom 2-5

${ }^{* * *} p<0.01,{ }^{* *} p<0.05,{ }^{*} p<0.1$ 
TABEL 5.8 Regressie output relatie tussen subjectieve indicatoren en gegevens afgestudeerden van Nederlandse universiteiten, 2015

\begin{tabular}{|c|c|c|}
\hline & $\begin{array}{l}\text { (1) } \\
\text { Tevredenheid met } \\
\text { huidige functie }\end{array}$ & $\begin{array}{l}\text { (2) } \\
\text { Carrièremogelijkheden } \\
\text { huidige functie }\end{array}$ \\
\hline Vrouw & -0.867 & -4.011 \\
\hline Leeftijd & -0.145 & -0.766 \\
\hline Niet-NL nationaliteit & $-13.93^{* *}$ & $-11.96^{*}$ \\
\hline Gepromoveerd & 0.282 & 2.351 \\
\hline Deeltijd & -10.19 & 1.428 \\
\hline Duaal & $-72.43^{* *}$ & 1.943 \\
\hline Totale werkervaring & 0.144 & $-0.196^{*}$ \\
\hline Kind & 1.207 & 0.285 \\
\hline Conscientiousness & 2.463 & -0.275 \\
\hline Extraversion & $5.763^{* *}$ & 3.015 \\
\hline Agreeableness & $4.295^{* *}$ & 2.162 \\
\hline Neuroticism & -0.420 & 2.250 \\
\hline Openness to experience & 3.695 & -0.0432 \\
\hline Tijdspreferentie & -4.071 & 1.272 \\
\hline Risico & -2.000 & $5.543^{* *}$ \\
\hline Goede doelen & $3.814^{*}$ & 1.977 \\
\hline Kennis eigen vakgebied & -2.667 & -5.092 \\
\hline Kennis andere vakgebieden & 0.236 & 0.920 \\
\hline Vermogen gebruiken inf./comm.technologien & -0.0338 & -0.829 \\
\hline Vermogen communiceren buitenlandse talen & $-4.789^{* *}$ & 1.174 \\
\hline Vermogen logisch redeneren & $6.644^{*}$ & 0.237 \\
\hline Vermogen werken conform budget,planning & -3.277 & 0.110 \\
\hline Vermogen bedenken nieuwe ideeen,oplossingen & 1.490 & 1.040 \\
\hline Vermogen leren nieuwe dingen & -0.756 & 0.564 \\
\hline Vermogen productief samenwerken & 4.548 & 4.606 \\
\hline Vermogen aanspreken capaciteiten anderen & -3.572 & -1.428 \\
\hline Vermogen verbanden leggen tussen zaken & 1.117 & 2.217 \\
\hline Vermogen uw bedoelingen duidelijk maken & -1.245 & -3.328 \\
\hline Vermogen zelfstandig werkzaamheden uitvoeren & -0.948 & $-8.933^{* *}$ \\
\hline Vermogen toepassen vakkennis in prakijk & 2.660 & $5.446^{*}$ \\
\hline \multicolumn{3}{|l|}{ Universiteit (UM is referentiegroep) } \\
\hline Universiteit a & -4.731 & 2.467 \\
\hline Universiteit b & 1.822 & 6.454 \\
\hline Universiteit c & -0.456 & 4.737 \\
\hline Universiteit d & -2.997 & 3.117 \\
\hline Gekozen richting & $-0.139^{* *}$ & $-0.200^{* * *}$ \\
\hline Universitair niveau & $0.183^{* * *}$ & $0.129^{* *}$ \\
\hline Vaste baan & 0.0230 & 0.0236 \\
\hline Relatief hoog inkomen & 0.0457 & $0.0918^{* *}$ \\
\hline \multicolumn{3}{|l|}{ H0OP-gebied (economie is referentiegroep) } \\
\hline Gezondheidszorg & 1.836 & -1.359 \\
\hline
\end{tabular}




\begin{tabular}{|l|c|c|} 
& $\begin{array}{c}(1) \\
\text { Tevredenheid met } \\
\text { huidige functie }\end{array}$ & $\begin{array}{c}\text { (2) } \\
\text { Carrièremogelijkheden } \\
\text { huidige functie }\end{array}$ \\
\hline Gedrag en Maatschappij & -3.660 & -6.656 \\
\hline Kunst, taal en cultuur & -6.004 & -13.96 \\
\hline Recht en openbare orde & 8.582 & $16.08^{*}$ \\
\hline Natuurwetenschappen & 5.533 & -5.561 \\
\hline Constante & -3.071 & $62.45^{*}$ \\
\hline Observaties & 627 & 627 \\
\hline Observaties UM & 111 & 111 \\
\hline R-squared & 0.154 & 0.121 \\
\hline
\end{tabular}

Bron: wo T+5, 2015

Gecontroleerd voor bedrijfsgrootte

${ }^{* * *} \mathrm{p}<0.01,{ }^{* *} \mathrm{p}<0.05,{ }^{*} \mathrm{p}<0.1$

Ook voor de tevredenheid over en de carrièremogelijkheden binnen de huidige functie komen de resultaten van de landelijke analyse (Tabel 5.8) grotendeels overeen met de resultaten onder UM-afgestudeerden. Buitenlandse afgestudeerden zijn minder tevreden over de huidige functie en zijn tevens minder positief over de carrièremogelijkheden binnen deze functie. Daarbij verslechtert het oordeel over de carrièremogelijkheden ook hoe ouder de afgestudeerde is. In tegenstelling tot de resultaten van de UM vinden we echter geen significante relatie meer tussen promoveren en het oordeel over de carrièremogelijkheden. Met betrekking tot de kernindicatoren zien we dat een baan op universitair niveau bijdraagt aan een hogere tevredenheid en aan een positiever oordeel over de carrièremogelijkheden. Daarnaast is het hebben van een relatief hoog inkomen ook positief gerelateerd aan carrièremogelijkheden. Echter vinden we voor de landelijke steekproef dat het werken in de gekozen richting juist negatief gerelateerd is zowel aan baantevredenheid en het oordeel van de carrièremogelijkheden. Deze bevindingen vinden we niet in Tabellen 5.3 en 5.4 waarin we ons alleen richten op de UM.

Tabel 5.8 laat ook nog een aantal nieuwe determinanten van baantevredenheid en carrièremogelijkheden zien. Afgestudeerden die hun opleiding aan de UM duaal hebben gevolg zijn over het algemeen minder tevreden met hun huidige functie. Ook blijkt dat hoe meer werkervaring de afgestudeerde heeft sinds het verlaten van de opleiding, hoe minder positief het oordeel is over de eigen carrièremogelijkheden binnen de huidige functie. Hoewel deze relatie zwak significant is, is dit best te verklaren. Hoe verder men is in de loopbaan, hoe minder mogelijkheden men heeft om hoger op te komen, simpelweg omdat men al relatief hoog op de ladder staat. Afgestudeerden met een hogere bereidheid om risico te nemen zijn juist positiever als het gaat over carrièremogelijkheden. Drie aspecten van de Big Five dragen bij aan een hogere tevredenheid onder afgestudeerden. "Extraversion", "Agreeableness" en "Openness to experience" zijn positief gecorreleerd met de tevredenheid met de huidige functie. Er blijken geen significante verschillen tussen de Nederlandse universiteiten te zijn als het gaat om baantevredenheid en goede carrièreperspectieven vijf jaar na afstuderen (gecontroleerd voor 
de kernindicatoren voor 'employability'). Ook zijn er nauwelijks significante verschillen tussen de afgestudeerden van verschillende HOOP-gebieden. Er zijn alleen zwak significante verschillen gevonden tussen het HOOP-gebied economie aan de ene kant en recht en openbare orde en natuurwetenschappen aan de andere kant. Deze beide HOOP-gebieden scoren zwak significant hoger op baantevredenheid dan economie.

Competenties blijken niet zo'n grote rol te spelen in het verklaren van baantevredenheid en carrièremogelijkheden. Voor beide indicatoren vinden we slechts één competentie die significant gerelateerd is. Baantevredenheid is lager onder afgestudeerden die goed in staat zijn in buitenlandse talen te communiceren. Carrièremogelijkheden blijken juist minder goed te zijn als men in staat is zelfstandig te werken. 


\section{6 \\ CONCLUSIES EN DISCUSSIE}

\subsection{Conclusies}

In dit hoofdstuk kijken we terug op de belangrijkste bevindingen uit voorgaande hoofdstukken. Het doel van de voorliggende studie was om de 'employability' van UM afgestudeerden in kaart te brengen en te verklaren. Om hier inzicht in te geven, zijn in de voorgaande hoofdstukken respectievelijk besproken: samenvatting van de relevante literatuur (Hoofdstuk 2), onderzoeksopzet (Hoofdstuk 3), 'employability' UM afgestudeerden in kaart gebracht (Hoofdstuk 4) en 'employability' UM afgestudeerden verklaard (Hoofdstuk 5). We komen in dit conclusiehoofdstuk terug op de onderzoeksvragen zoals deze geformuleerd zijn in Hoofdstuk 1.

\subsubsection{Belangrijkste conclusies uit de literatuur}

Er bestaan talloze definities van het concept 'employability' die meestal op elkaar lijken, maar vaak nét een iets andere insteek hebben. Wat ze met elkaar gemeen hebben, is dat 'employability' in ieder geval altijd iets te maken heeft met de arbeidsmarkt en werk. Ruwweg zijn de definities van'employability'te ordenen zijn op een schaal van'zeer individualistisch' tot 'zeer contextueel' georiënteerd.

Als we uitgaan van deze gangbare 'tussenvorm', namelijk dat de 'employability' van studenten/afgestudeerden zowel wordt bepaald door individuele eigenschappen alsook contextuele kenmerken, kunnen we ruwweg drie typen factoren onderscheiden die een rol spelen bij 'employability'. Individuele factoren, opleidings- en instellingsspecifieke factoren en arbeidsmarktfactoren.

Ruwweg zijn er twee typen indicatoren te onderscheiden om 'employability' te meten, objectieve indicatoren en subjectieve indicatoren. Bij de objectieve indicatoren gaat het om 'harde' arbeidsmarktuitkomsten. Deze indicatoren hebben te maken met het al dan niet vinden van werk, en indien men werk heeft met de arbeidsvoorwaarden en de functie-inhoudelijke aspecten. Bij 'subjectieve indicatoren' ligt de nadruk vooral op het beoordelen van persoonlijke competenties die nuttig geacht worden op de arbeidsmarkt, vaak ook wel 'employability skills' genoemd. Het gaat dan bijvoorbeeld om 'scores' op karakteristieken zoals leergierigheid of flexibiliteit, maar ook om meer concrete competenties zoals teamwork, communicatie en dergelijke. Daarnaast zijn er nog subjectieve indicatoren die wèl een directe relatie leggen met de baan en dus met 
de arbeidsmarktsituatie. Voorbeelden zijn de mate waarin de huidige baan aansluit op de competenties van personen en baantevredenheid.

Hoewel het hoger onderwijs door de loop van de jaren steeds meer aandacht is gaan schenken aan het ontwikkelen van 'employability' skills van studenten is er geen sterke empirische onderbouwing gevonden dat de 'employability' van afgestudeerden afkomstig van opleidingen met een sterke aandacht voor die competenties kansrijker zijn op de arbeidsmarkt. Hierbij moet wel rekening gehouden worden dat de studies zich alleen hebben gericht op de kortetermijneffecten. Waar wel goede aanwijzingen voor zijn, is de bijdrage van praktijkrelevantie in het onderwijs. Zo hebben studenten met een beroepsstage bijvoorbeeld een grotere kans op werk. Verder zijn er aanwijzingen dat opleidingen waarin het onderwijs samen met het bedrijfsleven wordt inrichten, betere perspectieven bieden voor hun studenten.

Samengevat kan men stellen dat de 'employability' literatuur vaak theoretisch van aard is, waardoor uitspraken over 'effectiviteit' of 'nut' moeilijk te doen zijn. Het lijkt dan ook zinvol om het fenomeen 'employability' in de toekomst meer vanuit een empirische bril te bezien. De voorliggende studie is daar een mooi voorbeeld van.

\subsection{2 'Employability' van UM afgestudeerden in 2015}

In deze studie is 'employability' gemeteen op basis van zeven indicatoren: werkloosheid, baan op universitair niveau, baan binnen vakgebied, vaste baan, relatief hoog inkomen, tevredenheid huidige funcie en carrieremogelijkheden huidige functie. Het is gegeven de data mogelijk om de volgende vijf faculteiten te onderscheiden: SBE, FHML, FASoS, FPN en FdR. Er is niet één faculteit die op alle zeven 'employability' indicatoren het hoogste scoort. Toch springen er twee faculteiten uit die het op de meeste gebieden relatief goed doen. Zo scoort SBE het beste op de kans op werk, op een vaste baan, op een baan met een relatief hoog inkomen en op geschatte carrièremogelijkheden. Wat betreft baantevredenheid en een baan op wo-niveau scoren ze ook in de top. FdR staat vergeleken met andere faculteiten ook ver bovenaan met betrekking tot werkloosheid, wo-niveau, vaste baan en relatief hoog inkomen. Daarnaast scoren ze gemiddeld op een baan binnen het vakgebied en op baantevredenheid en carrièremogelijkheden. Het is niet eenvoudig binnen deze faculteiten masteropleidingen aan te wijzen die duidelijk beter scoren dan andere. Dit hangt enorm af van de indicator. Zo doet de specialisatie finance van IB het ten opzichte van de andere SBE masters erg goed op zes van de zeven indicatoren, maar hebben afgestudeerden binnen finance wel de laagste kans op een baan binnen het vakgebied. Het is vervolgens aan ieder individu an sich om te bepalen welke indicatoren het belangrijkste zijn. Zo doet binnen FdR de European Law School het relatief goed met betrekking tot werkloosheid, werken in het vakgebied en werken op wo-niveau. Echter, de kans op een vaste baan of een baan met een relatief hoog inkomen zijn relatief laag. Ook zijn afgestudeerden van deze master relatief minder vaak tevreden met hun huidige baan en met de carrieremogelijkheden. De master globalisation and law is een master die het in vergelijking tot andere masters binnen FdR relatief slecht doet op de hier beschreven indicatoren van 'employability'. 
Afgestudeerden van FHML scoren met betrekking tot sommige 'employability' indicatoren relatief hoog, en voor andere juist weer relatief laag. Ze scoren het hoogste op baantevredenheid en werken ook relatief vaak in hun vakgebied (plaats 2) en ze zijn relatief vaak positief over hun carrièremogelijkheden (plaats 2). Echter, het werkloosheidspercentage is met $5,2 \%$ wel relatief hoog en ook is de kans op een baan op wo-niveau als ook de kans op een baan met een relatief hoog salaris juist weer laag vergeleken met andere faculteiten. De lage kans op een vaste baan is te wijten aan de vervolgopleidingen binnen FdG en zegt daarmee niet echt iets over 'employability'. De master physical activity and health scoort over het algemeen laag vergeleken met andere masters binnen FHML.

Afgestudeerden van FPN hebben de hoogste kans op een baan op wo-niveau en op een baan binnen het vakgebied. Echter, de kans op een vaste baan is relatief laag en dit geldt ook voor baantevredenheid en carrièremogelijkheden (plaats 4). Met betrekking tot werkloosheid en een relatief hoog inkomen zitten ze precies in het midden vergeleken met andere faculteiten.

Bij de afgestudeerden van FASoS is er duidelijk nog ruimte tot verbetering met betrekking tot de 'employability' indicatoren zoals vastgelegd in deze studie. De kans op werkloosheid, op een baan op wo-niveau, op een baan binnen het vakgebied, op een baan met een relatief hoog inkomen, op een baan waarmee ze tevreden zijn en op een baan met goede carrièremogelijkheden scoren ze het laagste vergeleken met de andere faculteiten. Echter, ook voor deze groep afgestudeerden geldt dat slechts $6,7 \%$ vijf jaar na afstuderen werkloos is. Onder de werkenden geldt dat meer dan drie kwart een baan op wo-niveau heeft. Toch zijn de vooruitzichten voor FASoS afgestudeerden, zeker vergeleken met afgestudeerden van andere faculteiten, niet gunstig.

\subsubsection{Ontwikkeling van 'employability' van UM afgestudeerden}

Over het algemeen geldt dat de 'employability' indicatoren van UM afgestudeerden relatief stabiel zijn. Uiteraard is de kans op werkloosheid gerelateerd aan de conjunctuur en was er in 2010 een piek in de werkloosheid. De kans op een baan op wo-niveau is sinds 2001 gestaag gestegen. Over de gehele UM ligt het percentage afgestudeerden dat werkzaam is op wo-niveau in 2015 ruim 20\%-punt hoger dan in 2001. De kans op een baan in het vakgebied is vrij stabiel over de laatste 15 jaar. Ongeveer $80 \%$ van alle UM afgestudeerden heeft vijf jaar na afstuderen een baan in het vakgebied. De kans op een vaste baan is de afgelopen 15 jaar behoorlijk gedaald. Dit heeft alles te maken met de flexibilisering van de arbeidsmarkt en is dan ook niet specifiek voor UM afgestudeerden. De kans op een baan met een relatief hoog inkomen is de afgelopen 15 jaar gedaald. Hoewel deze kans tussen 2005 en 2009 gestegen is, daalt deze sindsdien. Een dergelijke stijging wordt ook voor andere opleidingsniveaus waargenomen (ROA 2016b). De tevredenheid met de huidige functie is redelijk stabiel over de afgelopen 15 jaar, hoewel in 2012 en 2015 voor het eerst sinds 2001 minder dan drie kwart van de UM afgestudeerden 
tevreden is met de baan vijf jaar na afstuderen. Ook met betrekking tot het percentage afgestudeerden dat goede carrièremogelijkheden percipieert is er de laatste jaren, sinds 2011, een lichte afname te zien (van 70 naar 60\%).

Het is bovendien gebleken dat de trend op UM niveau niet hetzelfde verloop heeft als de onderliggende trends per faculteit. Hoewel voor FHML en in iets mindere mate voor SBE over het algemeen geldt dat de 'employability' indicatoren vrij stabiel zijn over de tijd, zijn de meeste 'employability' indicatoren erg veranderlijk over de tijd voor FdR.

\subsection{4 'Employability' van UM afgestudeerden vergeleken met andere universiteiten}

De vergelijking tussen UM afgestudeerden en afgestudeerden van andere universiteiten is het beste te maken aan de hand van de HOOP-gebieden. ${ }^{15}$ Over het algemeen zijn de verschillen klein. Toch zijn er een paar interessante verschillen: Het percentage afgestudeerden dat een baan op wo-niveau heeft is hoger onder UM afgestudeerden in de richtingen economie en gedrag \& maatschappij dan onder afgestudeerden van andere Nederlandse universiteiten samengenomen. Met betrekking tot het hebben van een baan in het vakgebied zijn er geen verschillen te vinden tussen UM afgestudeerden en afgestudeerden van andere universiteiten. De kansen op een vaste baan zijn binnen de UM significant lager dan gemiddeld onder afgestudeerden van andere Nederlande universiteiten binnen de HOOP-gebieden gedrag en maatschappij en recht en openbare orde. Dit zou te maken kunnen hebben met het hoge percentage afgestudeerden dat niet afkomstig is uit Nederland en een baan heeft in het buitenland waar andere regelgeving is met betrekking tot vaste banen. De kans op een baan met een relatief hoog inkomen is alleen binnen het HOOP-gebied gezondheidszorg significant anders onder UM afgestudeerden en afgestudeerden van andere Nederlandse universiteiten samengenomen. UM afgestudeerden op het gebied van gezondheidszorg hebben minder vaak een relatief hoog inkomen vergeleken met afgestudeerden van andere Nederlandse universiteiten. De baantevredenheid lijkt niet echt verschillend te zijn onder UM afgestudeerden en afgestudeerden bij andere universiteiten, met uitzondering van het vakgebied gedrag \& maatschappij. Hier scoren UM afgestudeerden relatief gezien minder hoog. Met betrekking tot de carrièremogelijkheden vinden we geen significante verschillen tussen UM afgestudeerden en afgestudeerden van andere universiteiten tesamen.

\subsection{5 'Employability' van UM afgestudeerden verklaard}

Uit de analyses komen een aantal determinanten van de 'employability' indicatoren naar voren. Allereerst hebben vrouwen een kleinere kans op een baan op universitair niveau en op een baan een relatief inkomen. Dit laatste geldt 10 jaar na afstuderen nog sterker dan vijf jaar na afstuderen. Afgestudeerden die niet uit Nederland komen zijn over het algemeen beter 'employable'. Ze hebben vaker een baan op wo-niveau en een baan in het vakgebied. Tien jaar na afstuderen hebben ze bovendien vaker een vaste baan. Dit kan alles te maken hebben met selectie-effecten: de betere buitenlandse studenten

15 Het is belangrijk hier op te merken dat er informatie is over een achttal universiteiten. Niet alle universiteiten hebben meegedaan aan de nationale T+5 meting in 2015. 
komen naar de UM of met het feit dat zij vaak een andere arbeidsmarkt bedienen dan de Nederlandse. Niet-Nederlanders blijken wel een significant kleinere kans te hebben om tevreden te zijn met hun baan vijf jaar na afstuderen en om hun carrièremogelijkheden als goed te definiëren. Gepromoveerde academici hebben weliswaar vaker een baan op wo-niveau en binnen hun richting, maar hebben minder vaak een vaste baan en minder vaak een baan met een relatief hoog inkomen. Ze hebben daarentegen wel een grotere kans op goede carrièremogelijkheden. Of afgestudeerden tevreden zijn met hun huidige functie en of zij goede carrièremogelijkheden zien binnen hun huidige functie blijkt vooral ook te maken te hebben met de objectieve maatstaven van 'employability'. Als men binnen het vakgebied werkt en een baan op wo-niveau heeft is men significant tevredener. Carrièremogelijkheden blijken vooral gerelateerd te zijn aan het vereiste opleidingsniveau en het inkomen. Daarnaast blijken carrièremogelijkheden beter voor afgestudeerden met een voltijd- versus een deeltijdbaan. De verschillen per faculteit en per master opleiding zoals beschreven in 6.3 komen over het algemeen in de verklarende analyses ook terug.

In een laatste set analyses hebben we voor afgestudeerden van een zevental universiteiten nog naar andere mogelijke determinanten gekeken. Een viertal persoonlijkheidskenmerken spelen een rol voor 'employability'. Allereerst hebben extroverte afgestudeerden een kleinere kans op een baan op wo-niveau én zijn ze vaker tevreden met hun huidige baan. Afgestudeerden die meer waarde hechten aan morgen dan aan vandaag hebben juist minder vaak een vaste baan en vaker een lager inkomen. Bovendien vinden we dat afgestudeerden die service gericht zijn, vaker tevreden zijn met hun huidige functie. Als laatste vinden we dat afgestudeerden die relatief bereid zijn om risico's te nemen vaker aangeven goede carrièremogelijkheden te zien binnen hun huidige functie.

\subsection{Discussie}

Er zijn relatief weinig empirische studies gericht op (het verhogen van) de'employability' van wo-afgestudeerden. In deze rapportage is de'employability'van UM afgestudeerden in kaart gebracht aan de hand van een zeven indicatoren en kan daarmee fungeren als een nulmeting. De UM wil namelijk een aantal activiteiten ontwikkelen of meer onder de aandacht brengen zodat studenten allereerst gefaciliteerd worden in hun academische en persoonlijke ontwikkeling en zich daarnaast bewuster worden van hun employability (Bastiaens \& Muijsers 2016). Door zowel studenten als afgestudeerden in de komende jaren te bevragen kan inzicht verkregen worden in de mate waarin deze activiteiten daadwerkelijk een bijdrage leveren aan hun academische en persoonlijke ontwikkeling en aan de mate van bewustzijn op het gebied van employability. 
In deze context is het belangrijk op te merken dat 'employability' geen eenduidige definitie kent. Veelal gaat het er echter om dat men in staat is om een baan te krijgen, maar ook om productiever te worden en in staat te zijn om van baan te veranderen en zich zowel binnen als buiten een specifieke baan aan te kunnen passen aan nieuwe (technologische) ontwikkelingen. Hiertoe wordt vanuit de theorie verondersteld dat men bepaalde competenties nodig heeft, maar ook dat de arbeidsmarktomstandigheden toereikend zijn. De mate waarin het onderwijs een rol kan spelen in het verkrijgen van de benodigde 'employability' competenties is nog niet veelvuldig onderzocht. Door het 'employability' beleid van de UM zorgvuldig te evalueren kunnen daardoor niet alleen haar eigen studenten profiteren maar ook die van andere universiteiten. Goed voorbeeld doet immers volgen.

Hiertoe is het belangrijk dat afgestudeerden zelf gevraagd wordt wat zij het meest belangrijk vinden binnen 'employability'. Is dat het hebben van een baan binnen hun vakgebied of vinden zij het vooral belangrijk dat ze een baan met een relatief hoog inkomen hebben? Misschien hechten studenten en afgestudeerden waarde aan andere 'employability' indicatoren dan degene waarover we informatie hebben en die in deze rapportage aan bod zijn gekomen.

Daarnaast is het al dan niet hebben van een vaste baan voor toekomstige afgestudeerden waarschijnlijk geen goede indicator voor'employability' in verband met de flexibilisering van de arbeidsmarkt. Het hebben van een vaste baan wordt door studenten niet meer nagestreven omdat dit niet meer de realiteit van de arbeidsmarkt is.

Het is daarom belangrijk om na te gaan welke indicatoren in de hedendaagse arbeidsmarkt het beste de'employability' van UM afgestudeerden in kaart kunnen brengen. Het lijkt in ieder geval zinvol om meer 'employability' vragen mee te nemen die ingaan op een levenlang leren (productiever worden), en de eigen perceptie als het gaat om het verkrijgen van een vergelijkbare baan indien men onverwacht op zoek zou moeten naar een (andere) baan. De UM leidt haar studenten immers niet alleen op om zo snel mogelijk na afstuderen een baan te vinden, maar ook om te zorgen voor continue groei en aanpassingsmogelijkheden (Bastiaens \& Muijsers 2016). Deze duurzame insteek strookt met verschillende gangbare invullingen van het concept 'employability', waarin gesteld wordt dat het niet alleen gaat om het verkrijgen van een baan, maar ook om (blijvende) baantevredenheid en ontwikkelmogelijkheden. Vaak zal dit betekenen dat men niet een levenlang in dezelfde functie bij dezelfde werkgever blijft, maar dat men op verschillende momenten in de loopbaan 'mobiel' zal zijn. Investeringen in iemands employability eindigen dus niet bij het behalen van een diploma: ook dit is iets waar opleidingen hun studenten van bewust dienen te maken.

In deze studie is inzicht verkregen in diverse belangrijke determinanten van 'employability'. We hebben gezien dat persoonskenmerken en persoonlijkheid een rol spelen in het verklaren van iemands 'employability'. Ook bleek dat afgestudeerden van bepaalde opleidingen meer 'employable' zijn dan andere. Het is echter nog onduidelijk waar dit 
precies aan ligt. Dit kan allereerst het gevolg zijn van het feit dat opleidingen verschillende kennis en vaardigheden aanleren en dat aan sommige competenties een grotere behoefte is op de arbeidsmarkt dan aan andere. Daarnaast suggereert de literatuur dat stages en werkervaring tijdens de opleiding positief kunnen bijdragen aan 'employability' maar deze aspecten zijn niet opgenomen in de vragenlijsten die binnen deze studie gebruikt zijn. Slechts in één jaar, 2014, is vijf jaar na afstuderen aan afgestudeerden gevraagd of zij tijdens hun studie een stage gelopen hebben. We hebben bekeken of er voor dit ene jaar een significante relatie was tussen een stage en de 'employability' indicatoren. Uit deze analyses bleek dat een stage positief gerelateerd is aan de kans op een baan binnen het vakgebied. Het zou voor toekomstig onderzoek nuttig zijn als er meer potentiële determinaten opgenomen worden in de vragenlijsten.

Voor nu kan op basis van de literatuur het volgende advies gegeven worden ${ }^{16}$ :

1. Bied studenten de mogelijkheid om praktijk-/werkervaring op te doen, bijvoorbeeld door externe stages op te nemen in het programma. Dit vereist goede netwerken tussen onderwijs en werkveld.

2. Betrek werkgevers bij de ontwikkeling van het curriculum én bij de daadwerkelijke uitvoering van het onderwijs, bijvoorbeeld door gastdocenten in te zetten

3. Maak loopbaan- en arbeidsmarktoriëntatie onderdeel van het curriculum. Investeer in kennis over de arbeidsmarkt (hoe ziet de beroepenstructuur er uit, waar liggen de kansen) en over de conventies op de arbeidsmarkt (hoe dient men zich te profileren/ gedragen).

De UM lijkt, in het kader van 'employability' al flinke stappen in de goede richting te zetten door haar onderwijs meer competentiegericht op te zetten. Het zou in deze context waardevol zijn om studenten en afgestudeerden te vragen naar hun competentieniveau met betrekking tot de voor hun opleiding belangrijkste competenties. Op die manier kan onderzocht worden of de verschillende interventies inderdaad bijdragen aan een toename in het competentieniveau en de bewustwording. Vervolgens kan onderzocht worden of het competentieniveau samenhangt met 'employability' indicatoren. Onderzoek onder werkgevers kan vervolgens inzicht geven in de manier waarop werkgevers competenties en eigenschappen van afgestudeerden en studierichtingen tegenover elkaar afwegen.

Concluderend kan gezegd worden dat het hier gerapporteerde onderzoek een mooie eerste stap is voor het in kaart brengen en verklaren van de 'employability' van UM afgestudeerden. Door alle ontwikkelingen op het gebied van 'employability' binnen de UM goed te volgen kan niet alleen een mooie bijdrage geleverd worden aan de'employability' van haar studenten en aan haar onderwijs in het algemeen, maar ook aan empirisch onderzoek op het gebied van de rol van het hoger onderwijs in de 'employability' van afgestudeerden.

16 Mommers et al. (2017) onderscheiden deze drie empirisch onderbouwde 'employabilitybevorderende maatregelen' op basis van de literatuur. 



\section{LITERATUUR}

Allen, J., Breugel, G. van, Coenen, J., Fouarge, D., Meng, C., Ramaekers, G., Dijk, J. van \& Venhorst, V. (2009). Afgestudeerden van het hbo tijdens een crisis: geen verloren generatie. Den Haag: HBOraad.

Allen, J. \& Coenen, J. (2011). Employability and mobility of bachelor graduates in The Netherlands. In H. Schomburg \& U. Teichler (Red.), Employability and mobility of bachelor graduates in Europe (pp.171-183). Rotterdam: Springer.

Bastiaens, E. \& Muijsers (2016). Integrated Strategy for Employability

Borghans, Fouarge en de Grip (2011) Een leven lang leren in Nederland, ROA-R-2011/5

Brown, P., Hesketh, A., \& Wiliams, S. (2003). Employability in a knowledge-driven economy. Journal of education and work, 16(2), 107-126.

CBS (2016) Gelijk loon voor gelijk werk? Banen en lonen bij de overheid en bedrijfsleven, 2014

Cranmer, S. (2006). Enhancing graduate employability: best intentions and mixed outcomes. Studies in Higher Education, 31(2), 169-184.

Dacre Pool, L., \& Sewell, P. (2007). The key to employability: developing a practical model of graduate employability. Education + Training, 49(4), 277-289.

Firpo, S., Carvalho, S., \& Pieri, R. (2016). Using occupational structure to measure employability with an application to the Brazilian labor market. Journal of Economic Inequality, 14(1), 1-19.

Fugate, M., \& Kinicki, A. (2008). A dispositional approach to employability: Development of a measure and test of implications for employee reactions to organizational change. Journal of Occupational and Organizational Psychology, 81(3), 503-527.

Gaalen, R.V., Goudswaard, A., Sanders, J., \& Smits, W. (2013). Dynamiek op de Nederlandse arbeidsmarkt: de focus op flexibilisering. Centraal Bureau voor de statistiek.

Golsteyn, B. H., Grönqvist, H., \& Lindahl, L. (2014). Adolescent time preferences predict lifetime outcomes. The Economic Journal, 124(580), F739-F761.

Grip, A., Loo, J., \& Sanders, J. (2004). The industry employability index: Taking account of supply and demand characteristics. International Labour Review, 143(3), 211-233.

Harvey, L. (2001). Defining and measuring employability. Quality in higher education, 7(2), 97-109.

Hillage, J. \& Pollard, E. (1998). Employability: Developing a Framework for Policy Analysis. London: DFEE.

Lee, S., \& Ohtake, F. (2012). The Effect of Personality Traits and Behavioral Characteristics on Schooling, Earnings and Career Promotion. Journal of Behavioral Economics and Finance, 5, 231238.

Lim, H. (2010). Predicting low employability graduates: The case of Universiti Utara Malaysia. The Singapore Economic Review, 55(3), 523-535. 
Mason, G., Williams, G., \& Cranmer, S. (2009). Employability skills initiatives in higher education: what effects do they have on graduate labour market outcomes? Education Economics, 17(1), 1-30.

Mommers, A., Künn-Nelen, A. \& Van Eldert, P. (2017). Employability: Literatuurstudie naar theorie en empirie, ROA-R-2017/2.

Raemdonck, I., Tillema, H., de Grip, A., Valcke, M., \& Segers, M. (2012). Does self-directedness in learning and careers predict the employability of low-qualified employees?. Vocations and Learning, 5(2), 137-151.

ROA (2016). Maastricht University graduate surveys 2016. ROA-F-2016/1.

ROA (2016b). Schoolverlaters tussen onderwijs en arbeidsmarkt 2015. ROA-R-2016/2.

Smith, C., Ferns, S., \& Russell, L. (2014). Conceptualising and measuring 'employability' - lessons from a National OLT Project. ACEN National Conference, Tweed Heads.

Smith, J., McKnight, A., \& Naylor, R. (2000). Graduate employability: policy and performance in higher education in the UK. The Economic Journal, 110(464), 382-411.

Yorke, M. (2006). Employability in higher education: What it is what it is not. In M. Yorke (Red.), Learning and employability. New York: Learning and Teaching Support Network. 
BIJLAGE 


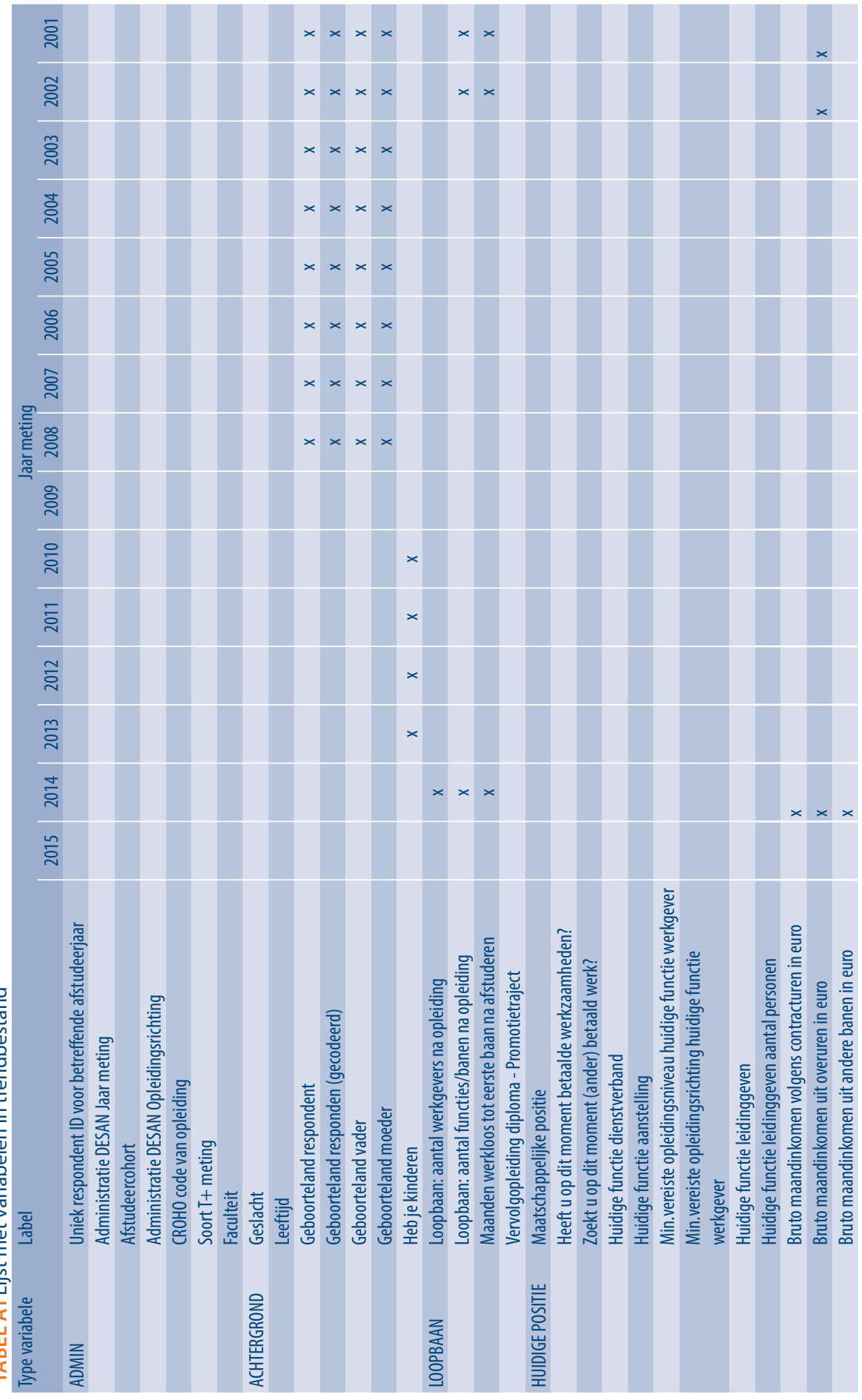




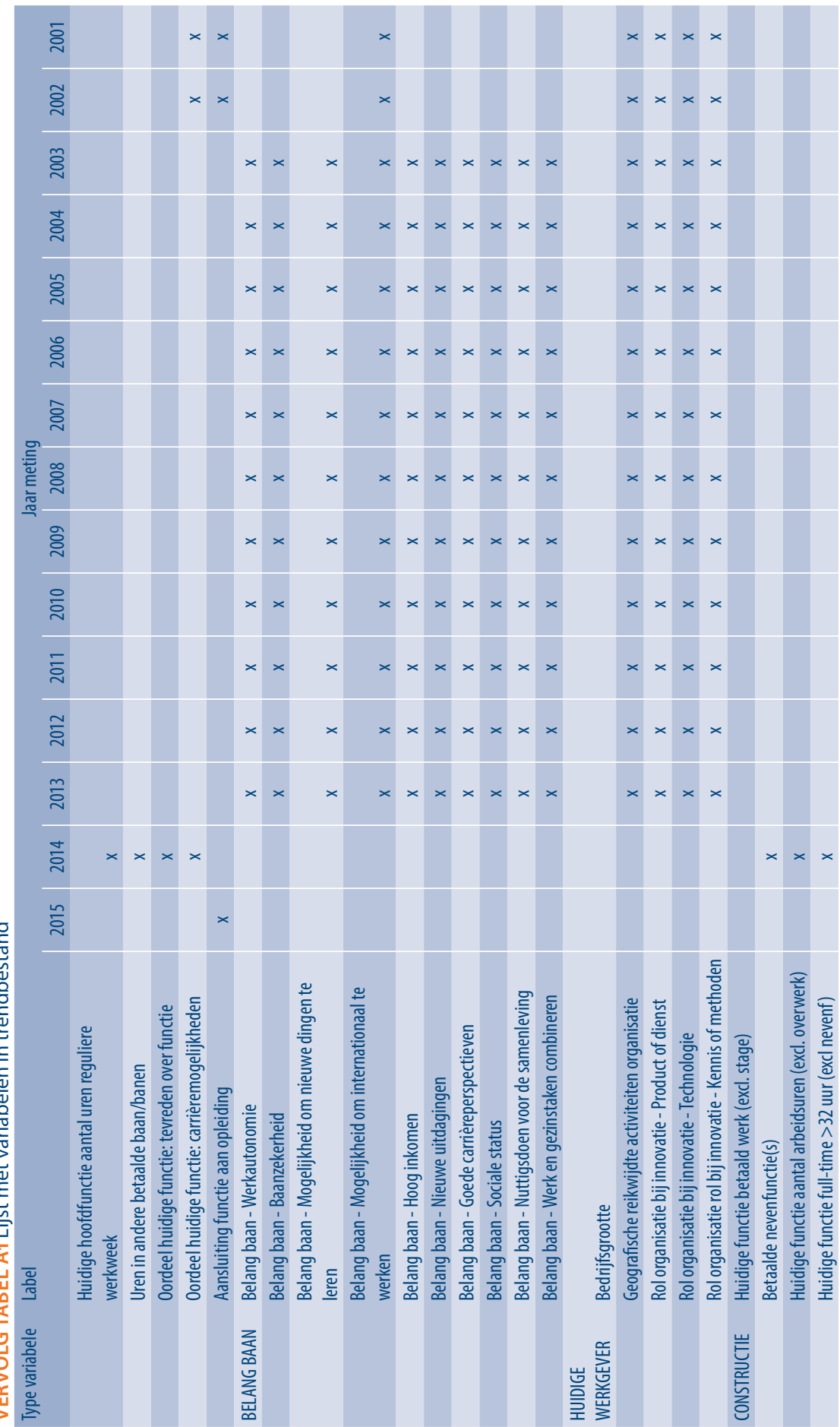




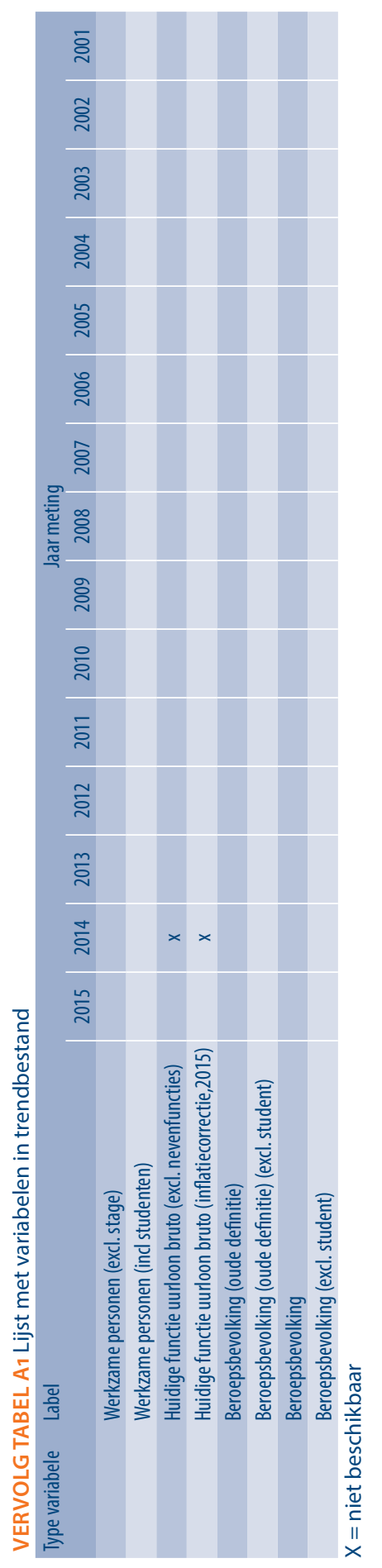

64 BIJLAGE 


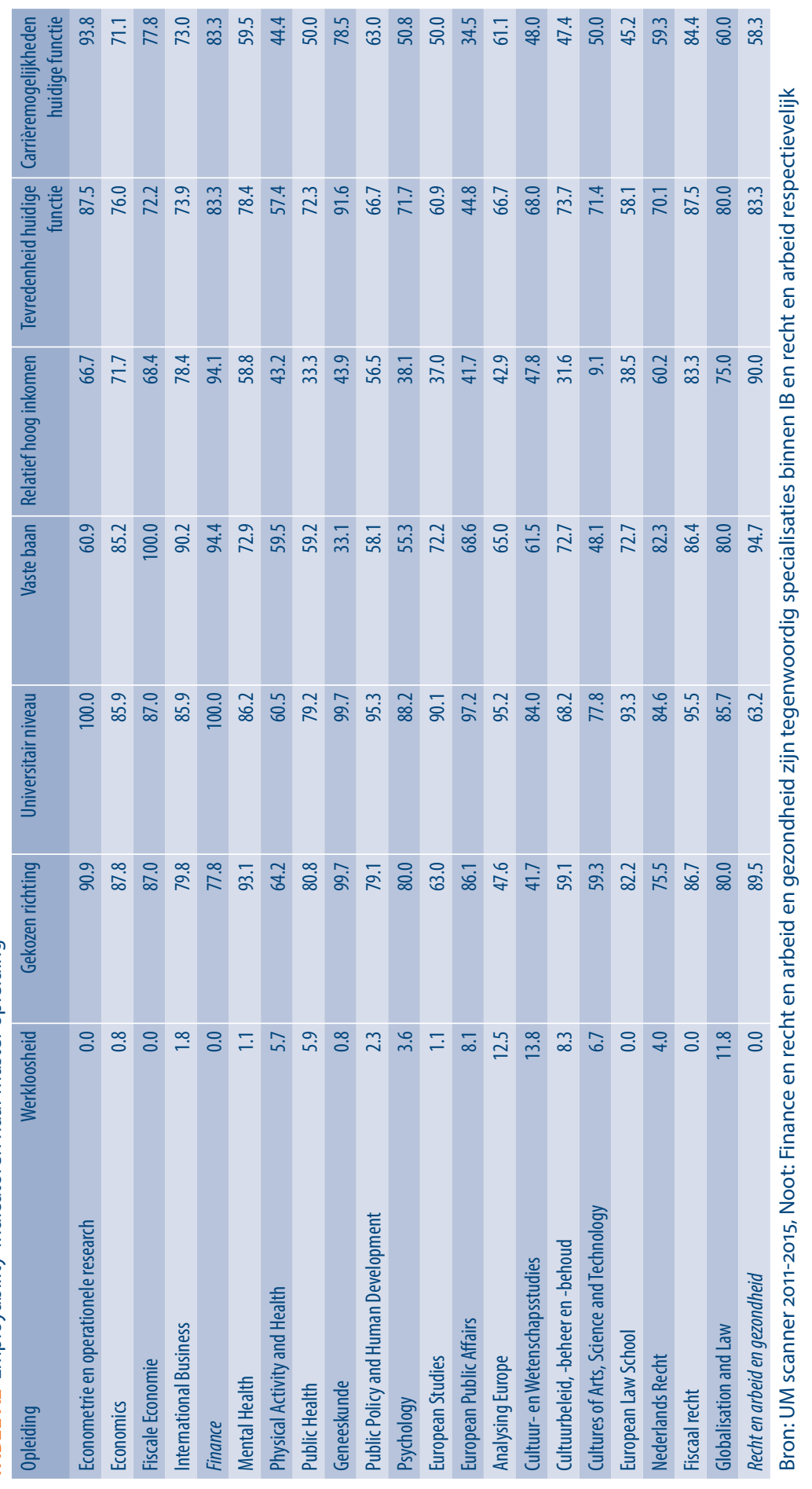


